San Jose State University

SJSU ScholarWorks

Master's Theses

Master's Theses and Graduate Research

Spring 2010

\title{
Habitat Conditions and Steelhead Abundance and Growth in a California Lagoon
}

Kristine Ann Atkinson

San Jose State University

Follow this and additional works at: https://scholarworks.sjsu.edu/etd_theses

\section{Recommended Citation}

Atkinson, Kristine Ann, "Habitat Conditions and Steelhead Abundance and Growth in a California Lagoon" (2010). Master's Theses. 3746.

DOI: https://doi.org/10.31979/etd.x32c-zndy

https://scholarworks.sjsu.edu/etd_theses/3746

This Thesis is brought to you for free and open access by the Master's Theses and Graduate Research at SJSU ScholarWorks. It has been accepted for inclusion in Master's Theses by an authorized administrator of SJSU ScholarWorks. For more information, please contact scholarworks@sjsu.edu. 


\title{
HABITAT CONDITIONS AND STEELHEAD ABUNDANCE AND GROWTH IN A
}

\section{CALIFORNIA LAGOON}

\author{
A Thesis \\ Presented to \\ The Faculty of the Department of Biology \\ San Jose State University \\ In Partial Fulfillment \\ of the Requirements for the Degree \\ Master of Science
}

by

Kristine A. Atkinson

May 2010 
(C) 2010

Kristine A. Atkinson

ALL RIGHTS RESERVED 
The Designated Thesis Committee Approves the Thesis Titled

\section{HABITAT CONDITIONS AND STEELHEAD ABUNDANCE AND GROWTH IN A CALIFORNIA LAGOON}

by

Kristine A. Atkinson

\section{APPROVED FOR THE DEPARTMENT OF BIOLOGY \\ SAN JOSE STATE UNIVERSITY}

May 2010
Dr. Jerry Smith
Department of Biology
Dr. Susan Lambrecht
Department of Biology
Dr. Sean Hayes
NOAA Fisheries 


\section{ABSTRACT \\ HABITAT CONDITIONS AND STEELHEAD ABUNDANCE AND GROWTH IN A CALIFORNIA LAGOON}

by Kristine A. Atkinson

To better understand the temporal and spatial relationships of water quality parameters, as well as steelhead (Oncorhynchus mykiss) habitat use and growth in San Gregorio Creek estuary / lagoon, water quality and steelhead at San Gregorio Creek estuary / lagoon were studied over a period of two years. During both years, there was above-average rainfall, and during the dry seasons of both years the lagoon was repeatedly artificially breached. In spite of the breaching, variations in growth and population size relative to variable sandbar dynamics were measured both within and between years. Data showed that repeated artificial breaching of the sandbar prevented complete destratification, causing hot (up to $29.5^{\circ} \mathrm{C}$ ) and hypoxic / anoxic conditions at the bottom of the water column. Nevertheless, steelhead that reared in the lagoon in both 2005 and 2006 were abundant and grew substantially larger than those in two stream reaches. Coho (O. kisutch) did not rear in the lagoon, but passed through as smolts in spring 2006. Sizes of juveniles in the lagoon were more related to time spent in the lagoon than to their age. In 2005 the estimated steelhead population declined $15 \%$ from 2,365 \pm 598_to $2,005 \pm 715$ from July to October. The 2006 population decreased substantially from $2,802 \pm 354$ to $1,373 \pm 610$, and age $0+$ grew slower, possibly due to impacts of breaching. A majority $(55-64 \%)$ of a sample $(n=22)$ of adult steelhead had reared in the lagoon. Most of the remaining adults and most spring smolts reared 2 years in the stream. 


\section{ACKNOWLEDGEMENTS}

I received support from numerous volunteers who assisted one or more days in the field. These volunteers included friends, San Jose State University (SJSU) students, California Department of Fish and Game (CDFG) staff, and San Mateo County Farm Bureau staff.

Thank you goes to all volunteers for their field assistance, including friends John Campbell, Susan Cummins, Dr. Jill Harrison, Lynn Thorenson, and Minja Peabody, as well as to SJSU students, including Carole Foster and her son, Nate Foster, as well as students Julie and Joel Casagrande, Jae Abel, and students from the SJSU Fisheries Management classes (Spring 2006 and 2008). I am grateful for the field assistance and volunteers provided by CDFG's Patricia Anderson, Lisa Morton, Matt Michie, Jennifer Nelson, and Kevan Urquhart. Additionally, I am appreciative of the information provided by avid angler and Farm Bureau Director, Tim Frahm, on the status of the sandbar at the lagoon.

A thank you goes to my graduate advisor, Dr. Jerry Smith, who assisted in providing resources and volunteers, and who also provided thoughtful comments in his review of this manuscript. Additionally, my thanks go to thesis committee members SJSU Professor Dr. Susan Lambrecht and NOAA Fisheries researcher Dr. Sean Hayes who were also instrumental in their reviews of this document.

Finally, a thank you goes to my friends, family, and colleagues for their support and encouragement to complete this project. 


\section{Table of Contents}

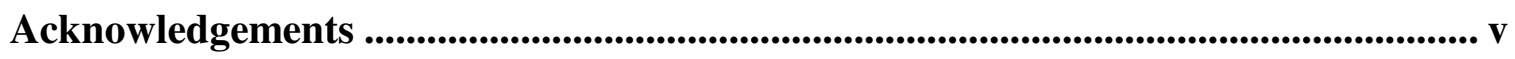

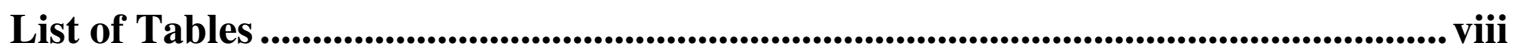

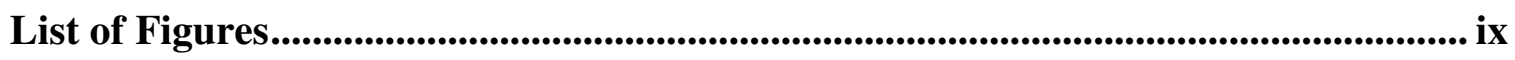

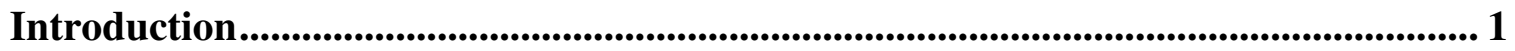

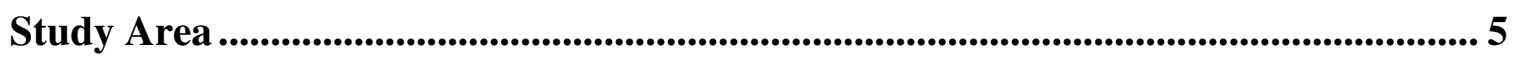

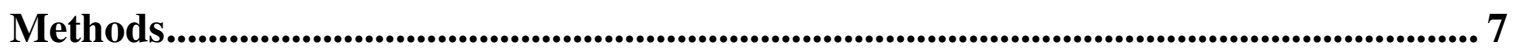

Water Quality And Stream Flow Determination ................................................... 7

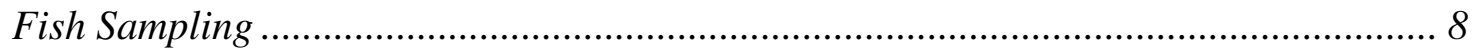

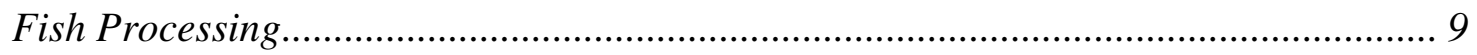

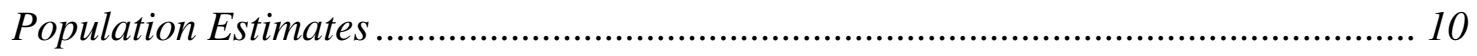

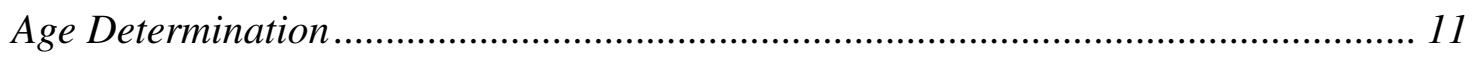

Life History Patterns........................................................................................ 12

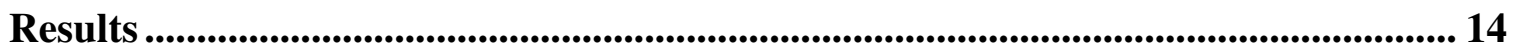

Flow (Wet And Dry Seasons of 2004-2005) ............................................................... 14

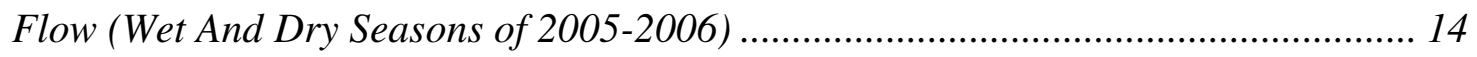

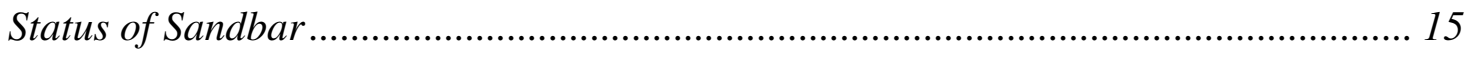

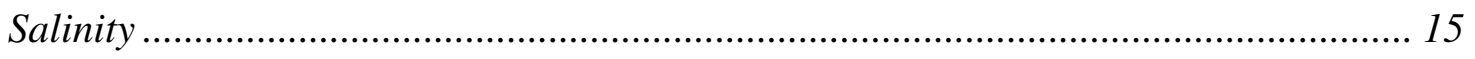

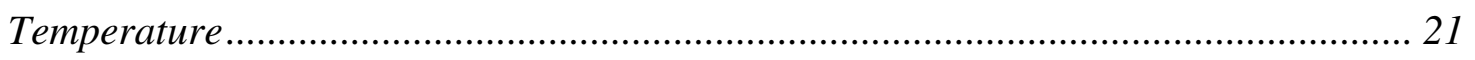

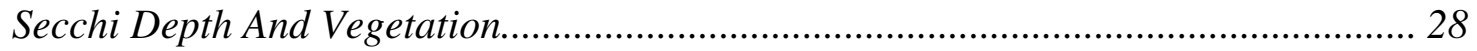

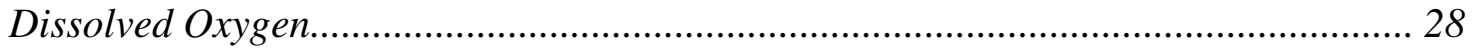

Lagoon / Estuary Utilization by Fishes .................................................................. 37

Summer / Fall Steelhead Rearing in 2005 .......................................................... 37

Winter / Spring Steelhead Rearing and Smolt Out-Migration in 2006........................ 39

Summer / Fall Steelhead Rearing in 2006 .............................................................. 40

Spring Steelhead Rearing and Smolt Out-Migration in 2008.................................... 41

Spatial Patterns of Steelhead Lagoon Use in 2005 ................................................. 42

Rearing Strategies of Successful Adult Steelhead Captured in April 2008 ................. 43 


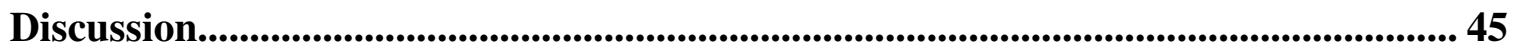

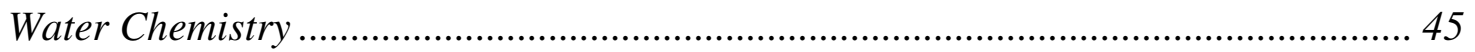

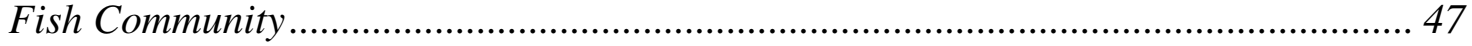

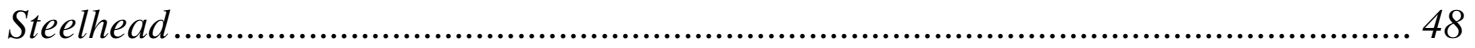

Patterns of Lagoon Utilization (Years 2005-2006 and April 2008) ........................... 53

Steelhead Life Histories at San Gregorio Creek Watershed ...................................... 55

Steelhead Population Over Time at San Gregorio Creek Estuary/Lagoon.................. 55

Steelhead Physiology and the Importance of Lagoons .............................................. 56

Management Implications: Artificial Breaching …................................................................57

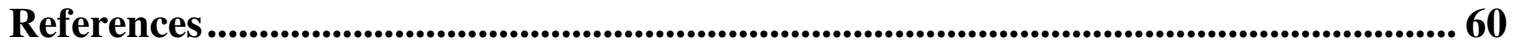




\section{List of Tables}

\section{Table}

1. Timeline of sandbar closure in years 2005 and 2006 in San Gregorio Creek lagoon, San Mateo County...............................................67

2. Back-calculation of standard lengths $(\mathrm{mm})$ at last freshwater annulus from successful adult steelhead collected on April 18, 2008 in San Gregorio Creek lagoon, San Mateo County....

3. Standard length ( $\mathrm{mm})$ of steelhead captured at Alpine Creek, San Gregorio Creek, and San Gregorio Creek lagoon in 2005-2006, as well as the mean back-calculated standard length at last freshwater annulus from successful adult steelhead collected on April 18, 2006 in San Gregorio Creek lagoon. All locations are within the San Gregorio Creek watershed, San Mateo County 


\section{List of Figures}

Figure

1. Fish sampling locations in the San Gregorio Creek watershed, San Mateo

County.............................................................70

2. Water quality sampling locations at San Gregorio Creek lagoon, San Mateo

County........................................................ 71

3. Fish seining locations at San Gregorio Creek lagoon, San Mateo County........72

4. Example of interpretation of a steelhead scale from age $2+$ smolt...............73

5. Flows and United States Geological Survey percentiles at the Stage Road bridge crossing during the years of (a) 2005 and (b) 2006 at San Gregorio Creek, San Mateo County....

6. Observed Highway 1 gage height in year 2005 (a) and 2006 (b) at San Gregorio Creek lagoon, San Mateo County. Gage was arbitrarily placed and not surveyed.

7. Salinity (ppt) at Stations \#3, 6, 9, and 12 on (a) June 17, (b) July 15, and (c) July 29, 2005 at San Gregorio Creek lagoon, San Mateo County...

8. Salinity (ppt) at Stations \#3, 6, 9, and 12 on (a) August 04, (b) August 12, and (c) September 09, 2005 in San Gregorio Creek lagoon, San Mateo County

9. Salinity (ppt) at Stations \#3, 6, 9, and 12 on (a) September 24,

(b) October 14, and (c) October 29, 2005 in San Gregorio Creek lagoon,

San Mateo County

10. Salinity (ppt) at Stations \#3, 6, 9, and 12 on (a) November 18 and (b) December 02, 2005 in San Gregorio Creek lagoon, San Mateo County

11. Salinity (ppt) at Station \#3 on (a) February 16, (b) March 16, and (c) May 19, 2006 in San Gregorio Creek lagoon, San Mateo County...

12. Salinity (ppt) at Stations \#3, 6, 9, and 12 on (a) June 16, (b) July 14, and (c) August 11, 2006 in San Gregorio Creek lagoon, San Mateo County 
13. Salinity (ppt) at Stations \#3, 6, 9, and 12 on (a) August 18, (b) September 08, and (c) September 15, 2006 in San Gregorio Creek lagoon, San Mateo County....

14. Salinity (ppt) at Stations \#3, 6, 9, and 12 on (a) October 05, (b) November 02, and (c) November 30, 2006 in San Gregorio Creek lagoon, San Mateo County....

15. Salinity (ppt) at Station \#3 April 18, 2008 in San Gregorio Creek lagoon, San Mateo County...

16. Temperature $\left({ }^{\circ} \mathrm{C}\right)$ at Stations \#3, 6, 9, and 12 on (a) June 17 and (b) July 15, 2005 in San Gregorio Creek lagoon, San Mateo County. .

17. Temperature $\left({ }^{\circ} \mathrm{C}\right)$ at Stations \#3, 6, 9, and 12 on (a) August 04, (b) August 12, and (c) September 09, 2005 in San Gregorio Creek lagoon, San Mateo

County .86

18. Temperature $\left({ }^{\circ} \mathrm{C}\right)$ at Stations \#3, 6, 9, and 12 on (a) September 24, (b) October 14, and (c) October 29, 2005 in San Gregorio Creek lagoon, San Mateo County....

19. Temperature $\left({ }^{\circ} \mathrm{C}\right)$ at Stations \#3, 6, 9, and 12 on (a) November 18 and (b) December 02, 2005 in San Gregorio Creek lagoon, San Mateo County...

20. Temperature $\left({ }^{\circ} \mathrm{C}\right)$ at Station \#3 on (a) February 16, (b) March 16, and (c) May 19, 2006 in San Gregorio Creek lagoon, San Mateo County....

21. Temperature $\left({ }^{\circ} \mathrm{C}\right)$ at Stations \#3, 6, 9, and 12 on (a) June 17, (b) July 14, and (c) August 11, 2006 in San Gregorio Creek lagoon, San Mateo County.....90

22. Temperature $\left({ }^{\circ} \mathrm{C}\right)$ at Stations \#3, 6, 9, and 12 on (a) August 18, (b) September 08, and (c) September 15, 2006 in San Gregorio Creek lagoon, San Mateo County...

23. Temperature $\left({ }^{\circ} \mathrm{C}\right)$ at Stations \#3, 6, 9, and 12 on (a) October 05, (b) November 02, and (c) November 30, 2006 in San Gregorio Creek lagoon, San Mateo County....

24. Temperature $\left({ }^{\circ} \mathrm{C}\right)$ at Station \#3 April 18, 2008 in San Gregorio Creek lagoon, San Mateo County. 
25. Mean values of secchi depth measurements at Station \#3 during the summer and fall of (a) 2005 and (b) 2006 at San Gregorio Creek lagoon, San Mateo County. Water column depth is plotted only where secchi depth was determined to be greater than water column depth.

26. Dissolved oxygen (mg/L) at Stations \#3, 6, 9, and 12 on (a) June 17, (b) July 15, and (c) July 29, 2005 in San Gregorio Creek lagoon, San Mateo County.....

27. Dissolved oxygen (mg/L) at Stations \#3, 6, 9, and 12 on (a) August 04, (b) August 12, and (c) September 09, 2005 in San Gregorio Creek lagoon, San Mateo County. .96

28. Dissolved oxygen (mg/L) at Stations \#3, 6, 9, and 12 on (a) September 24, (b) October 14, and (c) October 29, 2005 in San Gregorio Creek lagoon, San Mateo County.

29. Dissolved oxygen (mg/L) at Stations \#3, 6, 9, and 12 on (a) November 18 and (b) December 02, 2005 in San Gregorio Creek lagoon, San Mateo County.....

30. Dissolved oxygen (mg/L) at Station \#3 on (a) February 16, (b) March 16, and (c) April 13, 2006 in San Gregorio Creek lagoon, San Mateo County

31. Dissolved oxygen (mg/L) at Stations \#3, 6, 9, and 12 on (a) June 16 and (b) July 14, 2006 in San Gregorio Creek lagoon, San Mateo County 100

32. Dissolved oxygen (mg/L) at Stations \#3, 6, 9, and 12 (a) in the morning and at Stations \#3 and \#6 in the (b) late morning on August 16, 2005 in San Gregorio Creek lagoon, San Mateo County

33. Dissolved oxygen (mg/L) at Stations \#3, 6, 9, and 12 on (a) August 18, (b) September 08, and (c) September 15, 2006 in San Gregorio Creek lagoon, San Mateo County.

34. Dissolved oxygen (mg/L) at Stations \#3, 6, 9, and 12 on (a) October 05, (b) November 02, and (c) November 30, 2006 in San Gregorio Creek lagoon, San Mateo County....

35. Dissolved oxygen (mg/L) at Station \#3 April 18, 2008 in San Gregorio Creek lagoon, San Mateo County. 104 
36. Population estimates and confidence intervals of steelhead from the period of July 01, 2005 to November 03, 2006 in San Gregorio Creek lagoon, San Mateo County

37. Standard length ( $\mathrm{mm}$ ) of steelhead of different ages on (a) July 01 and (b) October 27, 2005 at San Gregorio Creek lagoon, San Mateo County

38. Mean standard lengths $(\mathrm{mm})$ of steelhead of different ages from the period of July 01 to October 27, 2005 in San Gregorio Creek lagoon, San Mateo County.

39. Standard length ( $\mathrm{mm}$ ) of steelhead of different ages on November 15, 2005 at (a) San Gregorio Creek and (b) Alpine Creek. Both stations are located within the San Gregorio Creek watershed, San Mateo County 108

40. Standard length ( $\mathrm{mm}$ ) of steelhead of different ages on (a) February 16 and (b) March 16, 2006 in San Gregorio Creek lagoon, San Mateo County. All of the steelhead captured were smolts.

41. Standard length ( $\mathrm{mm}$ ) of juvenile steelhead of different ages on (a) April 28, 2006 and (b) May 19, 2006 in San Gregorio Creek lagoon, San Mateo County. Additionally, one jack (not in figure) was captured by hand on April 28, 2006.

42. Standard length ( $\mathrm{mm}$ ) of steelhead of different ages on June 16, 2006 in San Gregorio Creek lagoon, San Mateo County.

43. Mean standard lengths $(\mathrm{mm})$ of juvenile steelhead of different ages from the period of February 16 to November 03, 2006 in San Gregorio Creek lagoon, San Mateo County Additionally, one jack (not in figure) was captured by hand on April 28, 2006

44. Standard length ( $\mathrm{mm}$ ) of steelhead of different ages on (a) July 19, 2006 and on (b) November 03, 2006 in San Gregorio Creek lagoon, San Mateo County.

45. Standard length ( $\mathrm{mm}$ ) of juvenile steelhead of different on April 18, 2008 in San Gregorio Creek lagoon, San Mateo County. Also, 23 adult steelhead (not in figure) were captured on this date. Nearly all of the juvenile steelhead captured were smolts 
46. Total catch of steelhead, two seine hauls per station, from the period of July 01 to October 27, 2005 at stations located downstream ("Lower Lagoon") and upstream ("Middle Lagoon") within San Gregorio Creek lagoon, San Mateo County. For upstream sampling, the Middle Lagoon (I) Station was seined on July 01 and August 15 before it flooded with backwater caused by lagoon formation. After Middle Lagoon (I) Station flooded, Middle Lagoon (II) Station was seined (on September 20, October 18, and October 27, 2005) for upstream lagoon data....

47. Mean standard lengths ( $\mathrm{mm}$ ) of total steelhead measured from the period of July 01 to October 27, 2005 in stations located downstream ("Lower Lagoon") and upstream ("Middle Lagoon") within San Gregorio Creek lagoon, San Mateo County...

48. Standard length (mm) of steelhead of different ages at (a) downstream ("Lower Lagoon") and (b) upstream stations ("Middle Lagoon") on August 15, 2005 in San Gregorio Creek lagoon, San Mateo County....

49. Standard length ( $\mathrm{mm}$ ) of steelhead of different ages at (a) downstream ("Lower Lagoon") and (b) upstream stations ("Middle Lagoon") on October 27, 2005 in San Gregorio Creek lagoon, San Mateo County.... 


\section{Introduction}

Steelhead (Oncorhynchus mykiss) were once native to Siberia and Pacific Coast streams, ranging in North America from the Kuskokwim River in Alaska south to streams in Baja California, Mexico. In addition to adapting to a broad range of latitudes, steelhead have variable growth and flexible life history strategies (Moyle 2002). Despite their flexibility, their abundance has substantially declined in areas of the West Coast of the United States. Currently in California, populations are listed under the Federal Endangered Species Act as “Threatened” in four Distinct Population Segments (DPS) and as "Endangered" in the southernmost DPS.

In order to aid the survival of this species, many efforts have been made to understand the interaction of steelhead with ecological factors. For steelhead trout and other fish species, estuary / lagoon habitat has been documented to be important for rearing (Shapovalov and Taft 1954; Johnson et al. 1986; Smith 1990; Zedonis 1992; McMahon and Holtby 1992; Busby and Barnhart 1995; Bond 2006; Hayes et al. 2008). Smith (1990), Cannata (1998), Bond (2006), Hanson (2008) and Hayes et al. (2008) determined that juvenile steelhead in lagoons can grow substantially faster than they do in riverine habitat, producing substantially larger smolts. Larger steelhead smolts are more likely to survive to return as adults (Ward et al. 1989; Smith 1990; Tipping 1997; Bond 2006), further indicating the importance of lagoon habitat. In addition, Smith (1990), Cannata (1998), Bond (2006), and Hayes et al. (2008) determined that steelhead that rear in lagoons smolt at an earlier age than most stream fish. Further, Hanson (2008) observed differences in size and age at downstream migration for steelhead streams in 
Central California with and without estuaries / lagoons, with fish tending to migrate at younger ages and smaller sizes in systems with lagoons, suggesting strong local adaptation to use this critical habitat when present.

The importance of estuarine rearing for steelhead was further demonstrated by Bond (2006) in his study at the Scott Creek watershed, Santa Cruz County. He determined that $85 \%$ of the returning adult steelhead had reared in the estuary / lagoon as age $0+$ or $1+$ of despite the fact that these individuals comprised only $8 \%-48 \%$ of the juvenile steelhead production in that watershed.

Lagoons are known to be important for rearing because they can provide large quantities of food (macroinvertebrates), cover (i.e., depth, aquatic vegetation, and overhanging banks), and backwater habitat. In addition, estuary conditions consisting of a vertically stratified water column (less dense freshwater layer on top of denser saltwater layer) provide a "transition zone" for salmonids to gradually physiologically adapt for emigration and immigration into marine and freshwater environments (Hoar 1976; Healey 1982). Furthermore, juvenile salmonids that were deprived of an estuary residence suffered from higher physiological stress during saltwater entrance than those that had longer estuary residence times (MacDonald et al. 1988).

Hydrological and water chemistry conditions at central California lagoons are known to vary spatially and seasonally (Pritchard 1952; Smith 1990; Robinson 1993; Cannata 1998; Watson et al. 2001). In small watersheds, a reduction of stream flows at the end of the rainy season, coupled with the augmentation of sand at beaches, results in the formation of sandbars at the mouths of streams. Sandbar formation dams the mouths 
of streams, creating lagoons. Newly formed lagoons typically have a vertically stratified less-dense freshwater layer on top of a denser saltwater layer (Smith 1990; Robinson 1993; Cannata 1998). As streams continue to add freshwater to the lagoon, the denser saltwater layer is pushed out first through the sandbar, destratifying the water column to a freshwater system if flows are sufficient (Smith 1990; Watson et al. 2001).

Salinity stratification has been reported to be an important factor driving the water quality of lagoons, by affecting temperature and dissolved oxygen concentrations (Smith 1990; Robinson 1993; Cannata 1998; Sloan 2006). Previous studies reported a relationship between water quality of lagoons and the abundance of macroinvertebrates (Robinson 1993) and food habits of fish (Martin 1995) at Pescadero Creek estuary / lagoon, San Mateo County. When water quality conditions were good (low to moderate temperatures and high dissolved oxygen concentrations), macroinvertebrate abundance was high, and species composition changed from marine and euryhaline species to freshwater species, depending on water column salinity (Robinson 1993). When the estuary was subject to tidal influence and salinity was high, steelhead fed more heavily on marine and euryhaline species (Martin 1995). When the lagoon became fresh after sandbar closure and salinity destratification, steelhead fed on freshwater species. Finally, Smith (1990) and Cannata (1998) reported a relationship between water quality and the growth and abundance of steelhead in estuary / lagoons, with both determining that steelhead grew faster when temperature was low to moderate and dissolved oxygen concentration high. 
Although previous studies indicate the potential importance of estuaries / lagoons as steelhead rearing habitat, there is variation among lagoons due to a variety of factors and additional studies can be useful. There is the need to better understand steelhead habitat utilization and preference, as well as the cues (environmental or genetic) that drive an individual's decision of whether to utilize certain habitat or outmigrate. In order to restore steelhead populations in their southern range, there exists the need to better understand how steelhead growth and abundance in watersheds can be maximized and how various habitat features can be enhanced.

The purpose of this study was to examine the temporal and spatial relationships of water quality parameters as well as steelhead habitat use and growth in San Gregorio Creek estuary / lagoon. Ideally, a year of closed lagoon should be compared with a year of open lagoon conditions. However, in both years of my study the sandbar was repeatedly artificially breached. In spite of this, I was able to measure variations in growth and population size relative to variable sandbar dynamics both within and between years. In this study I investigated water quality conditions and steelhead abundance, growth, and habitat utilization within the estuary / lagoon. I then compared steelhead size and age to that of two riverine reaches, one in the lower watershed and one in the upper watershed. By the analysis of fish scales from the lagoon and stream juvenile fish, and from smolts and adults, I then defined the life histories in the San Gregorio Creek watershed in terms of which habitats were being used for rearing and the relative contribution of these habitats to adult returns. Lastly, I compared population data from in my study with previous studies at San Gregorio Creek estuary / lagoon. 


\section{Study Area}

The San Gregorio Creek Watershed, located in San Mateo County, California, is approximately $134 \mathrm{~km}^{2}\left(51.6 \mathrm{mi}^{2}\right)$ (Figure 1). This watershed originates in the Santa Cruz Mountains from elevations as high as $625 \mathrm{~m}$ and flows in a westerly direction,

draining into the Pacific Ocean. San Gregorio Creek mainstem is approximately $19.3 \mathrm{~km}$ in length, is a fourth order perennial stream and is located downstream of two major tributaries, La Honda Creek and Alpine Creek. The towns of San Gregorio and La Honda are located adjacent to the mainstem of San Gregorio Creek along Highway 84. The lower San Gregorio Creek watershed riparian corridor consists of a deciduous, overstory canopy primarily of alders (Alnus spp.), an understory dominated by willows (Salix spp.), and is surrounded mainly by cultivated farmland. The upper watershed riparian corridor is dominated by a thick overstory canopy of coastal redwoods (Sequoia sempervirens).

Before draining into the Pacific Ocean, San Gregorio Creek passes through an estuary / lagoon that is located adjacent to the intersection of Highways 84 and 1. The downstream to middle reach of the lagoon is located within San Gregorio State Beach. The upstream reach of the lagoon is located on property owned by private landowners and the Peninsula Open Space Trust. The closed lagoon has a surface area of approximately $0.02 \mathrm{~km}^{2}$ ( $\left.4.9 \mathrm{ac}\right)$ and is approximately $610 \mathrm{~m}$ (2,000 ft) long. The upstream portion of the lagoon is approximately $6 \mathrm{~m}(20 \mathrm{ft})$ wide and the downstream portion is approximately $23-30 \mathrm{~m}(75-100 \mathrm{ft})$ wide at the Highway 1 bridge. A wide summer embayment is present downstream of Highway 1 and spreads out to a much 
greater width across San Gregorio State Beach, often flooding public access to the beach from the parking lot located on the north bluff. When full, the lagoon can reach depths of $2.8 \mathrm{~m}$ at some locations. Because the channel is incised, the lagoon seldom inundates wetlands outside of the main stream channel in the reach located upstream of the Highway 1 bridge.

The United States Geologic Survey (USGS) maintains a flow gaging station just upstream of the lagoon at the Stage Road bridge crossing of San Gregorio Creek in the town of San Gregorio. USGS has been monitoring stream flow nearly continuously for more than 30 years, but the gage was not operated after September 2005. San Gregorio Creek experiences low flows during the late summer and fall, and water withdrawal occurs throughout the year. 


\section{Methods}

\section{Water Quality And Stream Flow Determination}

Sandbar status was monitored as often as possible, at intervals of three to seven days during the period of June through December of 2005 and 2006. Additionally, volunteers called and reported when they observed a change in status.

I collected water chemistry and stream flow data approximately once per week from June 17 to December 02 in 2005 and from June 16 to November 30 in 2006 . In addition, I collected water chemistry and stream flow data during the fish sampling events throughout the duration of the study, including on my one day (April 18) of fish sampling in 2008. Sampling was conducted during the morning hours when dissolved oxygen was expected to be lowest. Water chemistry during fish sampling events was usually collected only at Station \#3 near the Highway 1 bridge, while weekly water chemistry data was collected at 12 locations throughout the lagoon (Figure 2).

At each location throughout the lagoon, I determined vertical profiles of salinity, temperature, and dissolved oxygen with a YSI Model 85, YSI Inc., Yellow Springs, OH at $0.25 \mathrm{~m}$ intervals from the lagoon's surface to its bottom. I used a secchi disk to determine water clarity at each site. I measured stream flow to the lagoon with a MarshMcBirney Flo-Mate 2000, Hach Co., Loveland, Colorado, in San Gregorio Creek at Stage Road bridge, where the United States Geological Survey (USGS) stream gage was located (Figure 1). In addition to measuring flow, I utilized USGS stream gage data before it went offline at the end of September 2005. Due to lack of funding, this gage remained offline through 2006. 


\section{Fish Sampling}

In 2005, I used a beach seine which had the following dimensions: length: $32.3 \mathrm{~m}$; height: $1.8 \mathrm{~m}$; mesh size: $0.95 \mathrm{~cm}$; and bag size: $1.8 \mathrm{~m}$ x $1.8 \mathrm{~m}$. I sampled fish five times in San Gregorio Creek lagoon during the period between July 01 through October 27 in 2005. In order to assess movement within the lagoon, steelhead were sampled at two stations located in the downstream portion (adjacent to the Highway 1 bridge) of the lagoon (referred to as "Lower Lagoon Station") and at two stations located in the upstream portion (“Middle Lagoon Stations (I) and (II)”) (Figure 3). Middle Lagoon (I) was seined on July 01 and August 15 before the landing area was inundated by sandbar formation. After Middle Station (I) flooded, Middle Lagoon Station (II) was seined (on September 20, October 18, and October 27) to provide upstream lagoon data.

Steelhead were marked by clipping a small portion of a pelvic fin that corresponded to the location within the lagoon where the fish was collected, and both the downstream Lower Lagoon Station and upstream Stations were sampled on the same date. Fish population estimates of the same seining event were determined by mark / recapture either that day or after returning approximately one week later. Habitat utilization was additionally assessed by analyses of catch per unit effort at the downstream Lower Lagoon Station versus an upstream Station.

Using a Type 12B, Smith-Root, Inc., Vancouver, Washington, electrofisher, I conducted single-pass sampling of two stream reaches within the San Gregorio Creek watershed on November 15, 2005; one in the lower watershed on San Gregorio Creek, located just upstream of the Kingston Creek confluence, and one at the upper watershed 
on Alpine Creek. I then compared steelhead size and age of those two stream reaches with that of the lagoon.

In 2006, I seined seven times in San Gregorio Creek lagoon from February 16 through November 03. In order to make steelhead population estimates (and not assess movement as in year 2005), I seined only at the Lower Lagoon Station near Highway 1 which had the highest steelhead density in 2005. Steelhead were marked by clipping a small portion of their pelvic or caudal fins, and steelhead population estimates were determined by mark / recapture that day.

In 2008, I seined only on April 18 and determined a population estimate. Additionally, I collected scales from both juveniles and adult steelhead. From the juvenile data, I then compared age structure, length frequency distribution, and life history patterns with those captured in April 2006. From the adult data, I back-calculated freshwater and marine rearing patterns based upon circuli spacing and annulus position. (Figure 4).

\section{Fish Processing}

Generally, all fish captured were identified to species and measured in $5 \mathrm{~mm}$ standard length (SL) increments. At all times, care was taken to ensure that captured fish remained in healthy condition, and measures were taken to reduce handling time whenever possible. I found that the best way to keep individuals healthy was to keep them uncrowded in floating live cars, and / or in the seine itself, with sufficient depth to allow ample circulation of ambient water. 
During times when there were 200+ steelhead captured in a single seine haul, I either subsampled lengths and scales of a minimum of 100 fish (and the rest were counted and marked), or if conditions were acceptable, I measured and marked all steelhead in the one seine haul then only counted and marked individuals in further seine hauls.

Using a clean pocket knife, I collected scales from steelhead in the area just below the dorsal fin and above the lateral line so that I could later determine the age of individuals. I made sure that the knife was rinsed between samples to ensure there was no mixing of scale samples. Each scale sample was placed into individual scale (coin) envelopes and the date, location, and standard length were recorded on each envelope.

I graphed the standard length of the total steelhead measured and that from which scales were collected to ensure that the scale sample was representative during all fish sampling events.

\section{Population Estimates}

Population estimates of steelhead were calculated using the Adjusted Peterson Estimator for capture with replacement (Ricker 1975). I used the following equations for the estimated population size, variance, and $95 \%$ confidence interval:

$$
\begin{aligned}
& \text { Population Size }(\mathrm{N})=[\mathrm{M}(\mathrm{C}+1)] /(\mathrm{R}+1) \\
& \text { Variance }[\mathrm{V}(\mathrm{N})]=\left[\mathrm{M}^{2}(\mathrm{C}+1)(\mathrm{C}-\mathrm{R})\right] /\left[(\mathrm{R}+1)^{2}(\mathrm{R}+2)\right] \\
& \text { Confidence Interval }\left(\mathrm{C}_{\mathrm{I}}\right)=\mathrm{N} \pm 1.96[\mathrm{~V}(\mathrm{~N})]^{1 / 2}
\end{aligned}
$$


Where: $\mathrm{M}=$ number of marked fish; $\mathrm{C}=$ number of fish in the sample; $\mathrm{R}=$ number of marked fish in the sample.

\section{Age Determination}

Age determination of steelhead was performed by fish scale analysis. Scales were mounted between two microscope slides and the information recorded on the envelopes was transcribed onto a label for each slide. A minimum of 6 scales were mounted onto each slide to ensure there would be some readable scales. Scales that were chosen for reading were free of regeneration and were relatively symmetrical and uniform in shape. On the chosen scales, I determined the steelhead's age by counting the number of annuli (Figure 4). For quality control / quality assurance purposes, I analyzed each slide a minimum of two times and excluded slides which contained only poor quality scales.

I determined the annuli by first acknowledging the time of year the steelhead was captured and recognizing the seasonal growth pattern for a lagoon fish to be a cessation of growth due to poor feeding conditions in the winter due to substantial decrease in temperature and increase in turbidity. For a stream fish, I recognized the seasonal growth pattern to be a cessation of growth in the late summer due to poor feeding conditions associated with low stream flows (McCarthy et al. 2009). This change in growth was assessed by a truncation of circuli (termed "crossing over") due to lateral scale erosion as the fish lost weight and girth. I then determined the annulus to be the first circulus after the "crossing over" event. Scales collected during February and March seining events, often had annuli that were either located at the very edge of the anterior field or were not 
yet observed. For scales collected in February and March that had not yet exhibited an annulus near the end of the scale, I assigned an annulus under the assumption that the fish was in the process of developing annulus.

\section{Life History Patterns}

In order to define age and growth rearing patterns of steelhead within the San Gregorio Creek watershed, as well as assess the percentage of the adult steelhead population that had reared a substantial amount of time in the lagoon, I analyzed scales from adults $(\mathrm{n}=22)$ captured in San Gregorio Creek lagoon on April 18, 2008.

Additionally, I analyzed the scales of steelhead smolts captured in the lagoon in April 2006 and 2008 to compare the age structure, length frequency distribution, and growth patterns and thus determined whether there were differences in rearing, growth, and outmigration patterns between the wet and dry year.

Based on the principle that steelhead exhibit indeterminate growth and that there is a strong relationship between standard length and scale size, I back-calculated the size of the steelhead at ocean entry from the adults. I then assessed the number of years each adult steelhead had reared as a juvenile in the following habitats: stream habitat only; both the stream and lagoon habitat; and in the lagoon habitat only.

I used the following equation to back-calculate the size of steelhead at previous annuli:

Standard Length $(\mathrm{SL})=\mathrm{mS}_{\mathrm{R}}+\mathrm{b}$ 
Where $S_{R}=$ scale radius; $b=$ standard length at which steelhead begin forming scales. For simplicity of doing the calculations, I set the size at which steelhead begin forming scales to $27.5 \mathrm{~mm}$ which is the mean of the size range (25-30 $\mathrm{mm} \mathrm{SL})$ in which this is known to occur (Carlander 1969). 


\section{Results}

Flow (Wet And Dry Seasons of 2004-2005)

San Gregorio Creek daily mean discharge values measured at the USGS Gage were nearly always within the 75 th to 95 th percentile range during the wet season of 2004-2005 (Figure 5a) (United State Geological Survey 2005). Although rain fell in October 2004, high flow events most frequently occurred within the period of mid December 2004 through mid April 2005 (Figure 5a). The maximum discharge [16.4 cms (579 cfs)] of the rainy season occurred on March 22, 2005.

During the dry season, daily mean discharge values decreased but continued to be within the 75th to 95th percentile range until the end of September 2005. Flows were fairly consistent from the period of September through November due to delayed fall rains and increased slightly in December 2005. Despite the consistent discharge, percentile steadily decreased to within the 20th percentile and lower at the end of December 2005. The lowest flow was [0.040 cms (1.4 cfs)] on November 26, 2005.

Flow (Wet And Dry Seasons of 2005-2006)

As occurred in the previous rainy season, flow was nearly always within the 75 th to 95 th percentile range during the wet season of 2005-2006 (Figure 5b) (United States Geological Survey 2006). Although rain fell in September and October 2005, high flow events most frequently occurred within the period of late winter through early spring of 2006 (Figure 5b). Flows during the wet season were almost always too high to be measured with a flow meter. 
During the dry season, flow values decreased but continued to be within the 75 th to 95th percentile range until mid October 2006. "Dry season flows" were maintained through November then increased in December 2006. The discharge percentile steadily decreased to being within the 50th percentile, and lower, in December 2006. The lowest flow in 2006 was 2.2 cfs on November 02, 2006.

\section{Status of Sandbar}

The sandbar formed at the San Gregorio Creek lagoon mouth during the dry season as a result of decreased freshwater inflows in combination with sand being built up by wave action (Table 1). In both 2005 and 2006, artificial breaching occurred after the sandbar first formed in August as well repeatedly each time the bar re-formed (Figure 6 and Table 1). Artificial breaching occurred through December until rainfall kept stream flows high enough to keep the lagoon mouth open. The longest period of time the lagoon stayed closed in the two years of sampling was for approximately 15 days.

In April 2008, during a dry year, the sandbar was partially closed at the mouth and was completely closed on June 22, 2008.

\section{Salinity}

Salinity in the San Gregorio Creek lagoon water column varied spatially and temporally. Salinity stratification at San Gregorio Creek lagoon was affected by the amount of freshwater inflow from San Gregorio Creek, the presence and elevation of the sandbar, the distance upstream of the ocean, the elevation of the lagoon channel bottom, 
the tidal height, and vertical mixing by wind. The patterns were similar in both 2005 and 2006 (Figures 7 -14).

During April and May of 2005 and 2006, stream flows were high enough to convert the entire water column in the estuary to freshwater. After stream flows decreased in June, saltwater penetrated at all stations except the uppermost stations (Stations \#11 and 12). Further stream flow reduction in July and August allowed saltwater intrusion at all stations. At this time, salinity profiles were similar throughout the lagoon, but with a thicker freshwater wedge at upstream stations. Sandbar development initiated the freshening of the lagoon; however, artificial breaching caused the draining of the less-dense freshwater layer from the lagoon into the ocean, increasing surface salinity at downstream stations and allowing saltwater tidal penetration to the uppermost stations. Lower summer stream flow, repeated artificial breaching, and lack of sustained sandbar closure during the dry season were accompanied by lack of conversion to freshwater and differentiation at all stations, except at Station \#12, which was completely fresh in both the beginning and end of the dry seasons due to adequate stream flows.

During April of the dry year (2008), as stream flows declined, saltwater penetrated into the estuary.

Salinity: June through December of 2005.--In June 2005, before the lagoon mouth closed, reduced freshwater inflow from San Gregorio Creek allowed saltwater intrusion from the ocean into San Gregorio Creek lagoon, stratifying the water column with the less dense freshwater layer on top of the denser saltwater layer (Figure 7a). The size of 
the freshwater wedge increased somewhat with distance upstream from the mouth. Only the farthest upstream station (Station \#12) was fully fresh. The bottom layer of Station \#9 was saline, but was at a slightly lower concentration (23.6-24.2 ppt) than those at all other downstream stations which were within $80 \%$ of the value of seawater.

By July 15, stratification was observed to occur at every station, and the halocline depth values (freshwater wedge) slightly increased (approximate range $0.25-0.5$ ) with distance upstream from the mouth (Figure 7b). Conditions were similar on July 29 (Figure 7C).

On August 03, the sandbar closed at the San Gregorio Creek estuary mouth for the first time of the year as a result of beach development by wave action and low freshwater inflows (USGS flow was approximately $3.2 \mathrm{cfs}$ ). The location of the mouth closure was approximately in the middle of the beach between the bluffs located to the north and south. Within less than $24 \mathrm{hrs,} \mathrm{the} \mathrm{sandbar} \mathrm{was} \mathrm{artificially} \mathrm{breached,} \mathrm{and} \mathrm{the}$ mouth was open on August 04. On that day, the water column was shallow throughout the lagoon, and the halocline depth and the salinity values were similar among stations (Figure 8a, Table 1).

On August 05, the sandbar had again re-formed, but was breached within the next 3 days. Although the mouth was open on August 12, temporary sandbar closure had affected the upper freshwater layer depth among station locations (Figure 8b). The freshwater wedge size increased with distance upstream from the mouth. The farthest upstream station (Station \#12) was still stratified but the lower layer at this location had substantially lower salinity (no greater than $10 \mathrm{ppt}$ ) than that at all other downstream 
stations. During late August through the beginning of September, the sandbar remained open and the salinity profiles were similar in their salinity per depth at all stations (Figure 8c). Again, the freshwater wedge size very slightly increased (by approximately $0.1 \mathrm{~m}$ ) with distance upstream from the mouth.

The sandbar re-formed on approximately September 23 but was breached by September 24 and the lagoon was shallower and remained stratified (Figure 9a). The sandbar re-formed on September 30 and remained until it was artificially breached on October 13. Data collected less than 24 hours after the artificial breach reflected the process of the breaching event: the less-dense freshwater layer drained from the lagoon into the ocean, increasing surface salinity at the downstream stations (Stations \#3 and 6) (Figure 9b). The sandbar re-formed later on October 14, after data were collected and then was again artificially breached on October 27 . The salinity profiles on October 29 were similar throughout the lagoon (Figure 9c). A low elevation sandbar formed by November 18 and the lagoon was observed to be open at high tides only. The low elevation sandbar allowed for slightly greater depth of the upper freshwater layer, but since it allowed for substantial tidal overwash, it provided no chance for complete destratification with the low freshwater inflows (Figure 10a). On December 02, stream flows had substantially increased completely destratifing the furthest upstream station (Station \#12) and producing a deeper freshwater wedge at Station \#9 (Figure 10b).

Salinity: February through May 2006.--During February to May sampling period of 2006, San Gregorio Creek flows were high enough to keep the San Gregorio Creek estuary mouth open, as well as fully convert the shallow water column to freshwater 
throughout the estuary (Figure 11a-c). At high tides, waves were pushing the freshwater inflow back upstream. Low salinity measurements $(<0.5 \mathrm{ppt})$ during this period demonstrated that there was very minimal, if any, penetration of ocean water during high tides within the estuary.

Saltwater penetration and salinity stratification began occurring in late May to early June at flows of approximately $20 \mathrm{cfs}$.

Salinity: June through December of 2006.--As occurred in 2005, reduced freshwater inflow in June from San Gregorio Creek allowed saltwater intrusion from the ocean into San Gregorio Creek lagoon, stratifying the water column with the less dense freshwater layer on top of the denser saline layer (Figure 12a). On June 16, the size of the freshwater wedge increased somewhat with distance upstream from the mouth, but only the farthest upstream station (Station \#12) was fully fresh. The bottom layer of Station \#9 was very saline (25.1 -26.5 ppt), but less saline than all other downstream stations (25.0 -29.4 ppt).

By July 14, all stations were stratified, and salinity profiles at all stations were similar (Figure 12b). By August 11 and 18, the freshwater wedge was deeper at upstream stations (halocline depth was $0.5-0.65 \mathrm{~m}$ at Station \#12) than at stations located in the middle (halocline depth was $0.25 \mathrm{~m}$ at Station \#9) and downstream (halocline depth was $0.150 .25 \mathrm{~m}$ at Stations \#3 and 6) reaches of the open lagoon (Figures 12c and 13a). This was due to declining stream flow and upstream penetration of saltwater behind a developing sandbar. 
On August 24, the sandbar closed at the mouth of the estuary for the first time in 2006. The mouth was adjacent to the bluff located at the north end of the beach near the public walkway from the parking lot. Due to the location of the mouth closure, filling of the lagoon with freshwater inflow (and tidal overwash) flooded public access to the beach. Soon after sandbar formation, someone substantially notched the sandbar and the lagoon was breached approximately five days later. Down-cutting caused by the breach created a low elevation sandbar for the remainder of the season, causing the sandbar to be intermittently open and closed during high and low tides.

After artificial breaching, the sandbar re-formed on September 08 and was artificially breached again, in less than 24 hours, at the north end of the beach. During water quality sampling on September 08, numerous dead threespine sticklebacks (Gasterosteus aculeatus) were observed in the dewatered areas of the beach. Also on September 08, substantial differences in salinity profiles and halocline depths were observed among stations (Figure 13b). The size of the freshwater wedge again increased with distance upstream from the mouth. The location farthest upstream in the lagoon (Station \#12) was fully converted to freshwater due to a shallower lagoon.

On September 15, the mouth was open and all stations were observed to have similarly low halocline depth (halocline depth ranged from $0.25 \mathrm{~m}$ at Station \#3 to 0.35 at Station \#12), and salinity profiles at all stations were similar (Figure 13c). The low elevation sandbar re-formed on September 20 and the freshwater layer increased in depth at all stations; salinity profiles were similar throughout the lagoon on October 5 (Figure $14 a)$. 
Throughout October and December, the low-elevation sandbar was intermittently open and closed due to tidal cycles and artificial breaching, and all stations were stratified (Figure 14a-c). Therefore, as in 2005, due to repeated artificial breaching, the sandbar was not present long enough nor was the amount of freshwater inflow adequate to substantially destratify the water column of the lagoon and convert it toward freshwater during the June through December sampling period.

Salinity: April 2008.--Unlike spring 2005 and 2006, freshwater inflow on April 18, 2008 was substantially lower allowing saltwater intrusion from the ocean into San Gregorio Creek lagoon, stratifying the water column with the less dense freshwater layer on top of the denser saline layer (Figure 15). The sandbar was partially closed and seawater was observed washing over the bar and into the lagoon.

\section{Temperature}

Temperature in the San Gregorio Creek lagoon water column varied spatially and temporally (Figures 16-24). The temperature in the water column was driven by salinity stratification and lack of mixing (termed "meromixis") between the fresh and saltwater layers. Temperature was also driven by the following factors acting upon this stratification: weather (wind, solar radiation, and air temperature); water depth; tidal height; distance from the mouth of the lagoon; presence of sandbar; and freshwater inflow from San Gregorio Creek.

During the spring of the wet years (2005 and 2006), stream flows were high enough to convert the entire water column in the estuary to freshwater and no 
temperature stratification was observed. Almost always during the dry season, salinitystratification and meromixis drove heating of the bottom saltwater layer (termed the "solar collector effect") at all stations. In addition, spatial differences in temperature were also observed to occur during this period. The water column of stations located closest to freshwater inflow (Stations \#11-12) were completely destratifed and fresh due to elevated stream flows (June) causing the temperature to be consistent and relatively low throughout the water column. After reduced freshwater inflow by July, and saltwater stratification at all stations, the upstream stations still had greater freshwater wedge sizes and therefore had less-elevated temperatures than those stations located in the middle reach (Stations \#4-9) of the lagoon. The bottom saltwater layers of Stations \#1-3, the stations located closest to the mouth, were usually mixed by the tide and were therefore often cooler than those stations located in the middle lagoon reach (Stations \#4-9). During occasional, very high tides, cooling by the tide was observed in the bottom saltwater layer in all stations upstream through Station \#9 with progressively less effect upstream. The highest temperatures were observed in stations located in the middle reach of the lagoon. Station \#5 had the highest temperatures that were observed during this two year study, with temperature in the bottom saltwater layer $28.5^{\circ} \mathrm{C}$ on July 08 and $29.6^{\circ} \mathrm{C}$ on August 12, 2005.

During the spring of the dry year (2008), low stream flows allowed persistent salinity-stratification, causing intense temperature stratification.

Temperature: June through December of 2005.--In June 2005, before the lagoon mouth closed, reduced freshwater inflow from San Gregorio Creek allowed saltwater 
intrusion from the ocean into San Gregorio Creek lagoon, stratifying the fresh and saltwater layers of the lagoon. Tidal mixing with the saltwater layer of the lagoon created a water column profile that had slightly reduced bottom water temperature $\left(13.6^{\circ} \mathrm{C}\right.$ at $1.65 \mathrm{~m}$ depth $)$ compared to the surface water temperature $\left(15.6^{\circ} \mathrm{C}\right.$ at Station \#3's surface) (Figure \#16a). Throughout the remainder of the lagoon, there was little surface to bottom temperature difference.

By July 15, salinity stratification occurred at every station and lack of mixing between the fresh and saltwater layers had caused the "solar collector" effect with warmer bottom temperature at every station, including Station \#12 (Figure 16b). Additionally, stations located closest to the mouth (Stations \#3 and 6) exhibited both the solar collector effect, as well as some tidal cooling effect at the very bottom the bottom layer.

On August 04, all stations exhibited the solar collector effect in their bottom water layer, but Stations \#3 and \#6 were also significantly cooled by the tide (Figure 17a). On August 12, the water column at upstream Station \#12 was substantially destratified: the bottom saline layer was relatively smaller in proportion to water column depth and the salinity of the bottom layer dropped to $10.2 \mathrm{ppt}$ (Figure $17 \mathrm{~b}$ and Figure $8 \mathrm{~b}$ ). Water temperature was similar throughout the profile (Figure 17b). The solar collector effect was observed at all other stations (Stations \#3, 6, and 9) where salinity concentrations ranged from 24 to $27.8 \mathrm{ppt}$. Also, on this date, very high temperatures $\left(27.6^{\circ} \mathrm{C}\right.$ at Station \#6 and $25.6^{\circ} \mathrm{C}$ at Station \#9) were measured in the lower saltwater layer of the middle reach of the lagoon, in a reach too shallow to be cooled at this time by tide water. The 
highest temperature $\left(29.6^{\circ} \mathrm{C}\right)$ observed in the 2005-06 sampling period was on this date in the lower saltwater layer of Station \#5.

On September 09, bottom saltwater layer of Stations \#3 and 6 were both substantially heated by solar collection in the top of the saltwater layer and substantially cooled by the tide (Figure 17c). Stations \#9 and 12 on these dates exhibited a strong solar collector effect with very little tidal cooling. On September 24, during a neap tide period (O’Neil Surf Shop 2004), all stations (\#3, 6, 9, and 12) were observed to exhibit the solar collector effect without any tidal cooling (Figure 18a).

On October 14, less than 24 hrs after an artificial breach, the entire lower and middle lagoon had been drained and refilled with cooler tidal water (Figure 18b). The furthest upstream station, Station \#12, was unaffected by the tide and exhibited the solar collector effect in its bottom layer. The sandbar remained closed for approximately 13 days when it was again either naturally or artificially breached.

On October 29, all stations were again salinity-stratified and exhibited the solar collector effect (Figure 18c). During this period, bottom water temperatures were lowest at Station \#3 with tidal cooling. In November, all stations had relatively warm water in the bottom saltwater layer (Figure 19a). In December, surface temperatures were similar to those in November but temperatures in the bottom layer, although warmer than the surface, had cooled (Figure 19b). Salinity and temperature stratification persisted at most stations until runoff from rainfall in January 2006 produced flows high enough to keep San Gregorio Creek lagoon mouth open and fully converted the water column to freshwater. 
Temperature: February through May 2006.--During the sampling period of February through May 2006, high stream flow kept the San Gregorio Creek lagoon mouth open and fully converted the water column to freshwater (Figure 11a-c). The temperature of the destratified fresh water column was relatively consistent (within $0.5^{\circ} \mathrm{C}$ ) from top to bottom (Figure $20 \mathrm{a}-\mathrm{c}$ ).

Temperature: June through December of 2006.--In June 2006, before the lagoon mouth closed, reduced freshwater inflow from San Gregorio Creek allowed saltwater intrusion from the ocean into San Gregorio Creek lagoon, stratifying the fresh and saltwater layers of the lagoon. On June 16, salinity stratification drove meromixis between the fresh and saltwater layers, causing the solar collector effect to occur in the middle reach of the lagoon (at Stations \#6 and 9), increasing the temperatures in the bottom water layer (Figure 21a). The solar collector effect was not observed at Station $\# 3$, the station closest to the mouth, due tidal mixing with the saltwater layer that reduced the bottom water temperature. Additionally, the solar collector effect was not observed at Station \#12, the station located furthest upstream from the mouth. At Station \#12, the water column was completely destratified and fresh, allowing for a consistent temperature throughout the water column.

By July 14 , salinity stratification was observed at all stations, and the solar collector effect was observed in the lower saltwater layers of Station \#9 and, for the first time of the year, at saline-stratified Station \#12 (Figure 21b). Stations located closest to the mouth (Stations \#3-6) exhibited a cooling effect by the tide at the very bottom the water column. On August 11 during one of the highest tide events of the summer [tidal 
elevation of $1.9 \mathrm{~m}$ (6.3 ft) on August 10 (O’Neil Surf Shop 2005)], both the solar collector effect as well as a cooling effect by the tide were observed at the downstream and middle reaches of the lagoon (Stations \#3, 6, and 9) (Figure 22c). The furthest upstream station, Station \#12, was unaffected by cooling tide and exhibited the solar collector effect in its bottom saltwater layer.

On August 18, temperatures at the top of the saltwater layer at Station \#3 reached the highest level recorded $\left(25.7^{\circ} \mathrm{C}\right)$ among all stations for the year, but the bottom was cooled by tidal mixing (Figure 22a). All other stations on this date were affected by the solar collector effect but lacked tidal cooling.

On August 24, the sandbar closed for the first time in 2006. Soon after sandbar closure, someone substantially notched the sandbar and the lagoon breached approximately five days later. This resulted in the sandbar's being intermittently open and closed during high and low tides for the remainder of the season.

The sandbar reformed on September 04 and was artificially breached at the north end of the beach within 24 hours. On September 08 during a period of one of the highest tide events of the summer [tidal elevation of $1.7 \mathrm{~m}(5.7 \mathrm{ft})$ on September 08 (O'Neil Surf Shop 2005)], substantial differences in tidal cooling occurred at Stations \#3 and 6 (Figure 22b). Station \#9 still showed the solar collector effect because its water column was relatively deep and located further upstream from the mouth and tidal influence. The water column at Station \#12, the station located furthest upstream, was completely destratified and fresh, allowing for a consistent temperature throughout the water column. On September 15, bottom water temperatures were again lowest at the downstream reach 
(Station \#3) and increased among stations with distance upstream of the mouth to Station \#12 (Figure 22c).

On October 05, after a period of sandbar closure, all stations were deeper and had similar halocline depth and temperature values throughout their profiles (Figure 22a). The two deepest stations (Stations \#3 and 9) also showed recent cooling by the tide. On November 02, after breaching, the shallower lagoon showed the solar collector effect at all stations (Figure 23b).

On November 30, when the air temperature had substantially decreased, temperatures of the entire water column decreased (range on November 30 dropped to 4.5 $-16.4^{\circ} \mathrm{C}$ ) at all stations despite the persistence of salinity stratification and meromixis that continued to trap heat in the bottom saltwater layer (Figure 23c). Salinity and temperature stratification persisted at most stations until runoff from rainfall in 2007 produced flows high enough to keep San Gregorio Creek lagoon mouth open and fully converted the water column to freshwater.

Temperature: April 2008.--Unlike spring 2005 and 2006, freshwater inflow on April 18, 2008, was substantially lower allowing saltwater intrusion into the lagoon and salinity stratification. At Station \#3, salinity stratification drove meromixis, causing the both heating (solar collector effect) of the upper part of the saltwater layer and the cooling of the bottom of the water column by the tide (Figure 24). 


\section{Secchi Depth And Vegetation}

In the period of June through December of both 2005 and 2006, secchi depth was most often greater than the depth of the water column allowing for sunlight to penetrate to the bottom (Figure 25a-b). This allowed for photosynthesis throughout the water

column. In December of this period, secchi depth was at its lowest value due to increased stream flow elevating turbidity levels as well as due to the presence of phytoplankton. Algae was present throughout the June through December sampling period at every station, and was most abundant during the period of June through August. Secchi depth measurements and greenish water color showed phytoplankton to be a major source for primary production throughout the water column and throughout the dry season, especially prior to full establishment of Potamogeton sp. in August when turbidity declined. Potamogeton sp. was most abundant at Stations \#4 through 8, and was observed to be most abundant during August through October.

\section{Dissolved Oxygen}

Dissolved oxygen concentrations in the San Gregorio lagoon water column varied spatially and temporally. The dissolved oxygen concentration in the water column was driven by the stratification of the less-dense freshwater layer on top of the denser salt water layer, as well by the following factors acting upon this stratification: weather, decomposition of organic matter, time of day as it affects respiration and photosynthesis, water depth, tidal height, distance from the mouth of the lagoon, presence of sandbar, mixing by the wind, and freshwater inflow from San Gregorio Creek. 
Almost always during the summer and fall, salinity-stratification and meromixis was accompanied by oxygen stratification in the water column at all stations. At all stations, dissolved oxygen concentrations fluctuated diurnally, especially in the bottom saltwater layer, due to photosynthesis and respiration by plants. Diurnal dissolved oxygen fluctuations were especially pronounced due to algal growth, particularly Enteromorpha sp., as well as due to seasonal growth of rooted vascular vegetation, Potamogeton sp. In addition, periods of persistent fog reduced diurnal fluctuation and produced lower dissolved oxygen concentrations.

In addition to these spatial patterns, spatial differences in dissolved oxygen concentrations were also observed to occur during the summer and fall. The water column of stations located closest to freshwater inflow (Stations \#11-12) were completely destratifed and fresh due to higher stream flows during June; the dissolved oxygen concentrations were relatively consistent and high throughout the water column. Once reduced freshwater inflow allowed saltwater stratification to occur for the remainder of the dry season at all stations, photosynthesis often caused supersaturation of dissolved oxygen at the top of the saltwater lens and decomposition, combined with respiration, often caused hypoxic or anoxic conditions at the bottom of the water column. During summer's high tide events, stations located closest to the mouth (Stations \#1-3) often had higher bottom dissolved oxygen than those stations located further upstream due to tidal mixing with the bottom saltwater layer. In addition, shallower stations (middle lagoon reach Stations \#4-6) and upstream stations with proportionally greater freshwater wedges (and shallower saltwater layers) had higher bottom dissolved oxygen than deeper stations. 
Deeper stations had greater accumulation of decomposing organic matter and therefore increased respiration. They also had less sunlight penetration to the bottom of the water column, thus limiting the potential of increasing dissolved oxygen concentrations by photosynthesis.

Repeated artificial breaching kept the lagoon salinity stratified, and respiration and decomposition within the stratified lagoon reduced the concentrations of dissolved oxygen in the bottom saltwater layer. Breaching events also allowed entry of marine algae (Ulva sp.) and bull kelp (Pelagophycus giganteus) into the lagoon during the high tide conditions. Kelp was often observed as far upstream as the middle reach of the lagoon (Stations \#6 and 7). The algae and kelp produced a decaying organic layer on the lagoon bottom. Additionally, I detected the odor of hydrogen sulfide and observed black material characteristic of hydrogen sulfides in the sediment at locations throughout the lagoon during the summer and fall of 2005 and 2006.

During the spring of the dry year (2008), low stream flows allowed salinity stratification, causing dissolved oxygen stratification.

Based upon salmonid reponses (Barnhart 1986), dissolved oxygen concentrations of $7 \mathrm{mg} / \mathrm{L}$ or above are referred to as "good" or "high"; concentrations of 4.1-7 mg/L are referred to as "fair"; concentrations of $0.5-4 \mathrm{mg} / \mathrm{L}$ are referred to as "hypoxic". Values that were less than $0.5 \mathrm{mg} / \mathrm{L}$ are defined as "anoxic".

Dissolved oxygen: June through December of 2005.--On June 17, tidal mixing with the salinity-stratified lagoon cooled and oxygenated the lower saltwater layer at Stations \#3, 6, and 9 to generally high concentrations that were relatively consistent from 
top to bottom (Figure 26a). Station \#12, the station located furthest upstream from the mouth, was still completely fresh throughout the water column allowing for consistently high dissolved oxygen throughout the water column.

By July 15, salinity stratification occurred at all stations, including at Station \#12, and oxygen stratification in the water column was observed at every station (Figure 26b). Dissolved oxygen concentrations were supersaturated at the top of the saltwater lens and were hypoxic to anoxic at the bottom of the water column at Station \#6. Concentrations were fair at the bottom of Station \#9. On July 29, supersaturation of dissolved oxygen remained at the top of the saltwater lens at Stations \#3 and 6. However, decomposition combined with respiration reduced dissolved oxygen concentrations to a hypoxic condition at the bottom of the water column at all stations.

On August 03, the sandbar closed at the San Gregorio Creek estuary mouth for the first time of the year. Within 24 hours, the sandbar was artificially breached. On August 04, dissolved oxygen concentrations were generally high, except at Station \#6, but were lower in the bottom water layer due to decomposition combined with respiration (Figure 27a). On August 12, dissolved oxygen was high at Station \#6, which was sampled at a shallower location, and supersaturated at Stations \#3 and 9 (Figure 27b). Dissolved oxygen concentrations were hypoxic at the bottom of the water column at Station \#12.

On September 09, after a period of prolonged fog, decomposition combined with respiration reduced dissolved oxygen concentrations to hypoxic and anoxic conditions at the bottom of the water column at Station $\# 9$ and were at the borderline of fair to hypoxic 
conditions at Stations \#6 and 12 (Figure 27c). The lower saline layer at Station \#3 was being mixed with the tide and was the only station that had good dissolved oxygen throughout. On September 24, again after a prolonged period of fog, most of the water column of all four stations was in both the fair and hypoxic dissolved oxygen ranges due to decomposition combined with respiration in the lower saline layer (Figure 28a). Only the wind-mixed, upper freshwater layer of the water column at all four stations had dissolved oxygen in good condition.

On October 14, less than 24 hrs after an artificial breach, the less dense freshwater layer had drained from the lagoon into the ocean and the entire water column of Station \#3 was very saline. At that time, the dissolved oxygen at Station \#3 increased to high levels and became consistent throughout the water column (Figure 28b). Stations located further upstream from the mouth were still salinity stratified and exhibited more variation in dissolved oxygen concentrations. The saline bottom layer at Station \#6 had higher dissolved oxygen concentrations than in its upper freshwater layer due to substantial tidal mixing in the lower layer. Dissolved oxygen concentrations for the entire water column at Station \#9 were within the fair condition range. At Station \#12, the lower layer mixed the least after the breach; the water column was still salinity stratified and the bottom saline layer was still hypoxic compared to the upper freshwater layer which was in good condition.

On October 29, the upper freshwater layer was in good condition throughout the lagoon. However, most of the water column at all stations was in the fair to hypoxic dissolved oxygen range, and the lowest concentrations were observed to be anoxic at the 
bottom of the water column at Stations \#9 and 12 (Figure 28c). Low dissolved oxygen concentrations in the lower saltwater layer were due to the presence of thick fog reducing photosynthesis and also due to decomposition and respiration. On November 18, sunny and warm weather conditions increased photosynthesis, causing supersaturation at the top of the saltwater lens. But, the bottom water remained hypoxic except at tidally-mixed Station \#3 (Figure 29a). On December 02, recent rain increased stream flow and fullyconverted the water column at Station \#12 to freshwater. This conversion allowed adequate mixing throughout the water column and increased the dissolved oxygen concentrations to high levels throughout (Figure 29b). The stations located downstream continued to be salinity stratified and their lower saline layers were determined to be in fair and hypoxic conditions.

Salinity and oxygen stratification persisted until runoff from rainfall in winter 2006 produced flows high enough to keep the San Gregorio Creek lagoon mouth open and fully converted the water column to freshwater.

Dissolved oxygen: February through May 2006.--During the sampling period of February through May 2006, rain produced flows high enough to keep the San Gregorio Creek lagoon mouth open and fully converted to freshwater. Because the water column was destratified and completely fresh, mixing occurred throughout the water column, allowing for consistently high dissolved oxygen (Figure 30a-c).

Dissolved oxygen: June through December of 2006.--In June 2006, before the lagoon mouth closed, declining freshwater inflow from San Gregorio Creek allowed saltwater intrusion from the ocean into San Gregorio Creek lagoon, stratifying the fresh 
and saltwater layers of the lagoon. On June 16, tidal mixing with the lagoon cooled and oxygenated the lower saltwater layer at Stations \#3, 6, and 9, and the dissolved oxygen concentration throughout the water column at these stations was generally high and relatively consistent from top to bottom (Figure 31a). Station \#12 was still fresh throughout the water column allowing for consistently high dissolved oxygen.

By July 14, salinity stratification was present at all stations, including at Station $\# 12$, and some oxygen stratification in the water column was present at every station (Figure 31b). Supersaturation of dissolved oxygen was observed at the top of the saltwater lens at the downstream and middle reaches (Stations\#3, 6 and 9) of the lagoon. Decomposition combined with respiration slightly reduced dissolved oxygen concentrations at the bottom of the water column at all locations within the lagoon. Despite variations within the water column, all dissolved oxygen concentrations were in good condition.

On August 11, with the sandbar developing and reduced tidal mixing, decomposition and respiration combined to slightly reduce dissolved oxygen concentrations at the bottom of the water column at all stations (Figure 32a). The top of the water column at all stations had good dissolved oxygen concentrations, and the bottom of the water columns were fair to hypoxic. The deeper downstream stations had lower dissolved oxygen concentrations than the shallower upstream stations. Dissolved oxygen concentrations increased in the afternoon on this date (Figure 32a-b), as on other dates. Stations \#3 and 9 were the deepest and also had the lowest dissolved oxygen concentrations on the bottom. On August 18, supersaturation of dissolved oxygen was 
observed at the top of the saltwater lens at all stations, with substantially reduced dissolved oxygen levels below the halocline at all stations (Figure 33a). Despite these fluctuations, all stations, except for Station \#3, had high dissolved oxygen concentrations. Stations \#3 had high dissolved oxygen concentrations above the halocline; however, below the halocline, levels were fair or hypoxic.

On August 24, the sandbar closed at the mouth of the estuary for the first time in 2006, but the bar was breached approximately five days later. The lagoon was intermittently open and closed during high and low tides for the remainder of the season.

On September 08, dissolved oxygen concentrations were substantially greater within the upper freshwater layer at Station \#12 than at the upper layer at all other stations (Figure 33b). On this day, dissolved oxygen concentrations in the entire water column at all stations were generally good despite the reduction of dissolved oxygen concentrations in the lower saline layer by decomposition and respiration. On September 15, supersaturation of dissolved oxygen was observed at the top of the saltwater lens at all stations, with reduced dissolved oxygen at the bottom of the water column at all stations (Figure 33c). Despite the lower dissolved oxygen concentrations in the bottom of the lower saline layer, the dissolved oxygen concentrations in the entire water column were generally good with the slight exception of the deepest station, Station \#3, which had fair condition at the very bottom of the water column.

On October 05, with a deep, generally closed lagoon, decomposition and respiration combined to substantially reduce dissolved oxygen concentrations in the lower saline layer at all stations (Figure 34a). The deepest stations, Stations \#3 and 9, 
had the lowest dissolved oxygen concentrations on the bottom of the water column, and levels were anoxic for approximately half of the depth of their water columns. Shallower stations, Stations \#12 and 9, were generally fair and hypoxic only at the bottom.

On November 02, dissolved oxygen was low in the lower saline layer at all stations (Figure 34b). Stations located furthest upstream from the mouth, Stations \#9 and 12 , had the lowest dissolved oxygen concentrations in their lower saline layer, and levels were hypoxic. Despite lowered dissolved oxygen concentrations in the lower saline layer, concentrations within the entire water columns at the other two stations, Stations \#3 and 6, were in fair and good condition because of tidal mixing. On November 30, approximately half of the volume of the water column at Stations \#3, 9, and 12 had dissolved oxygen concentrations that were in good condition and the bottom half of the volume was in fair and hypoxic condition (Figure 34c). The dissolved oxygen concentration at shallow Station \#6 was good for most of the water column, but fair at the bottom.

Salinity and oxygen stratification persisted until higher runoff in 2007 produced flows high enough to keep the San Gregorio Creek lagoon mouth open and fully converted the water column to freshwater.

Dissolved Oxygen: April 2008.--Unlike spring 2005 and 2006, reduced freshwater inflow on April 18, 2008 allowed tidal mixing with the lagoon at Station \#3 cooling and oxygenated the lower saltwater layer (Figure 35). The dissolved oxygen concentration throughout the water column at Station \#3 was consistently high from top to bottom. 


\section{Lagoon / Estuary Utilization by Fishes}

Eleven species of fish were captured in San Gregorio Creek lagoon during the 2005-2006 sampling. Due to the repeated artificial breaching during the two years of sampling, the lagoon was open intermittently throughout the dry season and accessible by marine species. The euryhaline species, in order of the highest to lowest capture rate, were: steelhead; threespine stickleback; starry flounder (Platichthys stellatus); staghorn sculpin (Leptocottus armatus); prickly sculpin (Cottus asper); tidewater goby (Eucyclobius newberryi); top smelt (Atherinops affinis); barred surf perch (Amphistichus argenteus); striped bass (Roccus saxatilis); coho salmon (Oncorhynchus kisutch); and shiner surf perch (Cymatogaster aggregata).

Seine mesh size biased species catch and length of fish collected. Small gobies were often observed in abundance but rarely collected.

Coho salmon were not captured in the lagoon during the summer / fall rearing season in either 2005 or 2006 . They were only captured as outmigrating smolts in April and May 2006.

Summer / Fall Steelhead Rearing in 2005

The steelhead population estimates slightly decreased during the summer and fall of 2005. From July 01 to October 27 the population estimate decreased $15 \%$ from 2,365 \pm 598 to $2,005 \pm 715$ (Figure 36 ). The steelhead captured throughout this period consisted of three age classes: $0+; 1+$; and $2+$. On July 01 , most aged steelhead $(n=57)$ were age $1+(75.4 \%)$, followed by $0+(22.8 \%)$ and $2+(1.8 \%)$ (Figure $37 \mathrm{a})$. In samples 
from October $27(\mathrm{n}=71)$, the relative abundance of $1+(52.1 \%)$ substantially decreased, as $0+(43.7 \%)$ increased, and $2+(4.2 \%)$ remained approximately the same (Figure 37b).

The steelhead captured in the lagoon increased in standard length from a range of 50 to $175 \mathrm{~mm}$ on July 01 to a range of 110 to $185 \mathrm{~mm}$ on October 27 (Figure 37). Also during this period, the mean standard length per age class substantially increased, but length frequencies of age groups fully overlapped, forming a unimodal distribution.

The mean standard lengths of all three age classes increased most during the interval of July 01 to August 15 and of September 20 to October 27 (Figure 38). No substantial change was observed in the mean standard lengths for all three age classes between August 15 and September 20 when the lagoon was repeatedly breached, salinitystratified, and very warm.

Steelhead captured in the lagoon on October 27 were substantially larger than those captured on November 15 in the two stream reaches, one on San Gregorio Creek ( $\mathrm{p}$-value of age $0+=7.19 \times 10^{-27}$ where $\mathrm{p}<0.01$ ) and one on Alpine Creek ( $\mathrm{p}$-values of age $0+=3.61 \times 10^{-30}$ and of age $1+=6.43 \times 10^{-7}$ ). Of the two stream reaches, steelhead collected in San Gregorio Creek (size range 60-150 mm SL) were substantially larger (pvalue of age $\left.0+=7.13 \times 10^{-9}\right)$ than those captured at Alpine Creek (40-130mm SL) (Figure 39). The p-values of age 1+ was not determined at San Gregorio Creek due to small sample size $(n=3)$.

Steelhead captured at San Gregorio Creek on November 15, 2005, two months before the winter rains, included two age classes $(0+$ and $1+)$ and those captured at Alpine Creek consisted of four age classes $(0+, 1+, 2+$, and 3+) (Figure 39). At San 
Gregorio Creek, most steelhead were age $0+(89.7 \%)$ and the remainder were $1+(10.3 \%)$ (Figure 39a). At Alpine Creek, most steelhead were age 0+ (65.6\%) and age 1+ (25.0\%).

\section{Winter / Spring Steelhead Rearing and Smolt Out-Migration in 2006}

The steelhead population estimates were the lowest for the year 2006 during the winter (74 \pm 8 on February 16) and early spring (36 \pm 12 on May 15), and then substantially increased in the late spring $(1,362 \pm 73$ on June 15) (Figure 39). It appeared that most smolts migrated through the lagoon without stopping since no recaptures occurred.

From the period of February 16 to April 27 (and through May 19), the mean standard lengths of all three age classes $(1+, 2+$ and $3+)$ decreased as smolts outmigrated to the ocean leaving smaller fish behind (Figure 40). The range of standard lengths of steelhead juveniles captured in the lagoon was similar on February 16 (95 to $200 \mathrm{~mm} \mathrm{SL)}$ and March 16 (110 to $215 \mathrm{~mm} \mathrm{SL}$ ) then broadened in range (65 to $215 \mathrm{~mm}$ SL plus one adult, $275 \mathrm{~mm} \mathrm{SL}$ ) by April 27 when smolts and yearling juveniles entered the lagoon from the stream and a jack adult entered from the ocean (Figure 40 and 41a). The steelhead captured during this period consisted of three age classes: $1+; 2+$; and 3+ (Figures 40-41a). No 0+ were captured during this time. Age $2+$ fish dominated in both February 16 (63.1\%) and March 16 (58.8\%). By April 27, two age classes, age 1+ $(49.3 \%)$ and $2+(43.5 \%)$, were equally common when smaller yearlings were beginning to enter the lagoon from the stream. 
By May 19, age 0+ steelhead were large enough to be first captured in the lagoon, and the larger sized smolts were observed to have outmigrated from the lagoon to the ocean (Figure 41b). By June 15, the steelhead population estimate had substantially increased as did the relative abundance of age $0+(17.7 \%)$, as juvenile steelhead continued to enter the lagoon from the stream (Figures 36, 42, and 43). Age 1+ (76.6\%) still were most abundant at this time. From the period of May 16, 2006 to June 16, 2006, the mean standard lengths of the three age classes $(0+, 1+$, and $2+)$ increased due to rapid growth within the lagoon habitat.

Summer / Fall Steelhead Rearing in 2006

The population estimate was highest for the year 2006 during the seining event which occurred on July 19. From July 19 to November 11, the population estimate decreased $51 \%$ from $2,802 \pm 354$ to $1,373 \pm 610$ (Figure 36).

The steelhead captured throughout this period consisted of three age classes: 0+; $1+$; and 2+ (Figure 44). On July 19, 2006, most steelhead were age $1+(66.0 \%)$, followed by $0+(26.8 \%)$ and $2+(7.2 \%)$. By November 03,2006 , the relative abundance of age $1+$ $(55.1 \%)$ decreased, as age $0+(41.0 \%)$ increased. Age $2+(3.8 \%)$ remained similarly scarce.

During the period of early summer to mid fall of 2006, steelhead captured in the lagoon increased in standard length from a range of 60 to $185 \mathrm{~mm}$ (on July 19, 2006) to a range of 110 to $200 \mathrm{~mm}$ (on November 03, 2006) (Figure 44). Also during this period, 
the mean standard lengths of all three age classes substantially increased by November 11, 2006.

\section{Spring Steelhead Rearing and Smolt Out-Migration in 2008}

On April 18, 2008, most captured steelhead were smolts age $2+(80.0 \%, \mathrm{n}=52)$, followed by age $1+(13.8 \%, n=9)$, then by $3+(6.2 \%, n=4)$ (Figure 45$)$. This population was proportionally older than it was two years earlier (on April 28, 2006) when the population was dominated, nearly equally, by two age classes, age $1+(48.6 \%)$ and $2+$ (42.9\%) (Figure 41a). Additionally, the April 2008 population consisted of larger fish (mostly within the 115-215 mm SL range) than did the April 2006 population (mostly within the 65-215 mm SL range). Proportionally, fewer juveniles in April 2008 had migrated into the lagoon and fewer smolts had outmigrated from the lagoon than had been observed in April two years earlier. Fish in April were quite "plump" in the presence of a plankton bloom and common Neomysis shrimp as potential food.

Also on April 18, 2008, substantial overlapping of age classes was observed in the length frequency distribution. Spring growth increments on scales were substantial but highly variable, apparently reflecting differences in duration of feeding in the productive lagoon. The partially impounded salinity-stratified lagoon in April 2008 was therefore more productive than it was in April 2006 when it was shallow, destratified and completely fresh. 
Spatial Patterns of Steelhead Lagoon Use in 2005

From the period of July 01 to September 20, 2005, 137 steelhead were left pelvic fin clipped (LPFC) in the upstream "Middle Lagoon Station (I)" (located in the vicinity of water quality Stations \# 6 and 7) and 1,176 steelhead were right pelvic fin clipped (RPFC) in the downstream "Lower Lagoon Station" (in the vicinity of water quality Stations \#2 and 3). Rapid regeneration of fins made it difficult to determine recapture rates after more than one month had passed.

Limited recapture data showed a gradual overall movement of steelhead in a downstream direction to the best habitat at the Lower Lagoon Station. From the period of July 01 to September 20, 2005, fish marked in the Middle Lagoon Station were only recaptured (at rates of $0.73 \%$ ) during subsequent sampling events in the Lower Lagoon Station. Fish marked at the Lower Lagoon Station were recaptured during subsequent sampling dates at both the same Lower Lagoon Station (at rate of 2.98\%) and also at the Middle Lagoon Station (at a rate of $0.26 \%$ ).

During the period of July 01 through October 27, 2005, the total steelhead catch (two seine hauls per station) was always substantially greater in the downstream Lower Lagoon Station than in the upstream Middle Lagoon Stations (I) and (II). These results indicate that steelhead were most abundant in the Lower Lagoon Station (Figure 46) (Figure 3).

Additionally, more variability in total catch was observed in Lower Lagoon Station than in the upstream Middle Lagoon Stations (I) and (II) due to greater variability in seining efficiency at the Lower Lagoon Station. Seining efficiency differences 
between the Lower and Middle Lagoon Stations and between dates within Stations was based on differences of the depth of impounded water. When the lagoon was fully open and the surface water elevation was low, total catch at the Lower Lagoon Station was relatively high. Conversely, when the lagoon was closed, or nearly closed, and the surface water elevation was relatively high, total catch at the Lower Lagoon Station was lower. When the lagoon closed, or was nearly closed, after a period of being fully open, the total catch increased at Middle Lagoon Station I and stayed relatively constant at Middle Lagoon Station (II).

The largest difference between the mean standard length of steelhead captured at the Lower Lagoon Station versus the Middle Lagoon Station during the period of July 01 through October 27, 2005 occurred on July 01 when there was still an overall movement of smaller juvenile steelhead in a downstream direction to the best habitat at the Lower Lagoon Station (Figure 47). For the remainder of the sampling, the mean length of steelhead and the age class structure at both Stations were very similar by October 27 (Figures 47, 48, and 49).

Rearing Strategies of Successful Adult Steelhead Captured in April 2008

On April 28, 2008, 23 adult steelhead were captured. All but one were in postspawning condition. No scales were taken from the single upmigrant. Also, 21 of these adults were females.

Scale analyses showed that 12-14 (55-64\%) of this small sample of adult fish reared (had large annual growth increments) as age $0+$ or $1+$ in the lagoon (Table 2). 
Scale analyses also showed that 16-17 (73-77\%) of these adults spent only one year in the ocean prior to spawning for the first time.

Five freshwater rearing strategies were determined by scale analyses of the adult steelhead: $1 \mathrm{yr}$ in lagoon only $(\mathrm{n}=6-7) ; 1 \mathrm{yr}$ in stream $+1 \mathrm{yr}$ lagoon $(\mathrm{n}=6-7) ; 1 \mathrm{yr}$ in stream only $(n=2) ; 2$ yrs in stream $(n=5-7) ; 3$ yrs in stream $(n=1)$. Steelhead that reared in the lagoon entered at age $0+$ or $1+$ at a relatively small size (recognized as slow growth and small size prior to a sharp increase in circuli spacing upon entering the lagoon).

Of the 22 adults from which scales were analyzed, back-calculation of the mean standard length at ocean entry was $186 \mathrm{~mm} \pm 26.4$. This value was greater than the mean lengths determined from juveniles sampled in the fall in the lagoon in years 2005 (161 $\mathrm{mm} \pm 11.3$ to $170 \mathrm{~mm} \pm 13.2$ for age classes $0+$ to $2+)$ and $2006(141 \mathrm{~mm} \pm 13.4$ to $173 \pm$ 2.90 for age classes $0+$ to $2+)$, as well as in the two stream reaches $(92 \pm 20$ to $123 \pm 16.1$ for age 1+ fish) in 2005 (Table 3). Values measured of juveniles in the field, however, do not account for the additional spring growth prior to their ocean entry. 


\section{Discussion}

To better understand the temporal and spatial relationships of water quality parameters as well as steelhead habitat use and growth in San Gregorio Creek estuary / lagoon, I studied water quality and steelhead at San Gregorio Creek estuary / lagoon over two wet years during which this lagoon was repeatedly artificially breached, thereby allowing little ability to observe freshwater conversion. I found that in this salinitystratified condition, dissolved oxygen concentrations were often substantially depressed and temperatures were often substantially elevated in the lower saltwater layer of the lagoon. My data showed a positive relationship between steelhead abundance in the lagoon and water column depth, and I believe, based on known water quality tolerances of steelhead, it is likely that these fish utilized the middle to upper water column when water quality at the bottom of the water column was poor. I found that despite poor water

quality conditions in the lagoon, steelhead that reared in the estuary / lagoon were still substantially larger than those sampled in the two stream reaches, one reach in the lower watershed on San Gregorio Creek and one in the upper watershed on Alpine Creek.

\section{Water Chemistry}

During the summer and fall of 2005 and 2006, San Gregorio Creek lagoon was repeatedly artificially breached, allowing little opportunity for freshwater conversion. Salinity stratification and meromixis drove heating of the bottom saltwater layer to occur at all stations, and bottom water temperatures reached levels that challenged steelhead thermal tolerances in July and August $\left(28.5^{\circ} \mathrm{C}\right.$ to $\left.29.5^{\circ} \mathrm{C}\right)$. The bottom saltwater layers of 
stations located closest to the mouth were mixed by the tide and were therefore often cooler. Upstream stations that had greater freshwater wedge sizes generally had lesselevated temperatures than those stations located in the middle reach. Similar spatial patterns for temperature were observed during the time of sandbar formation by Smith (1990) and Robinson (1993) in San Mateo County lagoons and by Cannata (1998) in two Mendocino County lagoons. All three researchers observed both the solar collector effect driven by salinity stratification and meromixis, as well as the cooling effect in the lower saltwater layer located closest to the mouth when the lagoons were open.

I found that salinity stratification and meromixis additionally drove oxygenstratification in the water column at all stations; dissolved oxygen on the bottom was frequently hypoxic. During the dry season's high tide events, stations located closest to the mouth often had greater dissolved oxygen concentrations in the lower saltwater due to tidal mixing as did the most upstream stations which had proportionally greater freshwater wedges. Repeated artificial breaching throughout the dry season not only salinity stratified the lagoon, it allowed entry of bull kelp and other algal detritus into the lagoon during high tide events, which decomposed in the lagoon, further driving down dissolved oxygen concentrations at the bottom of the water column. Similar observations were reported by Robinson (1993) after an artificial breach at Pescadero Creek lagoon and by Smith (1990) at Waddell Creek lagoon.

In their work at San Mateo and Santa Cruz County estuaries / lagoons, Smith (1990) and Sloan (2006) reported salinity to be the main component driving temperature and dissolved oxygen levels in the water column, and Cannata (1998) reported that 
salinity drove water quality conditions at the Navarro River estuary / lagoon in Mendocino County.

\section{Fish Community}

During the 2005-2006 sampling period, eleven species of fish were captured in San Gregorio Creek estuary / lagoon. Due to the repeated artificial breaching, the lagoon was open intermittently each summer and accessible to marine species, including the predatory, non-native striped bass, which are known to feed on steelhead. However, striped bass were relatively small $(75-174 \mathrm{~mm}, \mathrm{n}=25)$ and were collected only during three sampling events (May June and July) in 2006.

During estuary / lagoon sampling, coho salmon smolts were captured only during spring 2006, during the time of their outmigration to the ocean. If feeding and saltwater transition habitat is available in the spring, this could be important for coho salmon success in the watershed by substantially increasing smolt size and ocean survival. However, coho salmon did not utilize the lagoon for rearing in 2005 although they were present upstream. Cannata (1998) in his study of the Navarro River estuary / lagoon, reported no rearing by coho salmon despite their presence in the watershed. Smith (1990) reported the absence of coho salmon rearing in San Mateo and Santa Cruz County lagoons as did Hayes et al. (2008) in the Scott Creek estuary / lagoon, Santa Cruz County. Elevated temperatures in the estuary / lagoon during and after sandbar formation may be too high for coho salmon preferences (or tolerances), especially in repeatedly breached lagoons where meromixis persists. Coho salmon may be able to tolerate such 
temperatures if competition is lacking (Welsh et al. 2001), but steelhead competitors are always common competitors in the lagoons. Welsh et al. (2001), in his study on the Mattole River in Northern California, found that juvenile coho salmon were most abundant in reaches of $18^{\circ} \mathrm{C}$ or less but he also noted that other ecological factors such as competition play a role in influencing temperature preference. Bisson et al. (1988) reported that coho salmon productivity in Washington streams was high after the Mount Saint Helens eruption killed all fish, while only this species had been reintroduced into the stream. This high productivity occurred despite these streams' temperatures exceeding $24.5^{\circ} \mathrm{C}$ for more than 100 hours with a maximum of $29.5^{\circ} \mathrm{C}$. The effect of temperature is an important factor in coho salmon presence since at cooler temperatures coho salmon are able to outcompete steelhead (Hartman 1965; Harvey and Nakamoto 1996)

\section{Steelhead}

The steelhead captured in San Gregorio Creek lagoon during both years were substantially larger overall and for each age group than those captured in both stream reaches in October and November 2005. This indicates that the lagoon habitat provided much higher growth than that of the streams. Additionally, steelhead captured in San Gregorio Creek were substantially larger at each age and consisted of fewer age classes (ages $0+$ and 1+) than those captured at Alpine Creek (ages $0+, 1+, 2+$, and 3+), indicating that the reach sampled on San Gregorio Creek was more productive than that on Alpine Creek. 
Estimated steelhead populations were similar in the beginning of the summer of both $2005(2,365)$ and $2006(2,802)$. By late fall of both years, estimated populations declined; the 2005 population decreased $15 \%$ and the 2006 population declined $51 \%$. Intraspecific competition and / or loss to avian predators are possible explanations for the declines. Population declines do not appear to be due to fish leaving the lagoon because shallow riffles likely prevented upstream movement. They did not appear to be flushed to the ocean during breaching events because residual habitat depth was sufficient at San Gregorio lagoon. Smith (1990) also found that fish remained during breaching at San Gregorio in 1986, but has observed substantial fish loss to the ocean during breaching of shallower, simpler lagoons, such as at Scott Creek. Because population estimates were determined within the same day as marking at every sampling event except during the fall of 2005, it is possible that during the 2006 fall sampling, the fish did not randomly mix between marking in the morning and recapture effort in the afternoon, which would under-estimate the population.

In 2005, the length frequency distribution became more unimodal by late fall due to rapid steelhead growth especially by smaller fish. The relative abundance of age $0+$ also increased either as more fish entered the lagoon over summer or because many age 0+ were too small to capture on July 01 . Thus, the time spent rearing in the lagoon was more important in size determination than was age. Smith (1990) found this same effect for steelhead captured in San Mateo and Santa Cruz County lagoons.

The range in the length frequency distribution of steelhead was wider by fall of 2006 compared to 2005, but the proportion of age $0+$ increased similar to that in 2005 . 
By fall of 2006, the median standard lengths of ages $1+$ and $2+$ increased to similar sizes as those of the same age classes at the end of the previous year. However, the median standard length of age $0+$ was substantially smaller than that at the end of 2005. Smaller sizes for age 0+ may have indicated later movement to the lagoon with less time for growth. However, the lower November population estimate indicates possible mortality and slow growth in the midsummer to fall.

Similar observations of length frequency distributions were observed by Smith (1990) in his study of San Mateo and Santa Cruz County estuaries / lagoons, and he reported that growth rates were directly related to water quality. Specifically, Smith (1990) reported that when water quality conditions in the estuaries / lagoons were poor (high temperatures and low dissolved oxygen concentrations), growth rates were likewise poor. Furthermore, he found the size frequency distribution remained bimodal because age $0+$ did not catch up in size to age $1+$. Conversely, when water quality conditions were good, he found that growth rates were high and the distribution was unimodal by the end of the summer / fall. Laboratory analysis of steelhead raised in captivity showed that given ample (and equal) amounts of food, smaller steelhead, which have lower absolute food demands, grew faster than larger steelhead (Wurtsbaug and Davis 1977a; Connolly and Peterson 2003), thus providing an explanation to the narrowing of the length frequency distribution.

Despite smaller sizes of age $0+$ and greater reduction in the population estimate in summer / fall 2006 compared to 2005, water quality conditions in San Gregorio Creek lagoon during both years appeared to be similar. Both were wet years and the sandbar 
was repeatedly artificially breached during both years. Furthermore, the water column was salinity-stratified during both years and the lagoon often suffered from low dissolved oxygen and elevated temperature conditions in the bottom saline layer especially in the upper saline reaches away from tidal cooling.

Such environmental conditions and population declines suggest the potential for fish kills occurring. Only in 2006, however, did I observe evidence of a fish kill. On September 08, 2006, three to four days after a breaching event, I observed numerous dead threespine stickleback stranded on dewatered portions of the beach. I also observed numerous dead threespine stickleback and detected hydrogen sulfide odors in the downstream (Stations \#1-3) portion of the lagoon. Whether steelhead were killed during this breaching and or other breaching events is unknown. However, killing by stranding during the dewatering event or by toxicity (low dissolved oxygen and high hydrogen sulfide concentrations) is a possible explanation for the substantial reduction in the steelhead population. Additionally, if this breaching event directly or indirectly (due to low dissolved oxygen) reduced aquatic invertebrates, the reduced food for steelhead could also possibly explain the apparent population decline and slower growth, especially for age $0+$ fish. Food habits and macroinvertebrate abundance were not investigated in this study so the impact of these factors on the steelhead population is unknown. Fish kills have also been reported to occur nearly annually since 1995 at nearby Pescadero Creek lagoon in conjunction with an artificial breach (Sloan 2006).

Smaller age $0+$ size in 2006 could also be related to steelhead density in the lagoon. Bond (2006) and Hayes et al. (2008) in their studies of Scott Creek determined 
that steelhead growth varied among years and seemed to be density-dependent; the greater the steelhead density, the slower the growth. Additionally, Hayes et al. (2008) found in 3 years of studying Scott Creek lagoon that reduced steelhead size due to earlier sandbar closure and increased steelhead density could be offset by the greater length of time the sandbar was closed, allowing a longer period of high growth rates. At Soquel Creek lagoon, Santa Cruz County, Alley 2009 also found a similar association between steelhead abundance and growth rates when the sandbar was in place and the water column was completely fresh, attributing this to intraspecific competition (Alley 2009).

Despite apparent smaller size for age 0+ and greater population decline in 2006 than in the previous year, San Gregorio Creek lagoon was still a relatively productive habitat. Despite warm temperatures, food was apparently abundant and when food is abundant steelhead can de well even at warmer temperatures (Wurtsbaugh and Davis 1977b; Myrick and Cech 2005). However, the lagoon in both years might have been much more productive if the water column had fully destratified and had converted to freshwater. Smith (1990) reported that full-conversion to freshwater was observed to substantively increase abundance of macroinvertebrates as well as the growth and abundance steelhead in his studies of San Mateo and Santa Cruz County streams. At Soquel Creek lagoon in 2008, full-conversion to freshwater was observed in association with growth (median size $115 \mathrm{~mm}$ SL on September 27) and abundance $(7,071)$ of steelhead (Alley 2009). 
Patterns of Lagoon Utilization (Years 2005-2006 and April 2008)

The steelhead population was estimated to be 2,056 in fall 2005. By February and March 2006, most steelhead reared in the lagoon had out-migrated and few steelhead were present in the lagoon. By April 2006, age 1+ and 2+ steelhead smolts from stream habitat were beginning to be captured in the lagoon. By May 2006, age 0+ steelhead from stream habitat were beginning to be captured in the lagoon, but the catch was dominated by small (age 1+) fish. Larger and older smolts were apparently passing through the shallow, unproductive lagoon to the ocean, a pattern similar to that observed by Bond (2006) at shallow Scott Creek lagoon. By July 2006, the relative abundance of age $0+$ increased as did the population $(2,802)$ to the highest number of the year. The lag in appearance of age $0+$ in captures may have been due to delayed movement to the lagoon compared to age 1+ fish and also to size bias due to seine mesh size.

In both years, I found that juvenile steelhead were recruited from the stream into the lagoon as flows subsided prior to sandbar formation (highest recruitment occurred during June and July of 2006) and that recruitment substantially declined after July. In her work on Waddell Creek, Santa Cruz County, Davis (1995) also found that, despite adequate stream flows, little downstream or upstream movement by steelhead occurred after July. The specific environmental cues for fish to move into San Gregorio Creek estuary / lagoon are unclear.

Apparently, few, if any, steelhead left San Gregorio Creek lagoon to the ocean during the summer or fall of either year, despite the lagoon's being open from numerous artificial breaches. In his lagoon study, Smith (1990) also reported that despite artificial 
breaching of the sandbar in the summer and fall at San Gregorio Creek lagoon in 1986, juvenile steelhead remained in the lagoon. At Scott Creek lagoon, Hayes et al. (in review) found that after it rained in the late fall and just prior to the sandbar breach, a substantial portion of the juvenile steelhead migrated from the lagoon to upstream habitat then later outmigrated to the ocean. The cue triggering this upstream migration was reported to be unknown. Stream flows at San Gregorio Creek, however, during the summer and fall were likely too low to provide for upstream migration when artificial breaching occurred.

In 2006, out-migration of smolts from the lagoon was observed to occur between the period of November and February and most were gone by April. Extensive rainfall and high turbidity (secchi depth as low as $0.1 \mathrm{~m}$ ) during late winter and spring 2006 likely reduced the abundance of macroinvertebrate prey and also the ability of steelhead to visually locate prey, and could have triggered steelhead to leave the lagoon. This possible explanation is supported by Smith (1990) who found that fish left Waddell Creek lagoon, either upstream and / or to sea, after the lagoon became turbid in winter. Unlike April 2006, the lagoon conditions in April 2008 were apparently more productive: a deeper, salinity stratified lagoon behind a partially formed sandbar with a plankton bloom and abundant Neomysis. Fish reared in the lagoon the previous year were gone but smolts reared in upstream habitat were "plump" and showed large spring growth increments on their scales. 


\section{Steelhead Life Histories at San Gregorio Creek Watershed}

Five rearing strategies from 22 fish were observed, and most fish showed three different rearing strategies: 1 year in the lagoon only $(n=6-7) ; 1$ year in the stream and 1 year in the lagoon $(n=6-7)$; and 2 years in the stream $(n=5-7)$. These also produced the largest smolts based on back calculation to ocean entry, thereby showing that duration spent rearing in habitat types was inversely proportional to each habitat's productivity and fish size. At Scott Creek, Bond (2006) and Hayes et al. (2008) found similar life history strategies and growth, and Hayes et al. (2008) reported that steelhead utilized the same three rearing patterns within the Scott Creek watershed as I reported in San Gregorio Creek.

\section{Steelhead Population Over Time at San Gregorio Creek Estuary/Lagoon}

Coots (1973) trapped smolts and sampled San Gregorio Creek lagoon in 1971, and found that the peak of outmigration occurred in late April through early May and extended through June. In the early summer, Coots determined the steelhead population (those over $100 \mathrm{~mm}$ FL) in a very shallow lagoon to be 418 and concluded that most smolts $(7,000+)$ outmigrated through the estuary to the ocean, spending little time in the estuary / lagoon.

In his study at San Gregorio Creek lagoon / estuary during the years of 1985, 1986, and 1988, Smith (1990) determined that the steelhead population size varied among years. In 1985, when the lagoon destratified to freshwater and water quality conditions were good, the steelhead population was high and there was a unimodal size frequency at 
the end of the dry season. In 1986, when the lagoon was repeatedly artificially breached and water quality conditions were poor, the steelhead population was high $(10,713)$ but the length frequency was bimodal and fish were smaller. In the drought of 1988, when the lagoon was brackish, warm and had dissolved oxygen problems, the steelhead population was low (only 50).

\section{Steelhead Physiology and the Importance of Lagoons}

My results, in addition to those of Smith (1990), Cannata (1998), Bond (2006), Hanson (2008), Hayes et al. (2008), and Alley (2009) indicate that estuaries / lagoons may fill in an important productivity gap for southern range watersheds that lack the flows of northern range watersheds. In their review of steelhead age throughout the West coast, Withler (1966) and Busby et al. (1996) reported a general cline in freshwater age and life history strategies of steelhead from northern to southern latitudes, finding that northern latitude steelhead spent more time rearing in freshwater streams and had lower growth rates than did their counterparts in the south.

Bond (2006) showed at the Scott Creek watershed that the larger lagoon-reared steelhead have a survival advantage and comprised $85 \%$ of the adults returning to the watershed, despite the fact that the lagoon is less than $5 \%$ of the watershed. He further questioned the viability of steelhead populations in Central California watersheds that lack lagoons, and noted that lagoon-reared steelhead smolts are similar in size to the large fish in the northern latitudes streams (Ward et al. 1989; Lohr and Bryant 1999). This mid to late summer productivity at Scott Creek lagoon was high despite the unproductive 
conditions during the spring when the water level was low. At Scott Creek estuary during the spring, shallow conditions provided minimal feeding habitat and no transition zone (Hoar 1976; Healey 1982) for the small fish from the upper watershed to grow and adjust to saltwater in shallow estuarine habitat. Like that of Scott Creek, the estuary of San Gregorio was shallow and provided minimal feeding habitat and no transition zone during the wet springs of 2005 and 2006. However, unlike that of Scott Creek, the San Gregorio Creek estuary during the dry spring of 2008 was deep, productive, and provided a transition zone.

My data, in addition to that of Smith (1990), Cannata (1998), Bond (2006), Hanson (2008), Hayes et al. (2008), and Alley (2009) demonstrate the importance of maximizing steelhead productivity to ensure juvenile-to-adult survival and thus the ultimate recovery of the species. To do this, one should take a close look at the species' regional adaptations and implement restoration actions that maximize this species' growth and survival.

\section{Management Implications: Artificial Breaching}

On the California coast, artificial breaching of lagoon sandbars frequently occurs. This is done for a variety of reasons, often not accomplishing the intended goals: reducing saltwater influence or acquiring irrigation water; allowing public access to beaches; creation of surf break; allowing salmonid migration; having "fun" draining the lagoon; etc. Besides causing poor water quality conditions for steelhead rearing during the summer and fall, fish kills have been associated with artificial breaching events 
(Pescadero Creek and San Gregorio Creek lagoons), and artificial breaching is known to completely drain the impounded water (Scott Creek lagoon) in a few minutes after the event, stranding fish and presenting a safety risk to human beach goers (Smith 2007). In his comparison of steelhead life histories in watersheds with and without lagoons, Hanson (2008) showed that juvenile steelhead migrated downstream at generally younger ages and smaller sizes in systems with lagoons than in those watersheds without lagoons. According to Hanson, lagoons allowed for this earlier migration by providing an environment for steelhead to put on enough growth before outmigrating to the ocean or by providing for rearing in the lagoon an additional year. Conversely, in watersheds without lagoons, he found that juveniles reared in the stream habitat longer to reach appropriate size for survival thereby requiring smoltification to occur at an older age. Development of estuaries/lagoons has degraded habitat, and development of watersheds has made maintaining adequate stream rearing habitat, especially for prolonged periods of time, more difficult. This has increased the relative importance of estuary/lagoons as transition and rearing habitats.

I recommend that lagoon property owners and fisheries managers gain a better understanding as to why their lagoons are being breached, and then implement preventative measures, including prominent explanatory signs and enforcement.

At San Gregorio Creek lagoon in 2006, the lagoon mouth formed at the north end of the beach, blocking public access from the parking lot to the beach. Preventative measures (e.g. building a sand berm along the cliff prior to lagoon formation) could be implemented to allow public access, and thus reduce the need to breach. In areas where 
flood control is an issue, one could construct a flume that runs from the deepest area of the lagoon through a built up sandbar, as is operated by the City of Capitola on Soquel Creek, Santa Cruz County (Habitat Restoration Group 1990; Alley 2009). The flume, along with a stilling well, can collect saltwater at the bottom of the water column when the surface water elevation reaches a specified elevation, allowing quicker freshwater conversion as well as flood control. 


\section{References}

Alley, D. W. 2009. Soquel Creek Lagoon Monitoring Report, 2008. Prepared by DW. Alley and Associates for the City of Capitola.

Barnhart, R. 1986. Species profiles: life histories and environmental requirements of coastal fishes and invertebrates (Pacific Southwest), - steelhead. U. S. Fish Wildlife Biological Report 82 (11.60). U. S. Army Corps of Engineers. TREL 82-4. 21 pages.

Bisson, P. A., J. L. Nielsen, and J. W. Ward. 1988. Summer production of coho salmon stocked in Mount St. Helens streams 3-6 years after the 1980 eruption. Transactions of the American Fisheries Society. 117:322-335.

Bond, M. H. 2006. The importance of estuarine rearing to central California steelhead (Oncorhynchus mykiss) growth and marine survival. Master's thesis. University of California, Santa Cruz.

Busby, M. M. and R. A. Barnhart. 1995. Potential food sources and feeding ecology of juvenile fall Chinook salmon in California's Mattole River lagoon. California Department of Fish and Game Bulletin. 81 (4): 136-146.

Busby, P. J., T. C. Wainwright, G. J. Bryant, L. J. Lierheimer, R. S. Waples, F. W. Waknitz, and I. V. Lagomarsino. 1996. Status review of the West Coast steelhead from Washington, Idaho, Oregon, and California. NOAA Technical Memorandum NMFS-NWFSC-27. 
Cannata, S. P. 1998. Observations of steelhead trout (Oncorhynchus mykiss), coho salmon (Oncorhynchus kisutch) and water quality of the Navarro River estuary / lagoon May 1996 to December 1997. Draft report prepared for the Humboldt State University Foundation, Arcata, California.

Carlander, K. D. 1969. Handbook of freshwater fishery biology: volume 1. Iowa State University Press, Ames, IA. 752 pp.

Connolly, P. J., and J. H. Peterson. 2003. Bigger is not always bigger for overwintering young-of-year steelhead. Transactions of the American Fisheries Society 132: 262-274.

Coots, M. 1973. A study of juvenile steelhead, Salmo gairdnerii gairnerii Richardson, in San Gregorio Creek and Lagoon, San Mateo County, March through August, 1971. California Department of Fish and Game, Anadromous Fisheries Branch Administrative Report No. 73-4.

Davis, Lanette D. 1995. Age determination of steelhead trout (Oncorhynchus mykiss) in microhabitats of a small central California coastal stream using otolith microstructural analysis. M. S. Thesis, San Jose State University. 38 pp.

Habitat Restoration Group. 1990. Soquel Creek Lagoon Management Plan. Prepared for the City of Capitola.

Hanson, C. V. 2008. Influence of Lagoon Habitat on Steelhead Life History Variation. Ecology and Evolutionary Biology. Santa Ecology and Evolutionary Biology. Santa Cruz, CA, University of California, Santa Cruz: 60. 
Hartman, G. F. 1965. The role of behavior in the ecology and interaction of underlying coho salmon (Oncorhynchus kisutch) and steelhead trout (Salmo gairdneri). Journal of the Fisheries Research Board of Canada. 22(4): 1035-1081.

Harvey, B. C. and R. J. Nakamoto. 1996. Effects of steelhead density on growth of coho salmon in a small coastal California stream. Transactions of the American Fisheries Society. 125(2): 237-243.

Hayes, S. A., C. V. Hanson, M. H. Bond, D. E. Pearse, A. Jones, J. C. Garza, R. B. MacFarlane. In Review. Should I stay or should I go? The influence of genetics and physiology on habitat use and emigration by resident and anadromous Oncorhynchus mykiss. Canadian Journal of Fisheries and Aquatic Sciences.

Hayes, S. A., M. H. Bond, C. V. Hanson, E. V. Freund, J. J. Smith, E. C. Anderson, A. J. Amman, and R. B. MacFarlane. 2008. Steelhead growth in a small central California watershed: upstream and estuarine rearing patterns. Transactions of the American Fisheries Society. 137: 114-128.

Healey, M. C. 1982. Juvenile Pacific salmon in estuaries: the life support system. Pages 315-341 in V. S. Kennedy, editor. Estuarine comparisons. Academic Press, New York.

Hoar, W. S. 1976. Smolt transformation—evolution, behavior, and physiology. Journal of the Fisheries Research Board of Canada. 33:1233-1252.

Johnson, J. A., D. P. Liscia, and D. M. Anderson. 1986. The seasonal occurrence and distribution of fish in the Umqua estuary, April 1977 through January 1986. Southwest Region, Oregon Department of Fish and Wildlife. 
Lohr, S. C., and M. D. Bryant. 1999. Biological characteristics and population status of steelhead (Oncorhynchus mykiss) in Southwest Alaska. General technical report PNW-GTR-407, USDA, Forest Service, Juneau, Alaska.

MacDonald J. S., C. D Levings., C. D. McAllister, U. H. M. Fagerlund, and J. R. McBride. 1988. A field experiment to test the importance of estuaries for Chinook salmon (Oncorhynchus tshawytscha) survival: short-term results. Canadian Journal of Fisheries and Aquatic Sciences. 45: 1366-1377.

Martin, J. A. 1995. Food habits of some estuarine fishes in a small, seasonal central California lagoon. Masters Thesis. San Jose State University, San Jose, California.

McCarthy, S. G., J. J. Duda, J. M. Emlen, G. R. Hodgson, G. R. Hodgson, D. A. Beachamp. 2009. Linking Habitat Quality with Trophic Performance of Steelhead along forest gradients in the South Fork Trinity River wateshed, California. Transactions of the American Fisheries Society. 138:506-521.

McMahon, T. E., and L. B. Holtby. 1992. Behavior, habitat use, and movements of coho salmon (Oncorhynchus kisutch) smolts during seaward migration. Canadian Journal of Fisheries and Aquatic Sciences. 49: 1478-1485.

Myrick, C. A., and J. J. Cech. 2005. Effects of temperature on the growth, food consumption, and thermal tolerance of age- 0 Nimbus-strain steelhead. North American Journal of Aquaculture 67:324-330.

Moyle, P. B. 2002. Inland fishes of California, revised and expanded. University of California Press, Berkeley, California, USA. 
O'Neil Surf Shop. 2004. High and Low Tides of 2005. Wilkins Printing, Atascadero, California.

O'Neil Surf Shop. 2005. High and Low Tides of 2006. Wilkins Printing, Atascadero, California.

Pritchard, D. W. 1952. Estuarine hydrograpghy. Advances in Geophysics, Volume 1. Edited by H. E. Landsberg. Geophysics Research Directorate, Air Force Cambridge Research Center. Academic Press, Inc., New York, USA, 1952

Ricker, W. E. 1975. Computation and interpretation of biological statistics of fish populations. Journal of the Fisheries Research Board of Canada, Bulletin 191. $382 \mathrm{pp}$.

Robinson, M. A. 1993. The distribution and abundance of benthic and epibenthic macroinvertebrates in a small, seasonal central California lagoon. Masters Thesis. San Jose State University, San Jose, California.

Shapovalov, L., and Taft, A. C. 1954. The life histories of the steelhead rainbow trout (Salmo gairdneri gairdneri) and Silver salmon (Oncorhynchus kisutch) with special reference to Waddell Creek, California and recommendations regarding their management. California. Department of Fish \& Game Bulletin. 98:303 p.

Smith, J. J. 1990. The effects of sand bar formation and inflows on aquatic habitat and fish utilization of Pescadero, San Gregorio, Waddell, and Pomponio Creek Estuary/Lagoon Systems. Interagency Agreement 84-04-0324, Trustees California State University and California Department of Parks and Recreation. 
Smith, J. J. September 2007. Sandbar formation, inflows, and ecology of Central California lagoons. American Fisheries Society Annual Meeting.

Sloan, R. M. 2006. Ecological investigations of a fish kill in Pescadero Lagoon, California. Master's Thesis. San Jose State University, San Jose, California.

Tipping, J. M. 1997. Effect of smolt length at release on adult returns of hatchery reared steelhead. The Progressive Fish Culturist. 59: 310-311.

United State Geological Survey. 2005. Stream Flow Data. http://waterdata.usgs.gov.

United State Geological Survey. 2006. Stream Flow Data. http://waterdata.usgs.gov.

Ward, B. R., P. A. Slaney, A. R. Facchin, and R. W. Land. 1989. Size-based survival in steelhead trout (Oncorhynchus mykiss): Back-calculated lengths from adults' scales compared to migrating smolts at the Keogh River, British Columbia. Canadian Journal of Fisheries and Aquatic Sciences. 46: 1853-1858.

Watson, F., W. Newman, T. Anderson, S. Alexander, and D. Kozlowski. 2001. Winter water conditions of the Carmel and Salinas Lagoons, Monterey, California: 2000/2001. The Watershed Institute. Report No. WI-2001-01.

Welsh, H. H., G. R. Hodgson, and B. C. Harvey. 2001. Distribution of juvenile coho salmon in relation to water temperatures in tributaries of the Mattole River, California. North American Journal of Fisheries Management 21: 464-470.

Withler, R. E. 1966. Variability in life history characteristics of steelhead trout (Salmo gairdneri) along the Pacific coast of North America. Journal of the Fisheries Research Board of Canada 23:365-393. 
Wurtsbaug, W. A., and G. E. Davis. 1977a. Effects of fish size and ration level on the growth and food conversion efficiency of rainbow trout, Salmo gairdneri.

Richardson. Journal of Fish Biology 11:99-104.

Wurtsbaug, W. A., and G. E. Davis. 1977b. Effects of temperature and ration level on the growth and food conversion efficiency of Salmo gairdneri. Richardson. Journal of Fish Biology 11:87-98.

Zedonis, P. 1992. The biology of juvenile steelhead (Oncorhynchus mykiss) in the Mattole River estuary/lagoon. Master's Thesis. Humboldt State University, Arcata, California. 
Table 1. Timeline of sandbar closure in years 2005 and 2006 in San Gregorio Creek lagoon, San Mateo County.

\begin{tabular}{|c|c|c|}
\hline $\begin{array}{l}\text { Actual Dates } \\
\text { Observed Closed }\end{array}$ & $\begin{array}{l}\text { Amount of Time } \\
\text { Closed }\end{array}$ & Breach Method / Direction of Channel Opening \\
\hline \multicolumn{3}{|r|}{ (2) } \\
\hline 3-Aug-05 & $<24$ hours & $\begin{array}{l}\text { Trench dug in straight shot direction to the ocean; approximately equidistant from bluffs located at the } \\
\text { north and south; lagoon drained when it reached surface elevation of trench. }\end{array}$ \\
\hline 5-Aug-05 & $<3$ days & $\begin{array}{l}\text { Trench dug in straight shot direction to the ocean; approximately equidistant from bluffs located at the } \\
\text { north and south. }\end{array}$ \\
\hline 14-Sep-05 & approx. 10 days & $\begin{array}{l}\text { Trench dug in straight shot direction to the ocean; approximately equidistant from bluffs located at the } \\
\text { north and south. }\end{array}$ \\
\hline 30-Sep-05 & approx. 13 days & $\begin{array}{l}\text { Trench dug in straight shot direction to the ocean; approximately equidistant from bluffs located at the } \\
\text { north and south. }\end{array}$ \\
\hline 14-Oct-05 & approx. 13 days & $\begin{array}{l}\text { Trench dug in straight shot direction to the ocean; approximately equidistant from bluffs located at the } \\
\text { north and south. }\end{array}$ \\
\hline 11-Nov-05 & approx. 15 days & Drained at south end of breach; unknown whether breach was natural (recent rainfall?) or artificial. \\
\hline 18-Nov-05 & Unknown & Low elevation sandbar that is intermittently open at high tides. \\
\hline $\begin{array}{l}\text { Intermittently } \\
\text { opening through } \\
\text { most of December }\end{array}$ & Unknown & Low elevation sandbar that is intermittently open at high tides. \\
\hline \multicolumn{3}{|r|}{ ( } \\
\hline 24-Aug-06 & approx. 5 days & Lagoon blocking beach access; notches in sandbar drained lagoon at north end of beach. \\
\hline 4-Sep-06 & $<24$ hours & $\begin{array}{l}\text { Lagoon blocking beach access; artificially drained at north end of beach; numerous dead stickleback at } \\
\text { dewatered area and near bridge abutments. }\end{array}$ \\
\hline 20-Sep-06 & $\begin{array}{l}\text { approx. } 14 \text { days } \\
\text { (intermittent closure) }\end{array}$ & $\begin{array}{l}\text { Lagoon blocking beach access; low elevation sandbar caused by Labor Day weekend's breach (and } \\
\text { possibly rain) caused intermittent status and breach. }\end{array}$ \\
\hline 19-Oct-06 & $\begin{array}{l}\text { approx. } 10 \text { days } \\
\text { (intermittent closure) }\end{array}$ & $\begin{array}{l}\text { Lagoon blocking beach access; low elevation sandbar caused by Labor Day weekend's breach caused } \\
\text { intermittent status and breach. }\end{array}$ \\
\hline 2-Nov-06 & $\begin{array}{l}\text { approx. } 7 \text { days } \\
\text { (intermittent closure) }\end{array}$ & $\begin{array}{l}\text { Lagoon blocking beach access; low elevation sandbar caused by Labor Day weekend's breach caused } \\
\text { intermittent status and breach. }\end{array}$ \\
\hline 17-Nov-06 & $<$ one week & $\begin{array}{l}\text { Lagoon blocking beach access; low elevation sandbar caused by Labor Day weekend's breach caused } \\
\text { intermittent status and breach. }\end{array}$ \\
\hline $\begin{array}{l}\text { Weak opening } \\
\text { until 20-Dec-06 } \\
\text { (Closed) }\end{array}$ & Unknown & $\begin{array}{l}\text { Lagoon blocking beach access; low elevation sandbar caused by Labor Day weekend's breach caused } \\
\text { intermittent status and breach. }\end{array}$ \\
\hline
\end{tabular}


Table 2. Back-calculation of standard lengths ( $\mathrm{mm}$ ) at last freshwater annulus from successful adult steelhead collected on April 18, 2008 in San Gregorio Creek lagoon, San Mateo County.

\begin{tabular}{|c|c|c|c|c|c|c|c|c|}
\hline $\begin{array}{l}\text { Rearing } \\
\text { Habitat } \\
\text { Utilized }\end{array}$ & $\begin{array}{c}\text { Rearing } \\
\text { Duration } \\
\text { Per Habitat } \\
\text { Type } \\
\text { (years) }\end{array}$ & $\begin{array}{c}\text { Number } \\
\text { Steelhead }\end{array}$ & $\begin{array}{c}\text { Back-Calc Size } \\
1 \text { yr Stream } \\
\text { Mean SL (mm) }\end{array}$ & $\begin{array}{c}\text { Back-Calc Size } \\
2 \text { yrs Stream } \\
\text { Mean SL (mm) }\end{array}$ & $\begin{array}{c}\text { Back-Calc Size } \\
3 \text { yrs Stream } \\
\text { Mean SL (mm) }\end{array}$ & $\begin{array}{c}\text { Back-Calc Size } \\
\text { 1yr Stream + } 1 \text { yr } \\
\text { Lagoon } \\
\text { Mean SL (mm) } \\
\end{array}$ & $\begin{array}{c}\text { Back-Calc Size } \\
1 \text { yr Lagoon } \\
\text { Mean SL (mm) }\end{array}$ & $\begin{array}{c}\text { Back-Calc Size } \\
\text { Ocean Entry } \\
\text { Mean SL (mm) }\end{array}$ \\
\hline \multirow[t]{2}{*}{$\begin{array}{l}\text { Stream } \\
\text { Only }\end{array}$} & 1 & 2 & $122 \pm 13.3$ & & & & & \\
\hline & $\begin{array}{l}2 \\
3\end{array}$ & $\begin{array}{c}5 \text { to } 7 \\
1\end{array}$ & & $\begin{array}{c}158 \pm 15.1 \text { to } \\
161 \pm 17.5\end{array}$ & 204 & & & \\
\hline $\begin{array}{l}\text { Stream } \\
\text { and } \\
\text { Lagoon }\end{array}$ & $\begin{array}{l}1 \text { year in } \\
\text { each }\end{array}$ & 6 to 7 & & & & $\begin{array}{c}197 \pm 34.5 \text { to } \\
205 \pm 29.5\end{array}$ & & \\
\hline $\begin{array}{l}\text { Lagoon } \\
\text { Only }\end{array}$ & 1 & 6 to 7 & & & & & $\begin{array}{l}181 \pm 37.2 \text { to } \\
195 \pm 13.4\end{array}$ & \\
\hline Total & & 22 & & & & & & $189 \pm 26.1$ \\
\hline
\end{tabular}

Total of 12-14 out of $22(55-64 \%)$ successful adults reared a substantial amount of time in lagoon. 
Table 3. Standard length ( $\mathrm{mm}$ ) of steelhead captured at Alpine Creek, San Gregorio Creek, and San Gregorio Creek lagoon in 2005-2006, as well as the mean back-calculated standard length at last freshwater annulus from successful adult steelhead collected on April 18, 2006 in San Gregorio Creek lagoon. All locations are within the San Gregorio Creek watershed, San Mateo County.

\begin{tabular}{|c|c|c|c|c|}
\hline Location of Steelhead Captured & $\begin{array}{c}\text { Date } \\
\text { Captured }\end{array}$ & Age & $\begin{array}{c}\text { Sample Size } \\
\mathbf{n}\end{array}$ & $\begin{array}{c}\text { Mean } \\
\text { Standard Length } \\
(\mathrm{mm})\end{array}$ \\
\hline \multirow[t]{3}{*}{ Alpine Creek } & 15-Nov-05 & $0+$ & 22 & $55 \pm 7.40$ \\
\hline & & $1+$ & 10 & $92 \pm 20.3$ \\
\hline & & $2+$ & NA & NA \\
\hline \multirow[t]{2}{*}{ San Gregorio Creek } & 15-Nov-05 & $0_{+}$ & 26 & $77 \pm 13.9$ \\
\hline & & $1+$ & 3 & $123 \pm 16.1$ \\
\hline \multirow[t]{3}{*}{ San Gregorio Creek lagoon } & 27-Oct-05 & $0+$ & 31 & $161 \pm 11.3$ \\
\hline & & $1+$ & 37 & $162 \pm 9.59$ \\
\hline & & $2+$ & 1 & $170 \pm 13.2$ \\
\hline \multirow[t]{3}{*}{ San Gregorio Creek lagoon } & 3-Nov-06 & $0+$ & 32 & $141 \pm 13.4$ \\
\hline & & $1+$ & 43 & $161 \pm 18.8$ \\
\hline & & $2+$ & 3 & $173 \pm 2.90$ \\
\hline $\begin{array}{l}\text { Back-Calculated Size at Ocean Entry } \\
\text { (Scales collected from adults on } 18 \text { April 2008) }\end{array}$ & -- & -- & 22 & $189 \pm 26.1$ \\
\hline
\end{tabular}




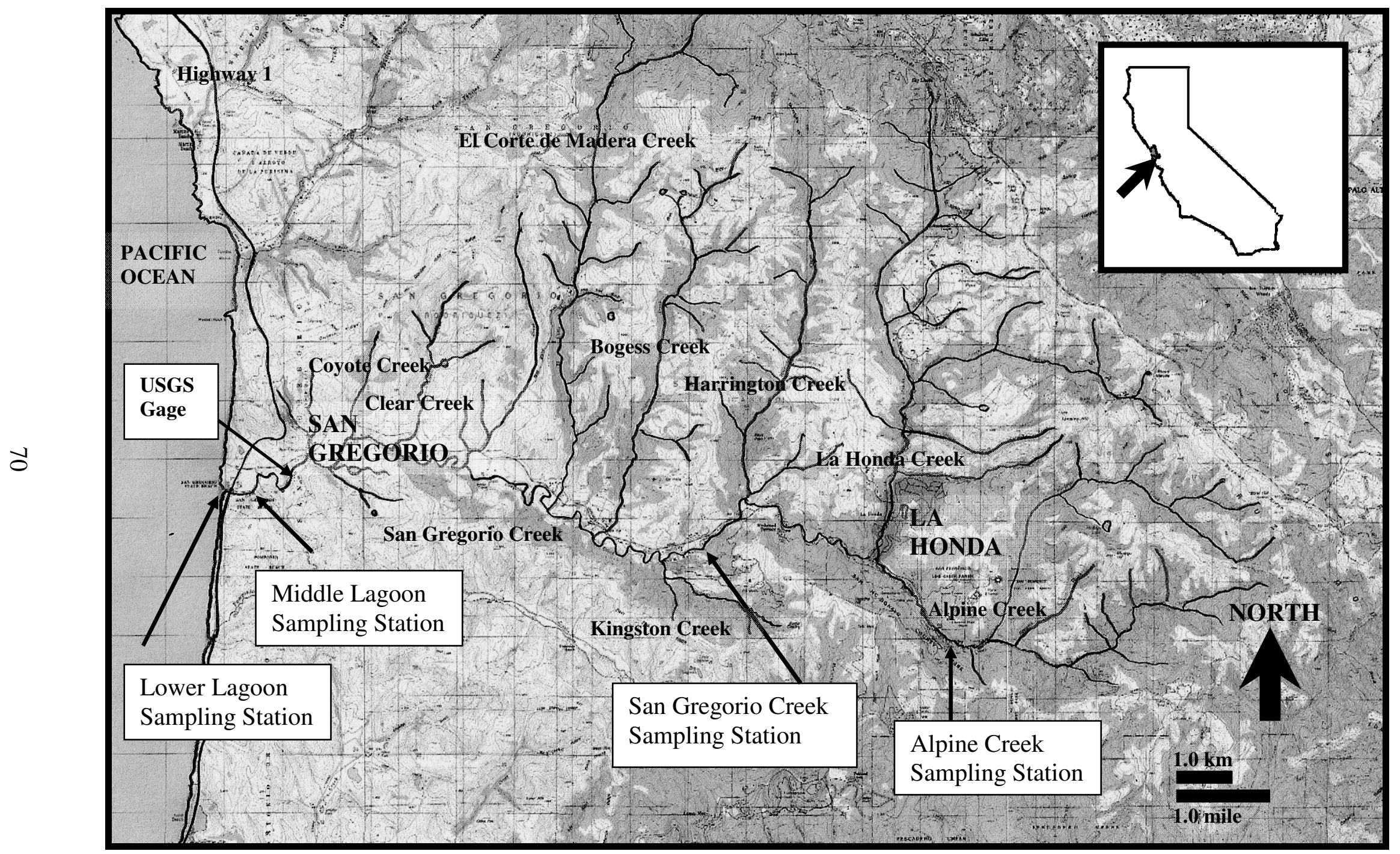

Figure 1

Fish sampling locations in the San Gregorio Creek watershed, San Mateo County (modified from map courtesy of MyTopo, Inc.). 


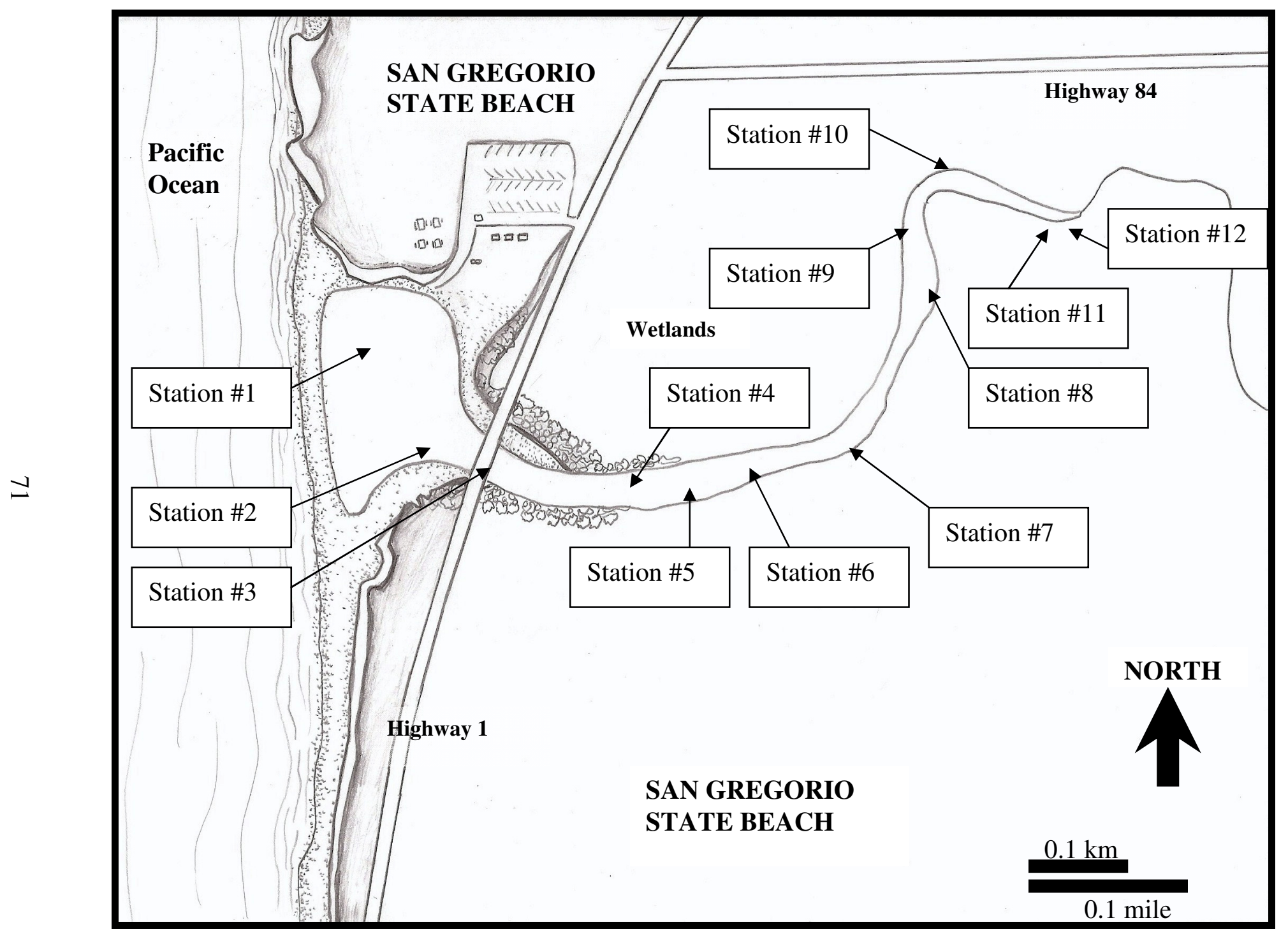

Figure 2. Water quality sampling locations at San Gregorio Creek lagoon, San Mateo County. 


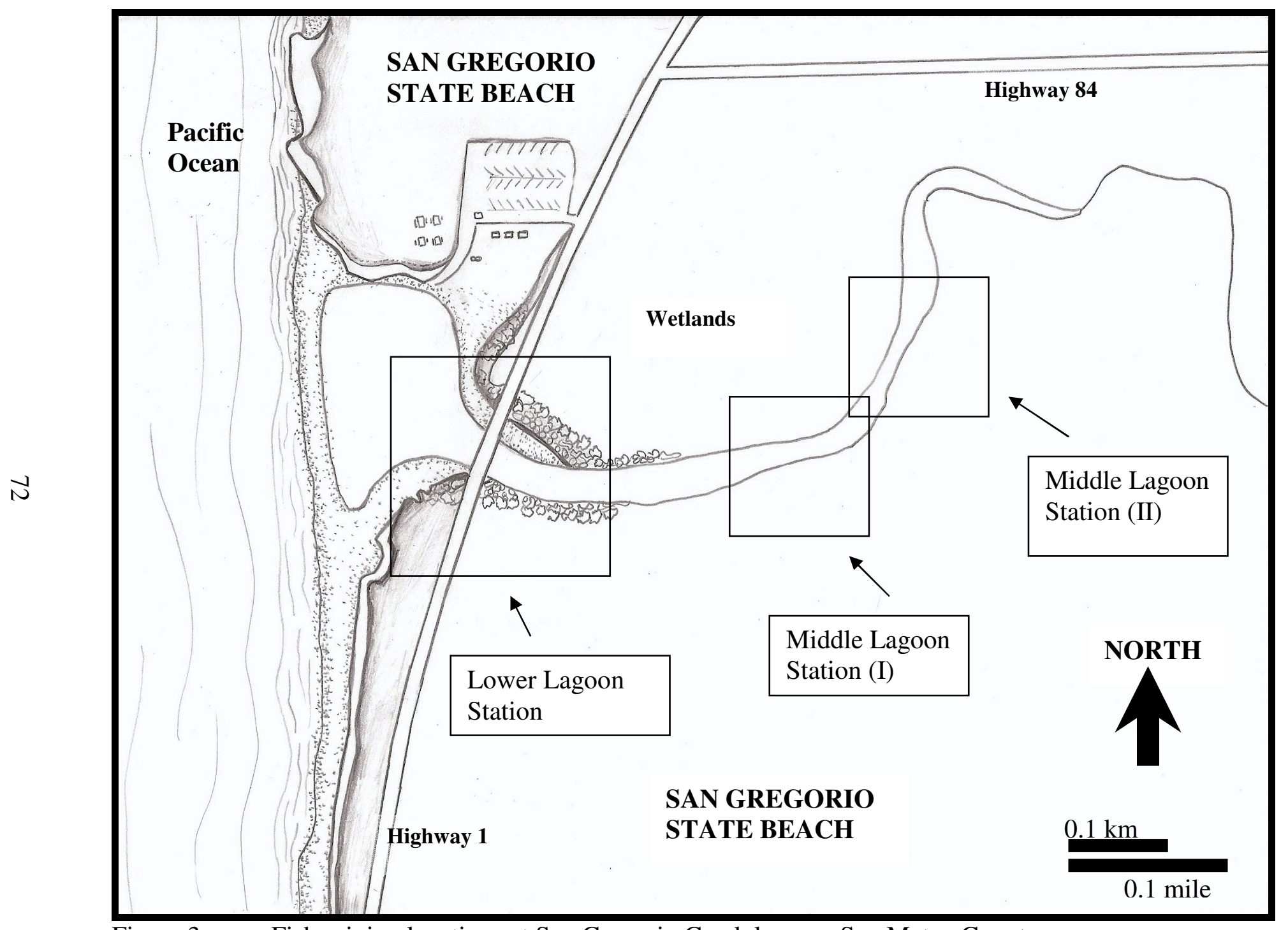

Figure 3. $\quad$ Fish seining locations at San Gregorio Creek lagoon, San Mateo County. 


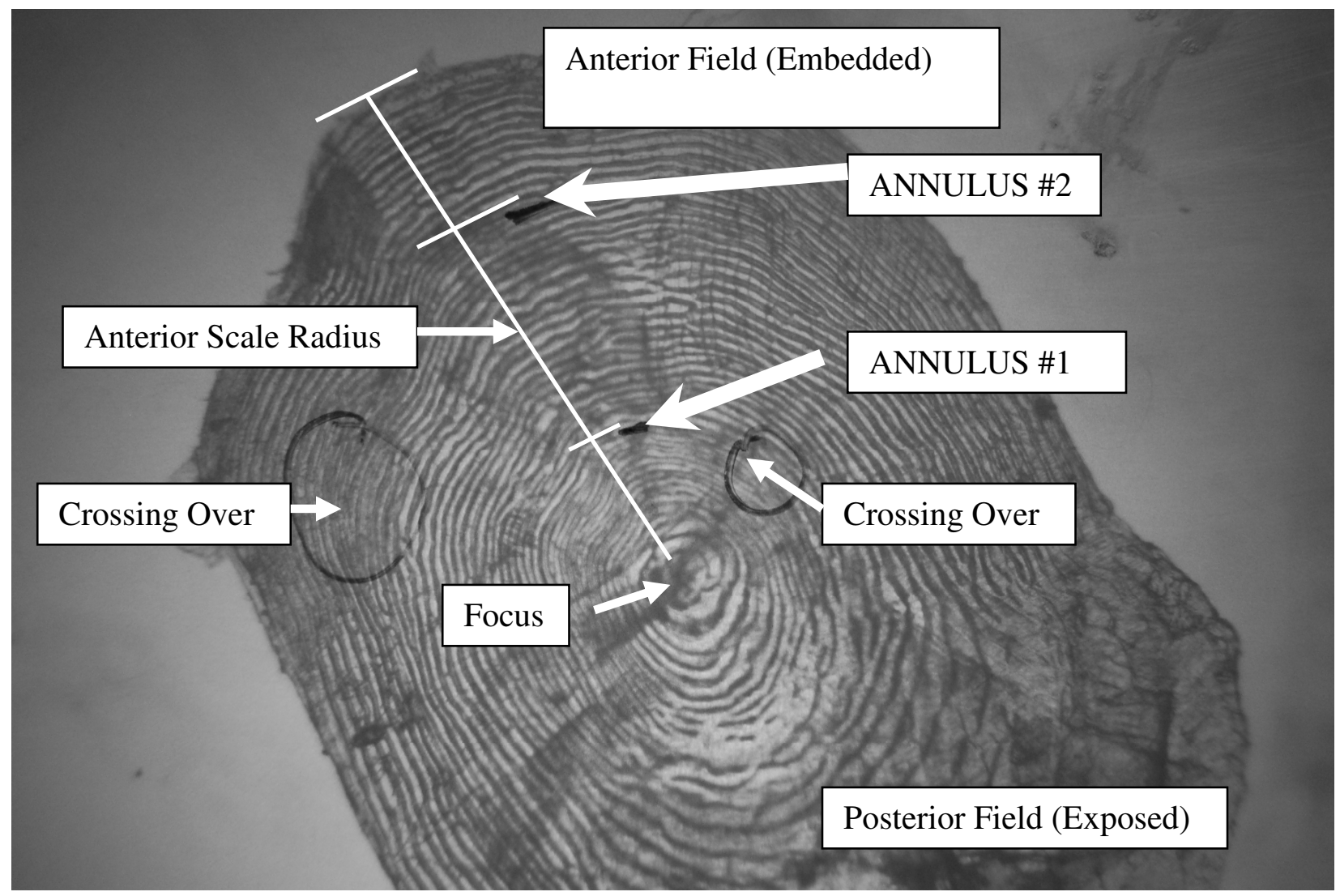

Figure 4. Example of interpretation of a steelhead scale from age 2+ smolt (modified from photo courtesy of Jerry Smith). 
a)

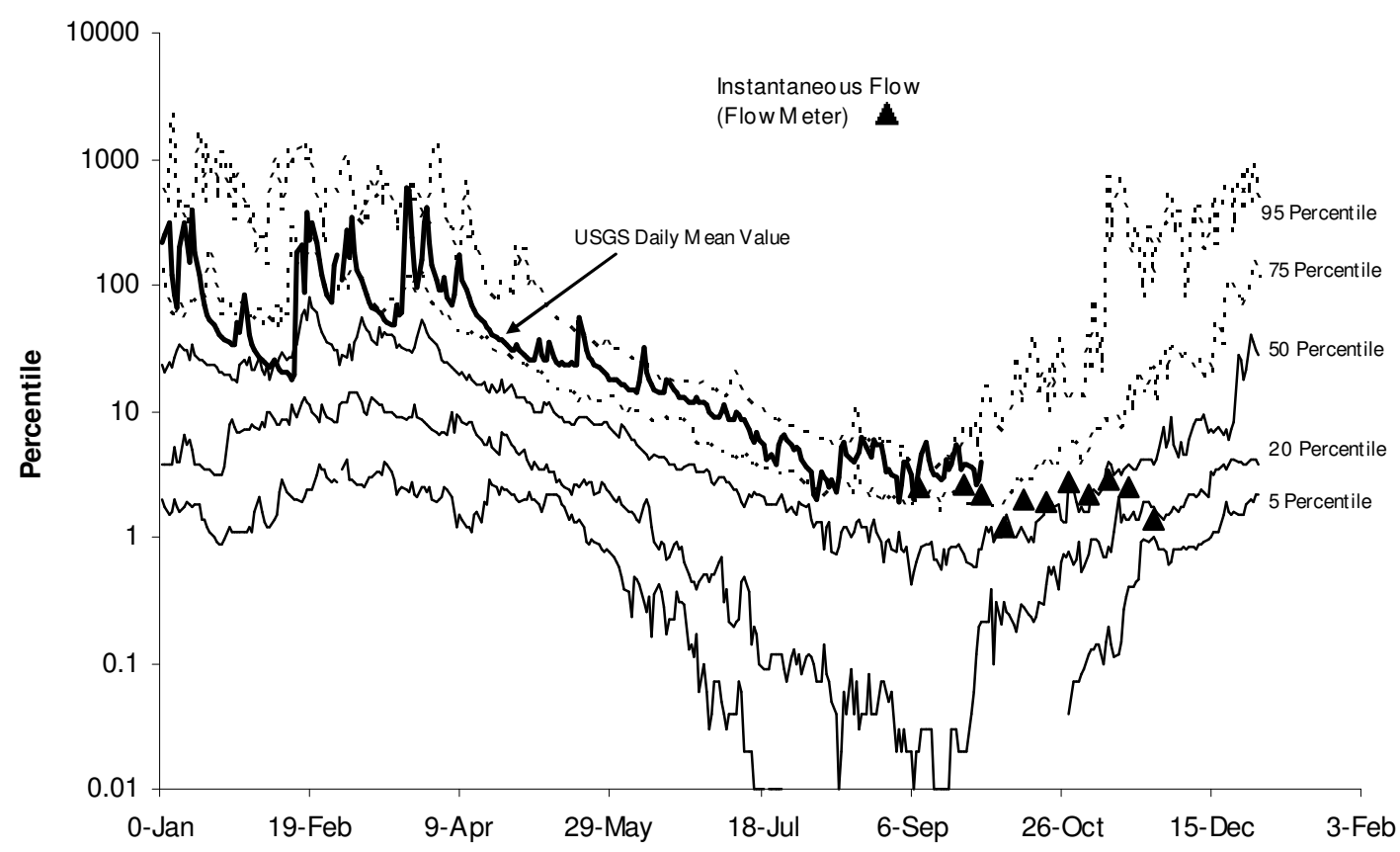

b)

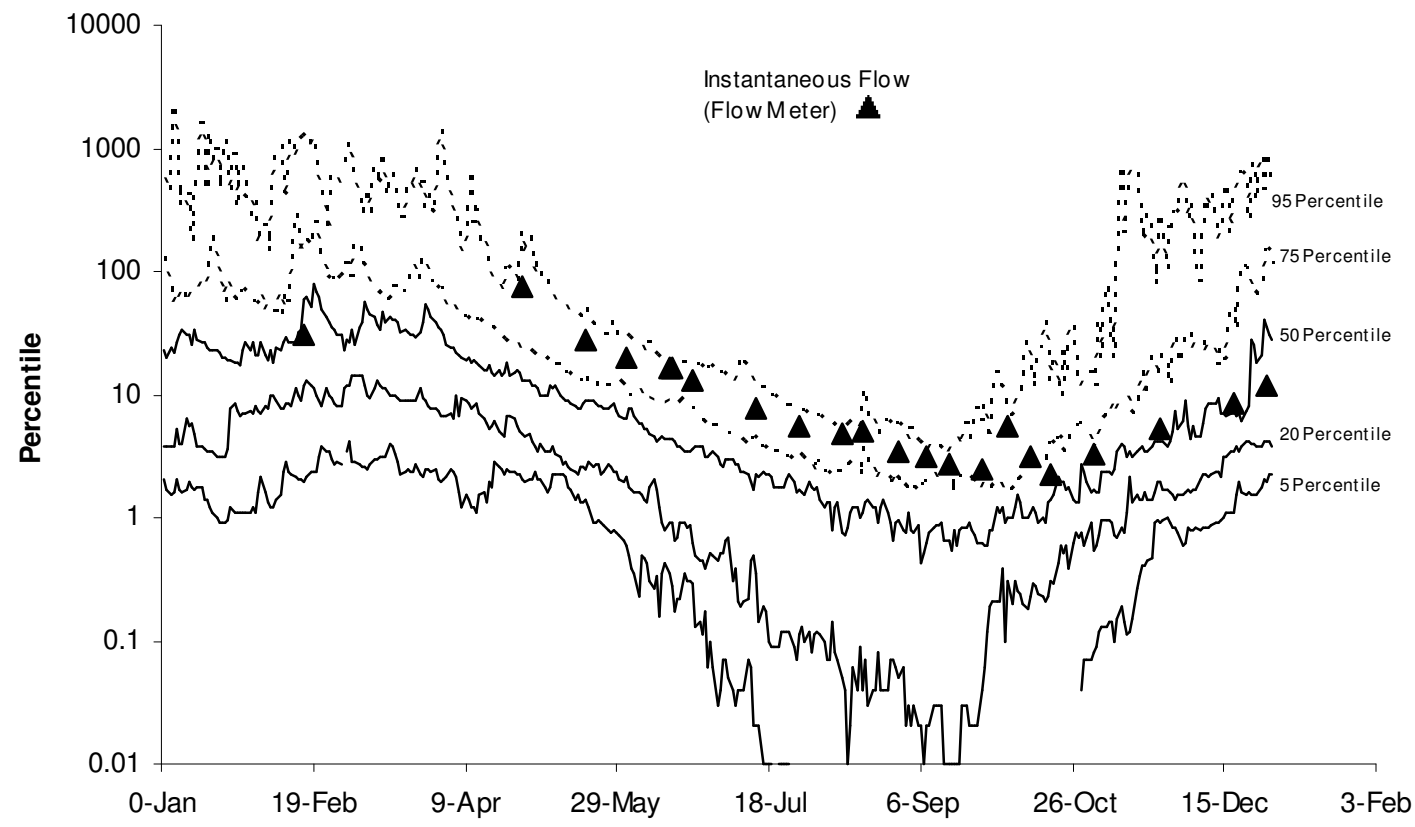

Figure 5. Flows and United States Geological Survey percentiles at the Stage Road bridge crossing during the years of (a) 2005 and (b) 2006 at San Gregorio Creek, San Mateo County. 
a)

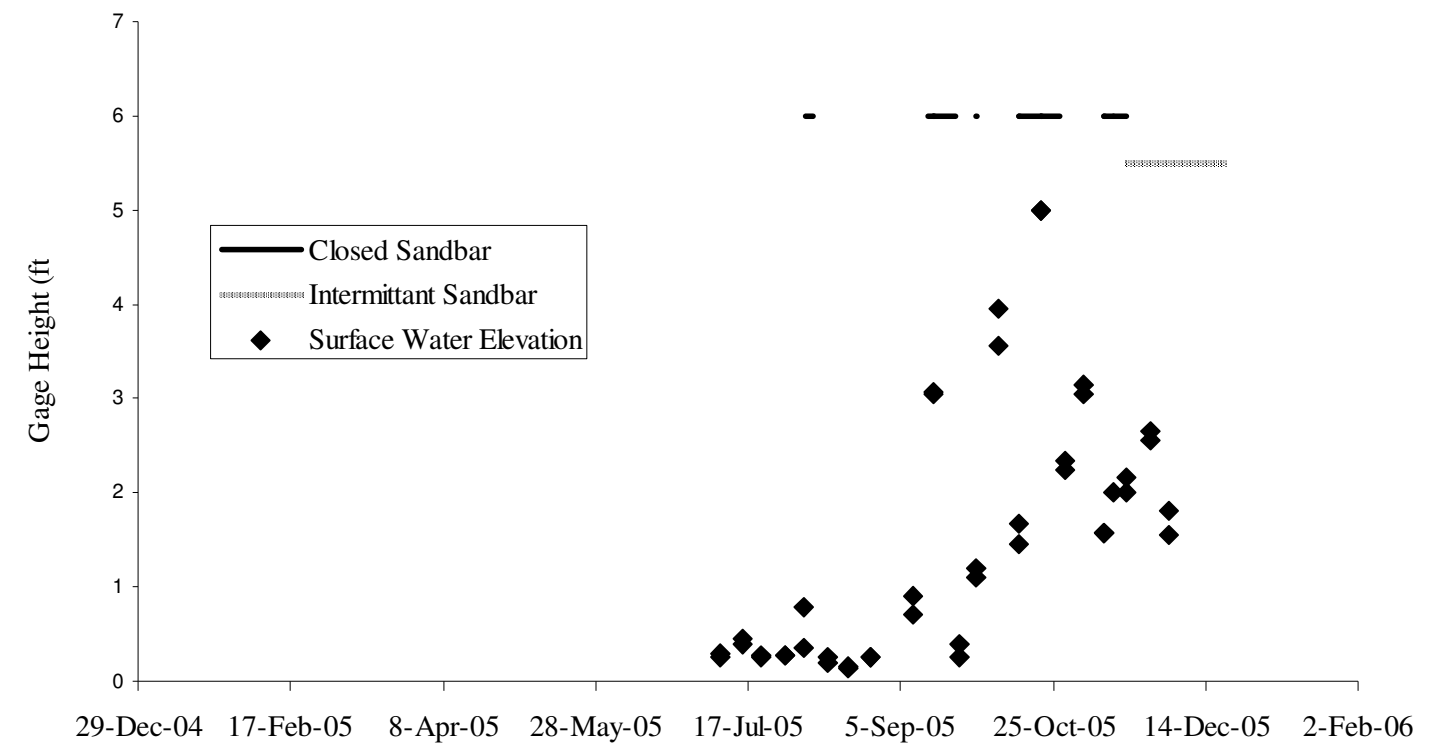

b)

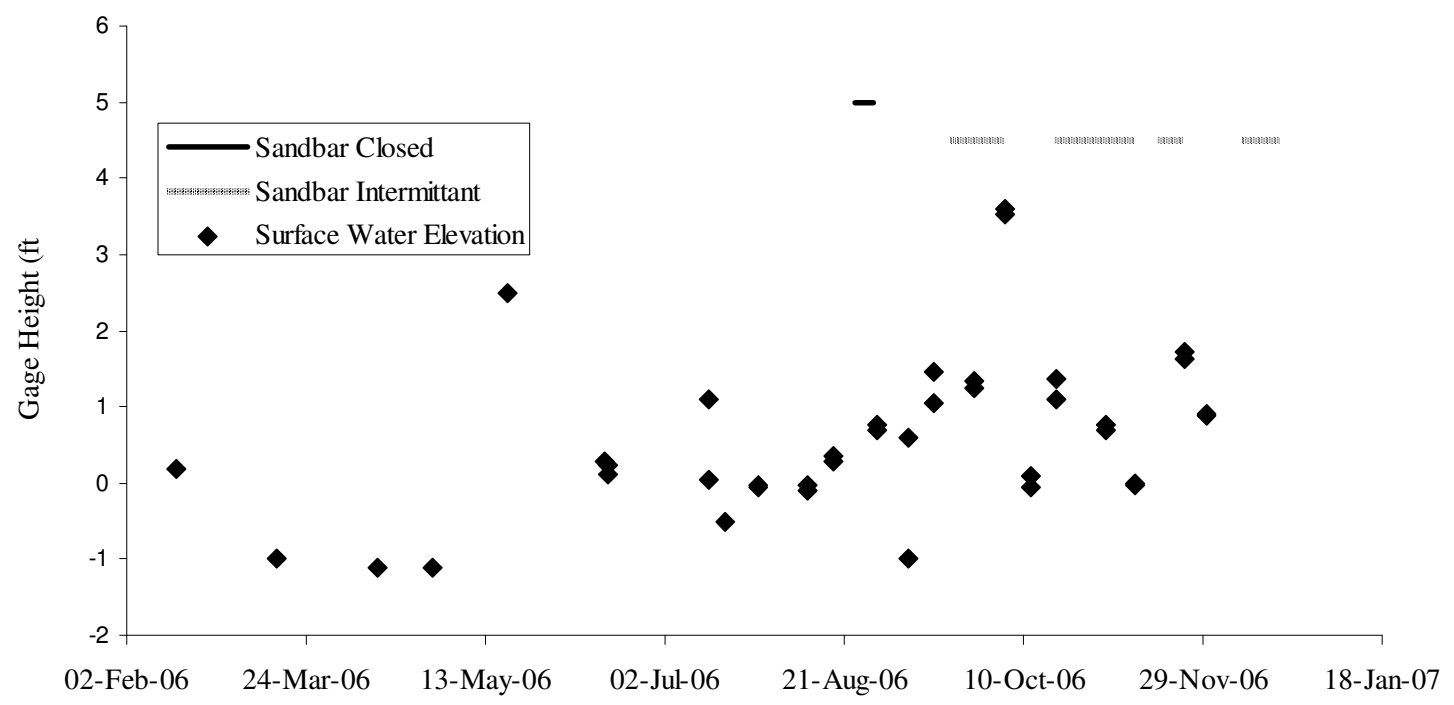

Figure 6. Observed Highway 1 gage height in year 2005 (a) and 2006 (b) at San Gregorio Creek lagoon, San Mateo County. Gage was arbitrarily placed and not surveyed. 
a)

June 17, 2005

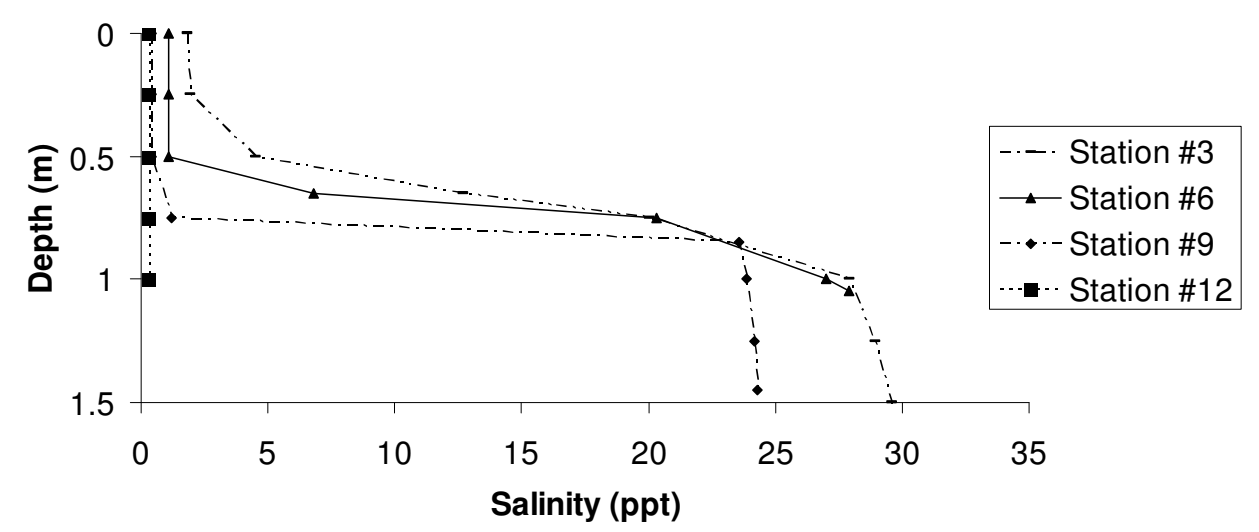

b)

July 15, 2005

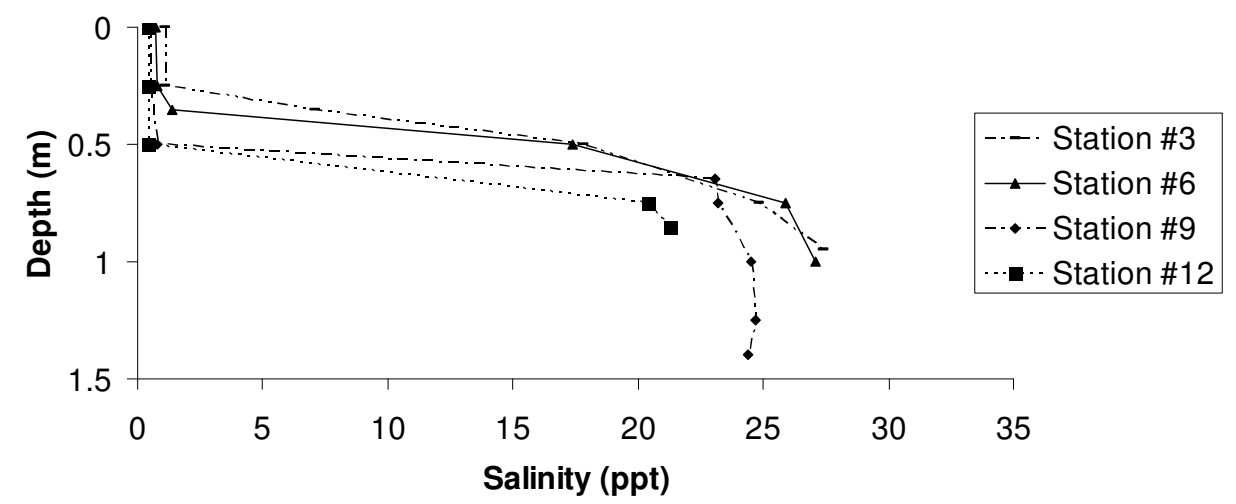

c)

July 29, 2005

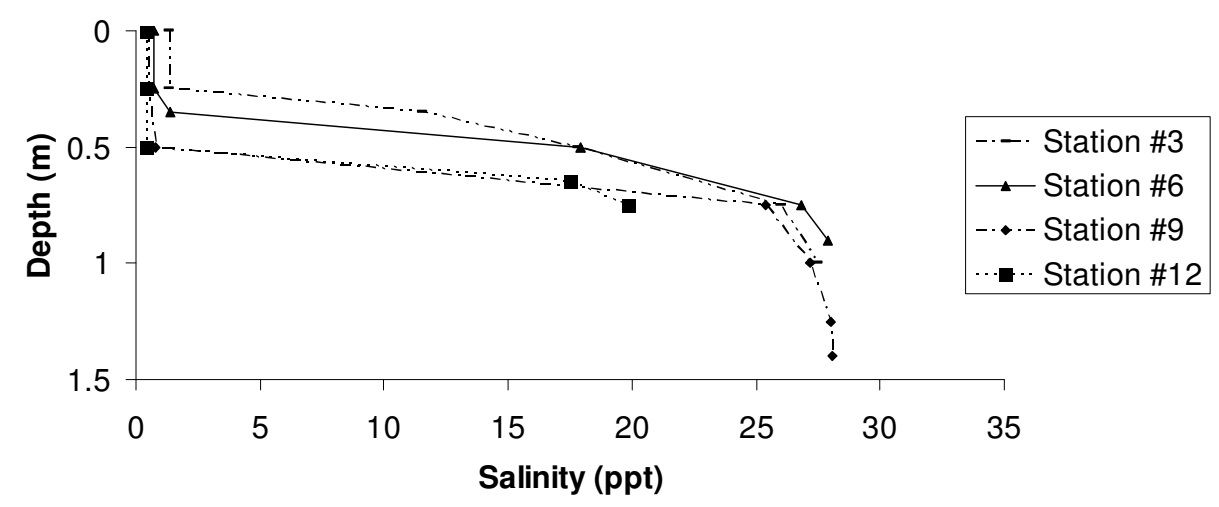

Figure 7. Salinity (ppt) at Stations \#3, 6, 9, and 12 on (a) June 17, (b) July 15, and (c) July 29, 2005 in San Gregorio Creek lagoon, San Mateo County. 
a)

August 04, 2005

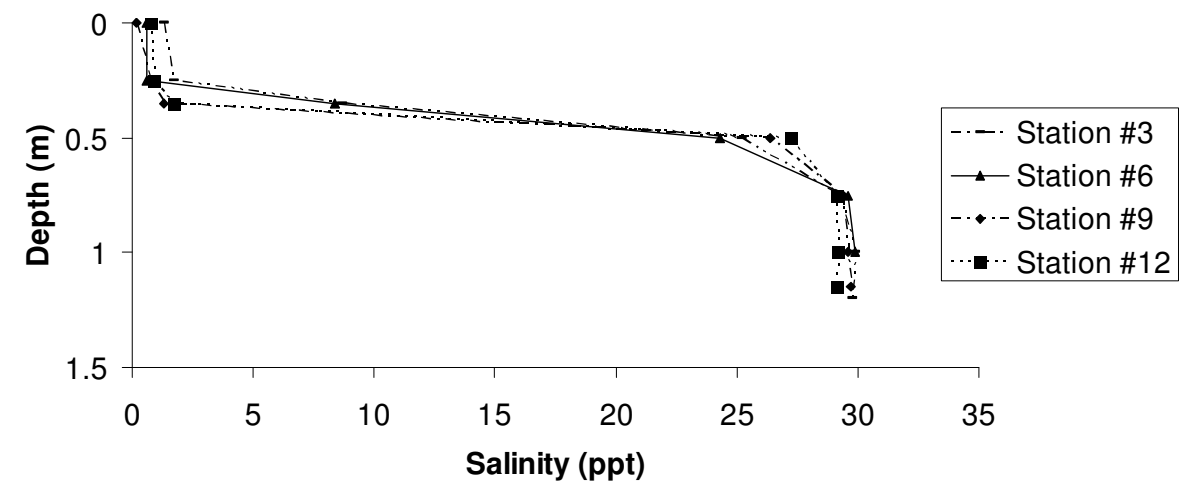

b)

August 12, 2005

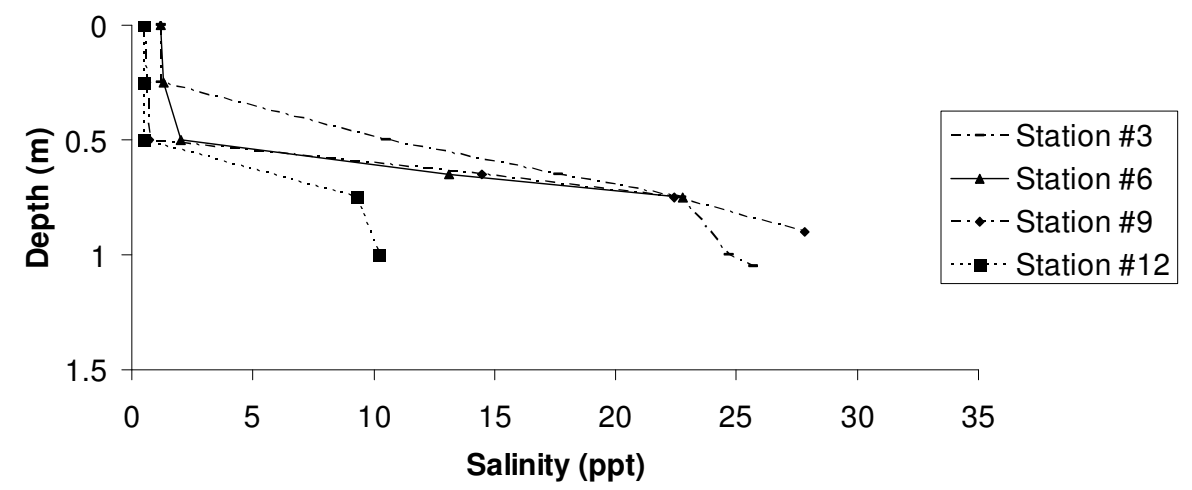

c)

September 09, 2005

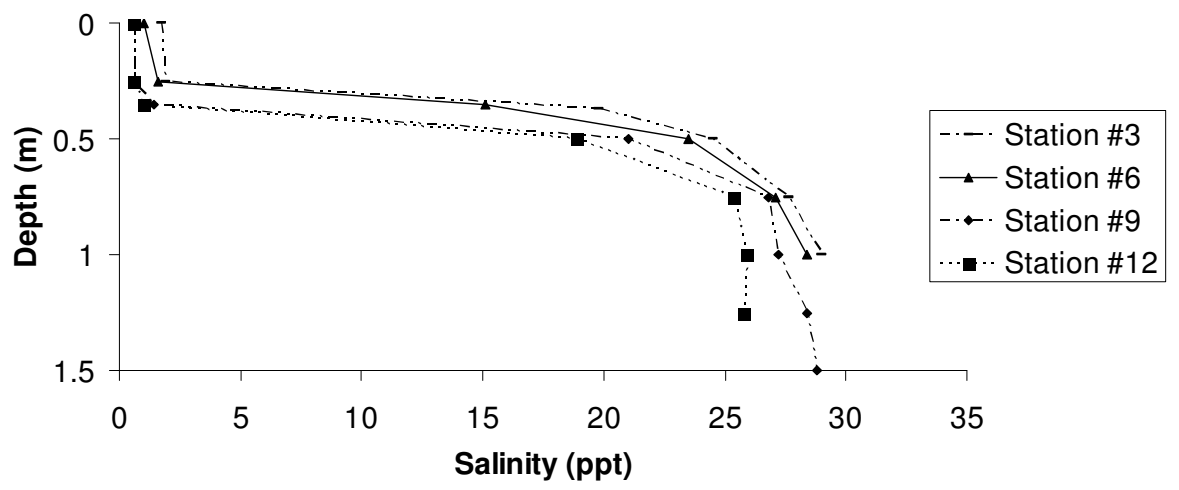

Figure 8. Salinity (ppt) at Stations \#3, 6, 9, and 12 on (a) August 04, (b) August 12, and (c) September 09, 2005 in San Gregorio Creek lagoon, San Mateo County. 
a)

\section{September 24, 2005}

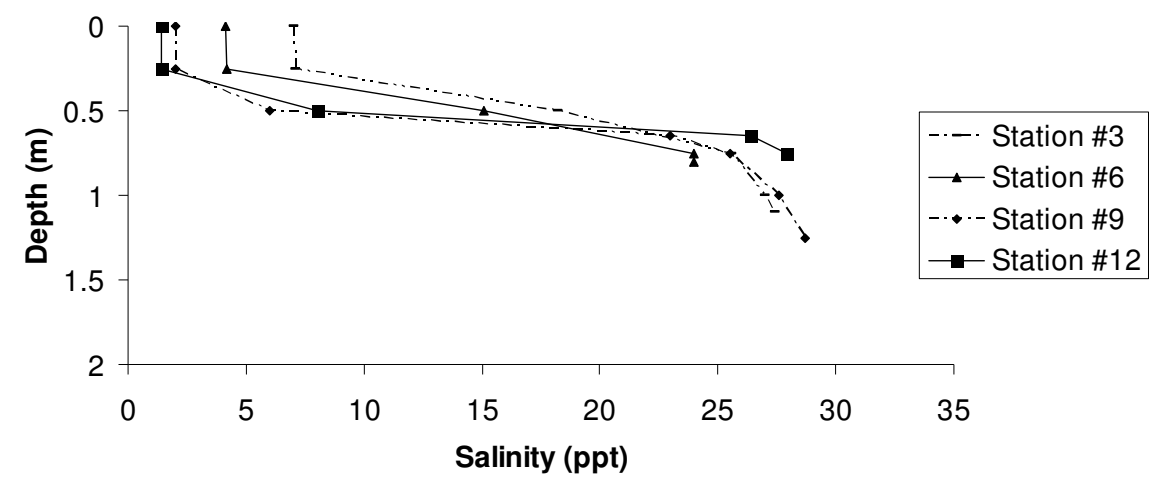

b)

October 14, 2005

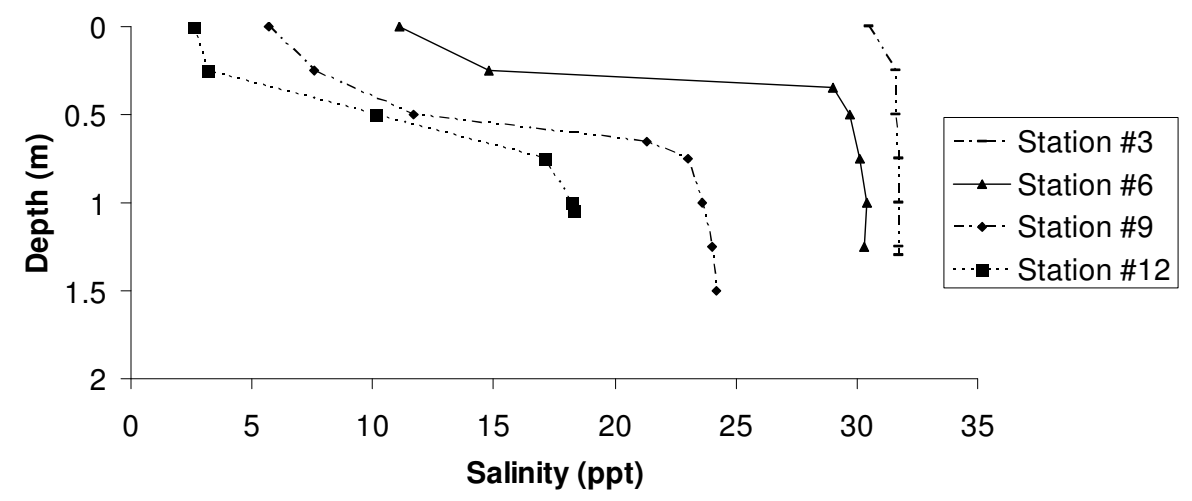

c)

October 29, 2005

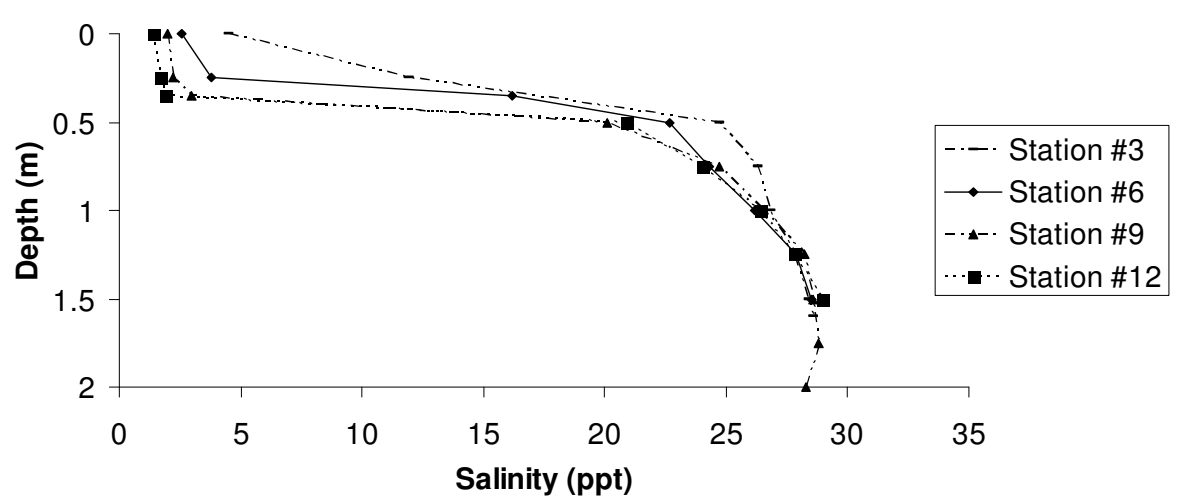

Figure 9. Salinity (ppt) at Stations \#3, 6, 9, and 12 on (a) September 24, (b) October 14, and (c) October 29, 2005 in San Gregorio Creek lagoon, San Mateo County. 
a)

November 18, 2005

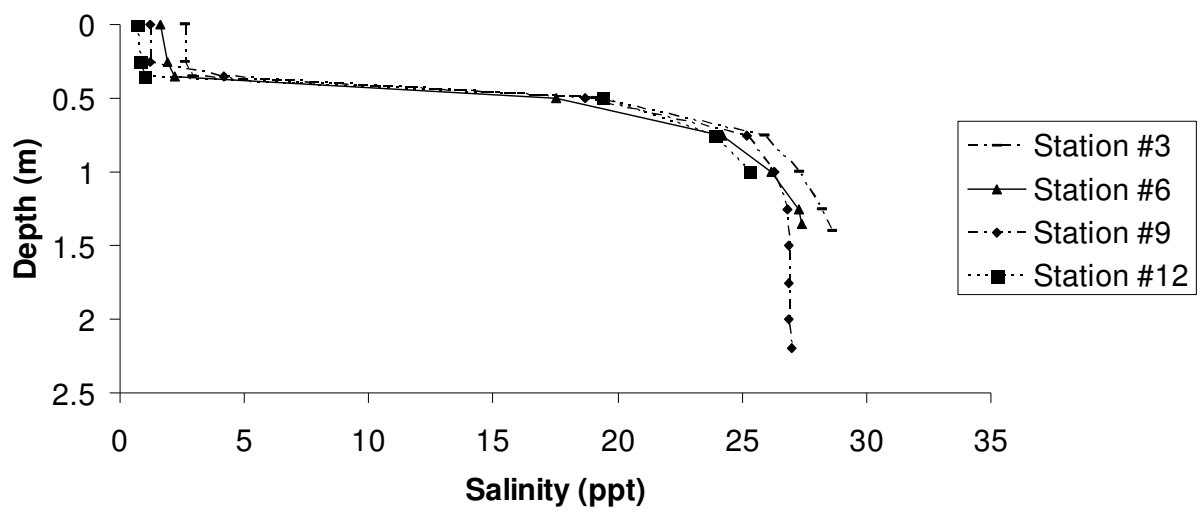

b)

December 02, 2005

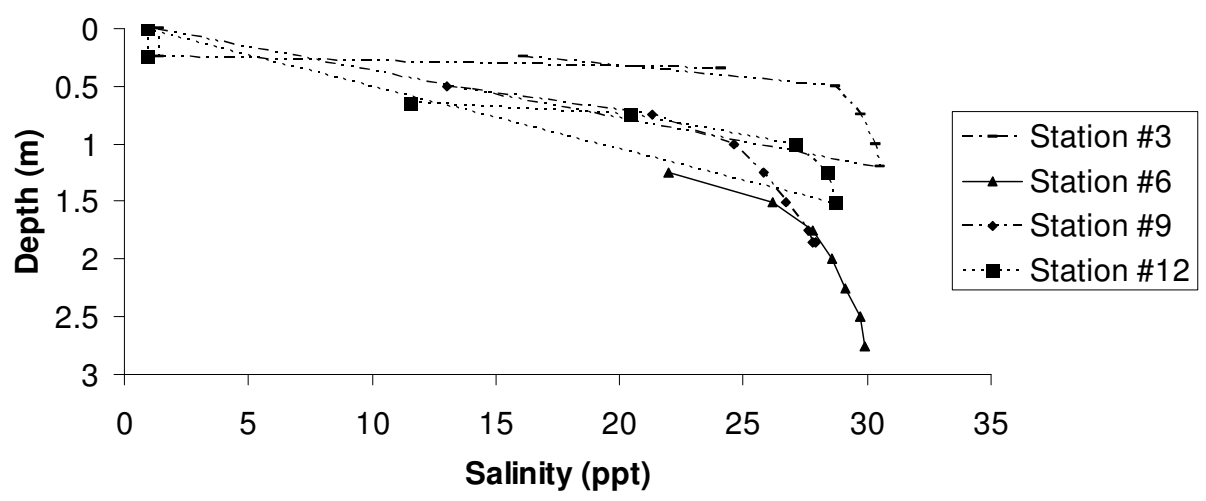

Figure 10. Salinity (ppt) at Stations \#3, 6, 9, and 12 on (a) November 18 and (b) December 02, 2005 in San Gregorio Creek lagoon, San Mateo County. 
a)

February 16, 2006

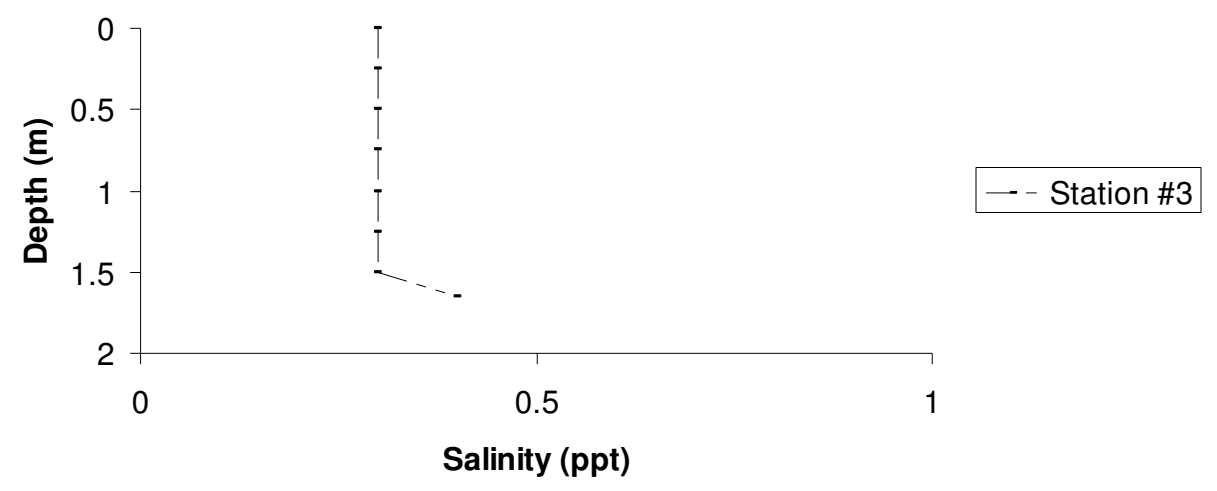

b)

March 16, 2006

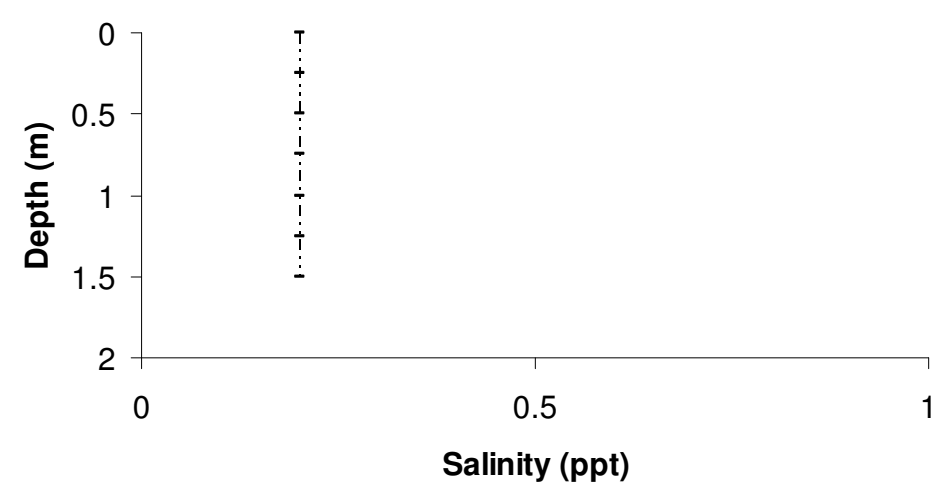

c)

May 19, 2006

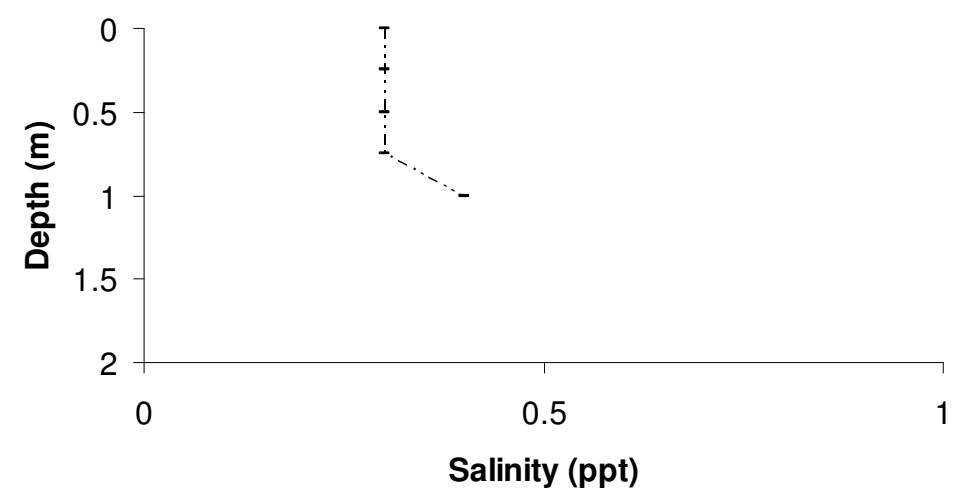

Figure 11. Salinity (ppt) at Station \#3 on (a) February 16, (b) March 16, and (c) May 19, 2006 in San Gregorio Creek lagoon, San Mateo County. 
a)

June 16, 2006

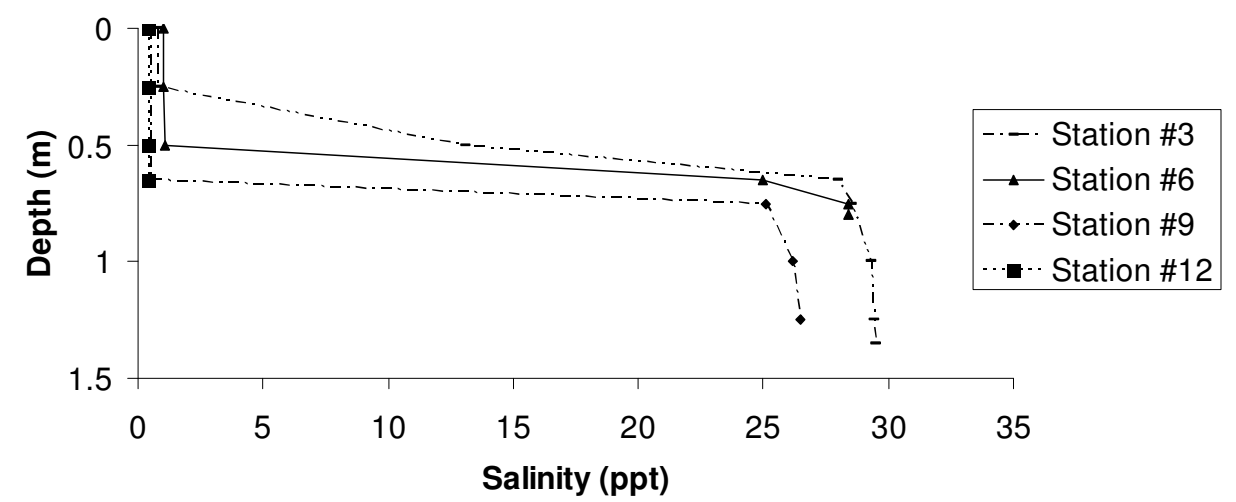

b)

July 14, 2006

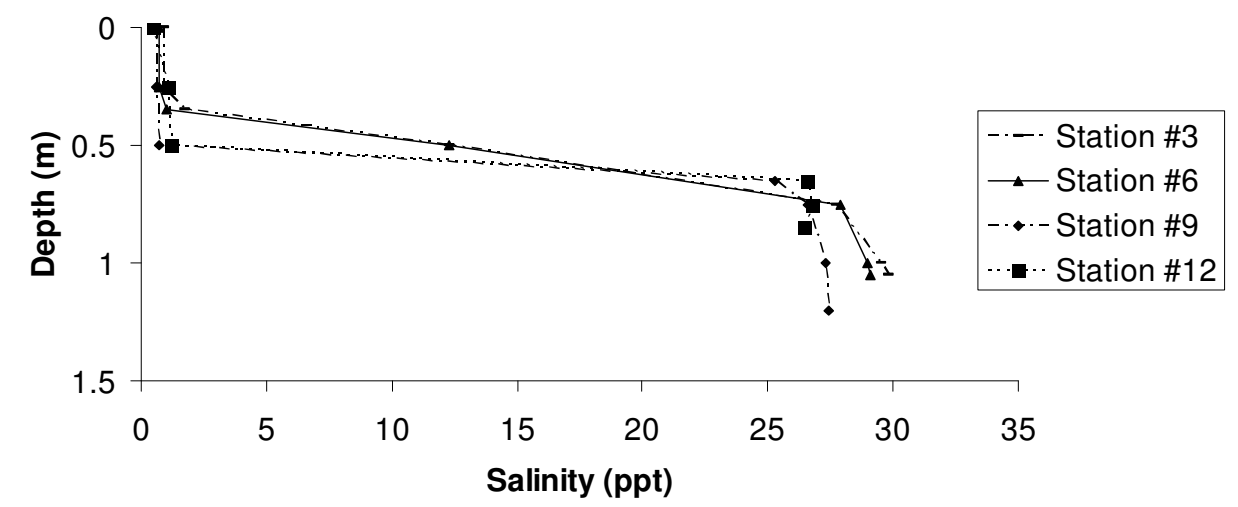

c)

\section{August 11, 2006}

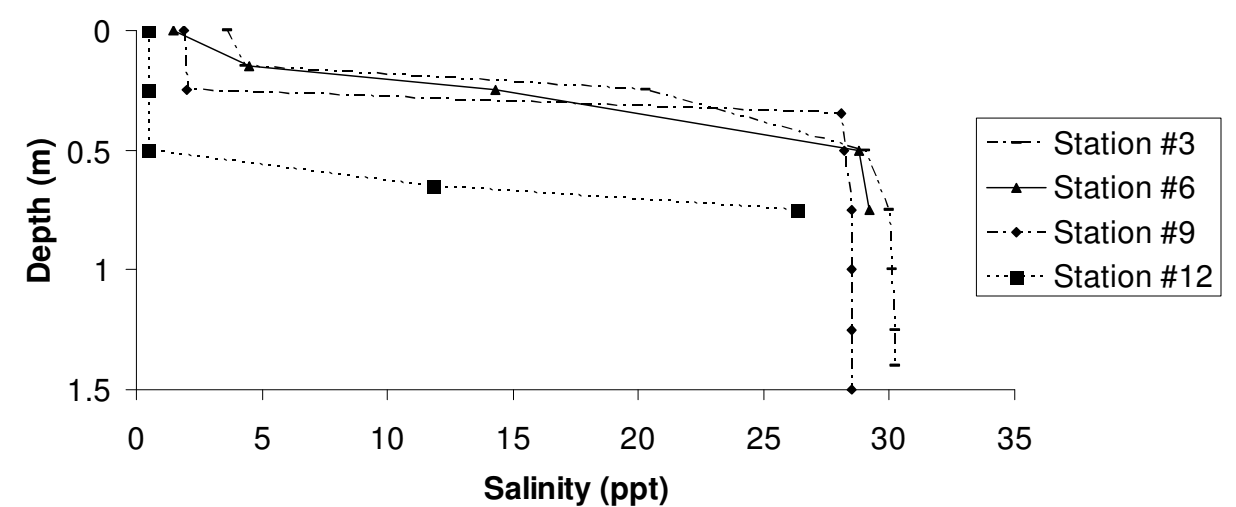

Figure 12. Salinity (ppt) at Stations \#3, 6, 9, and 12 on (a) June 16, (b) July 14, and (c) August 11, 2006 in San Gregorio Creek lagoon, San Mateo County. 
a)

August 18, 2006

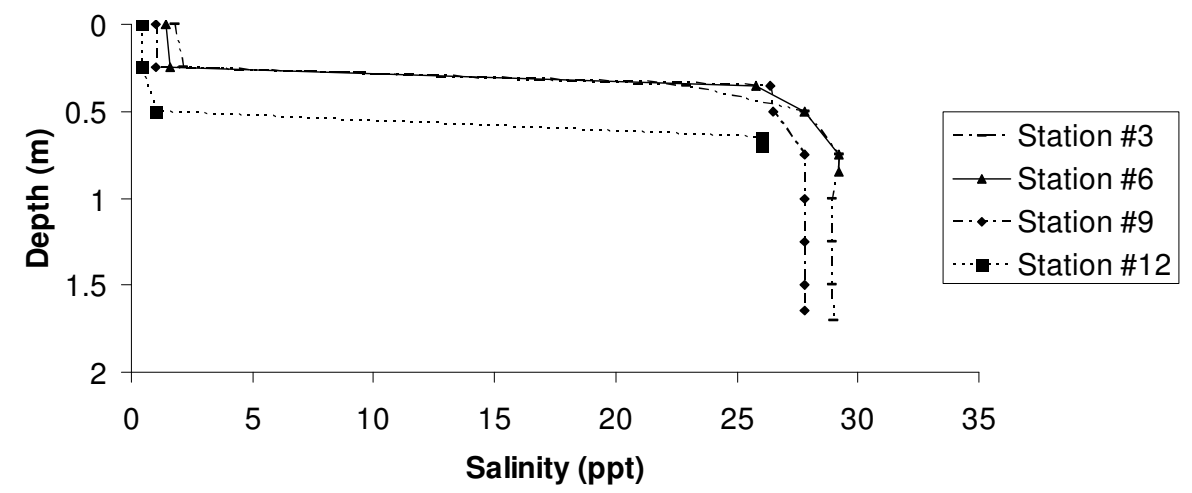

b)

September 08, 2006

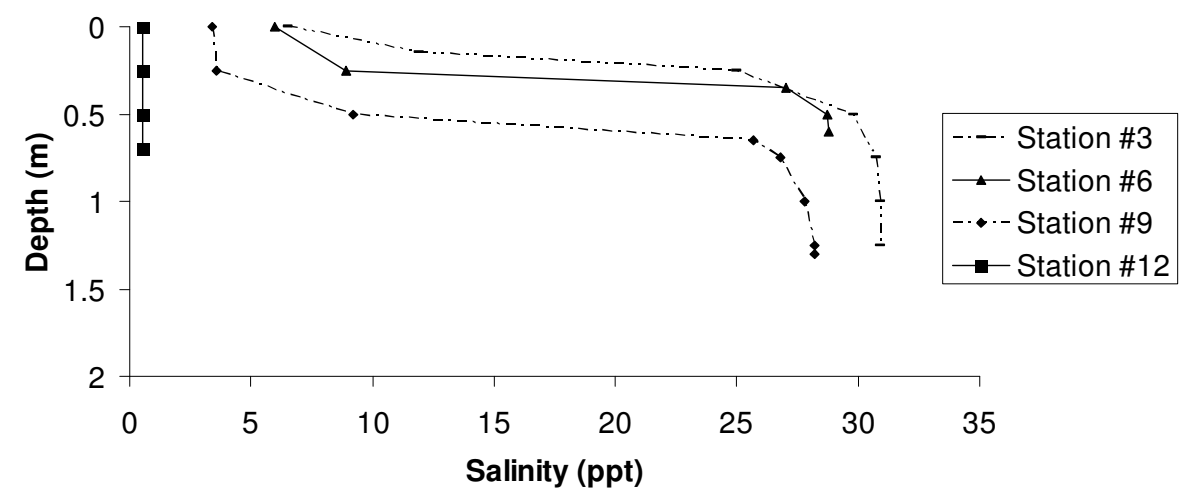

c)

September 15, 2006

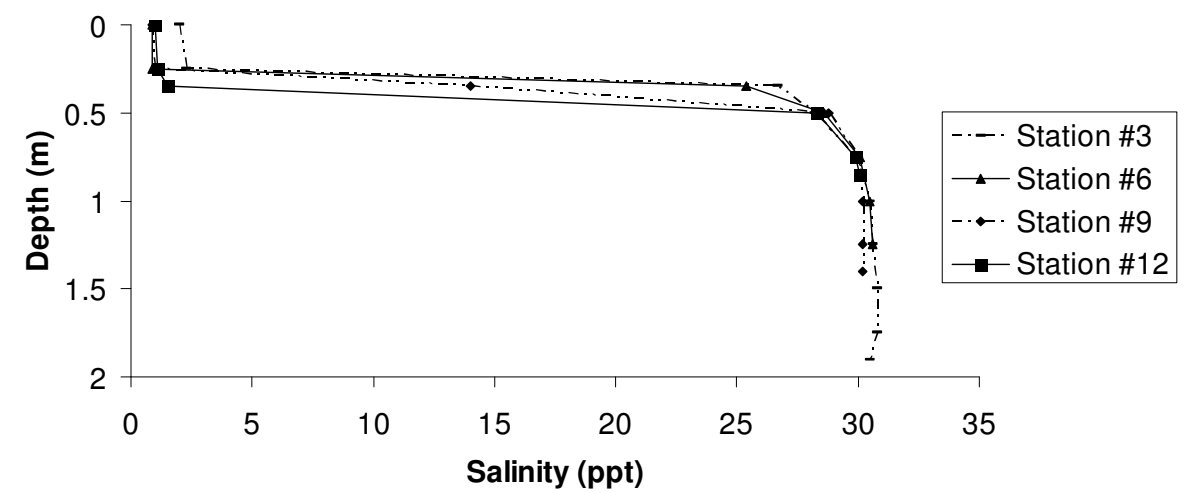

Figure 13. Salinity (ppt) at Stations \#3, 6, 9, and 12 on (a) August 18, (b) September 08, and (c) September 15, 2006 in San Gregorio Creek lagoon, San Mateo County. 
a)

October 05, 2006

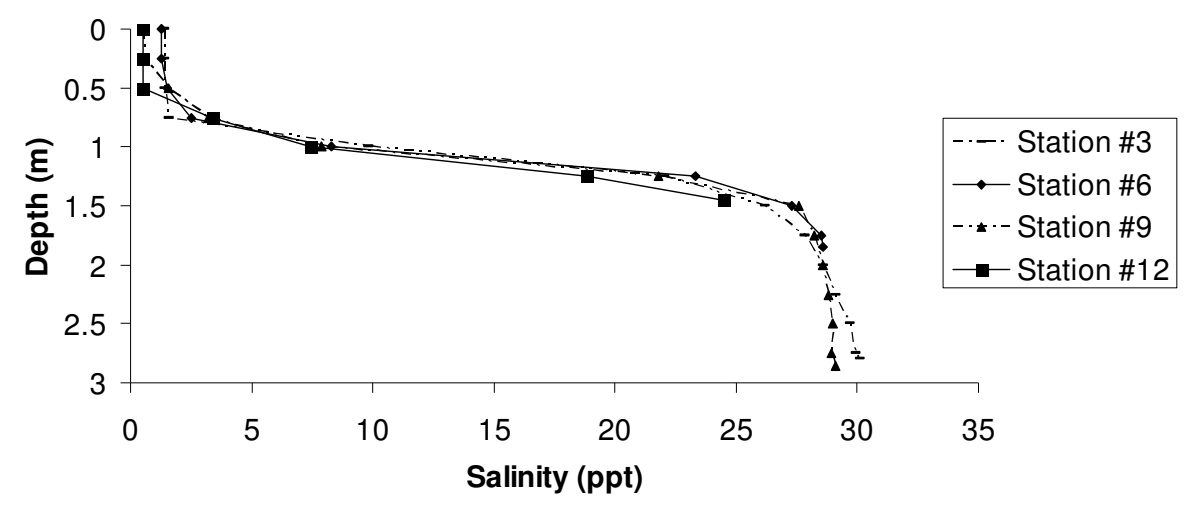

b)

November 02, 2006

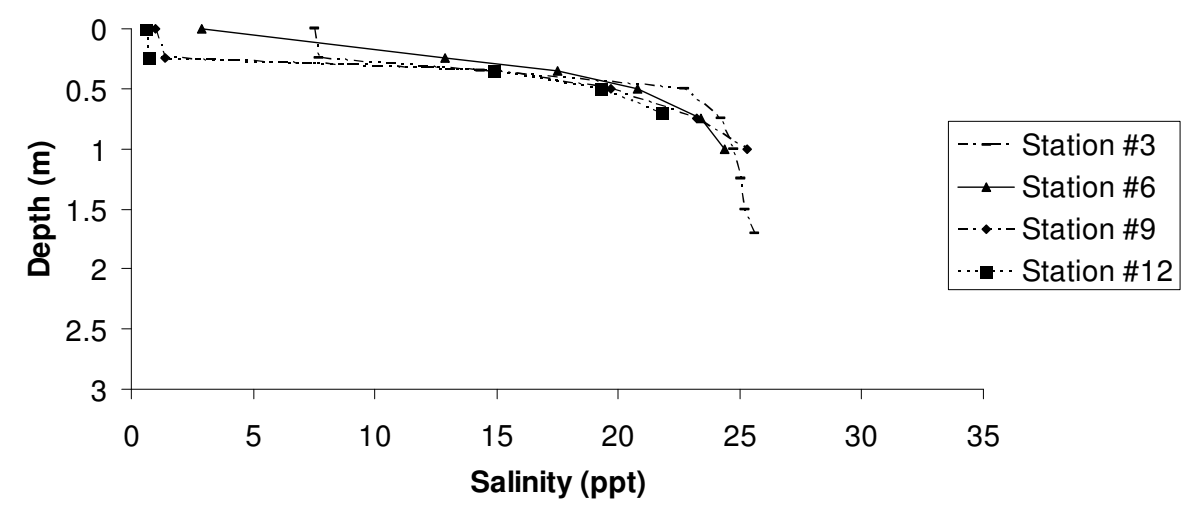

c)

November 30, 2006

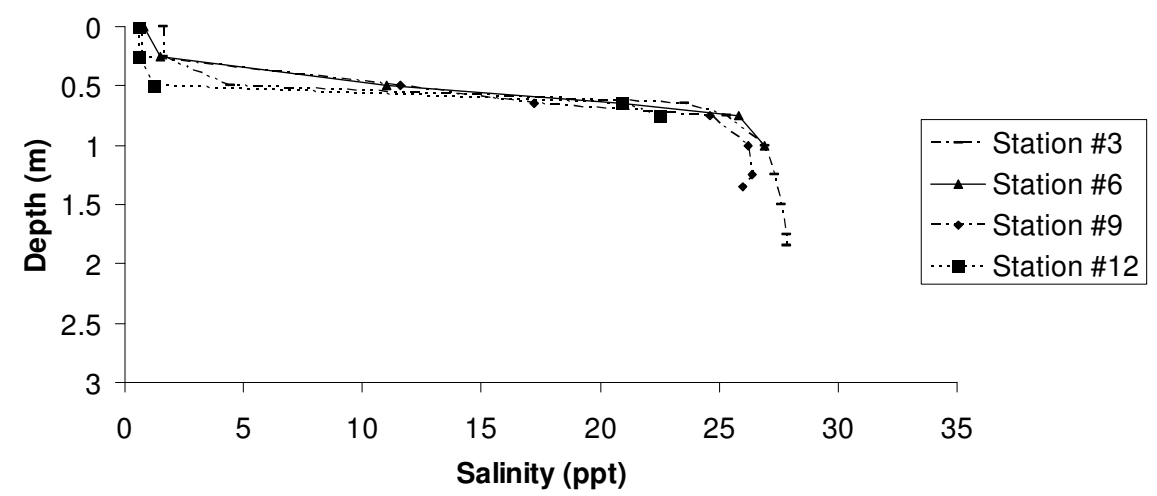

Figure 14. Salinity (ppt) at Stations \#3, 6, 9, and 12 on (a) October 05, (b) November 02, and (c) November 30, 2006 in San Gregorio Creek lagoon, San Mateo County. 
April 18, 2008

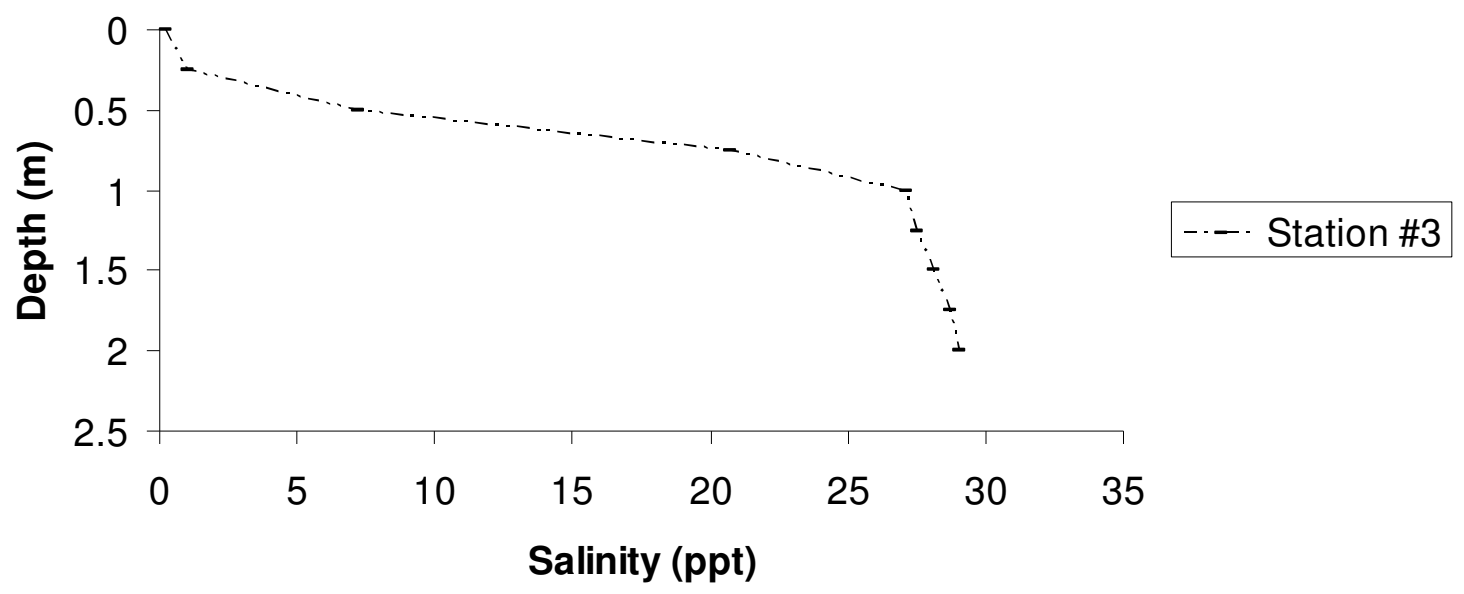

Figure 15. Salinity (ppt) at Station \#3 April 18, 2008 in San Gregorio Creek lagoon, San Mateo County. 
a)

June 17, 2005

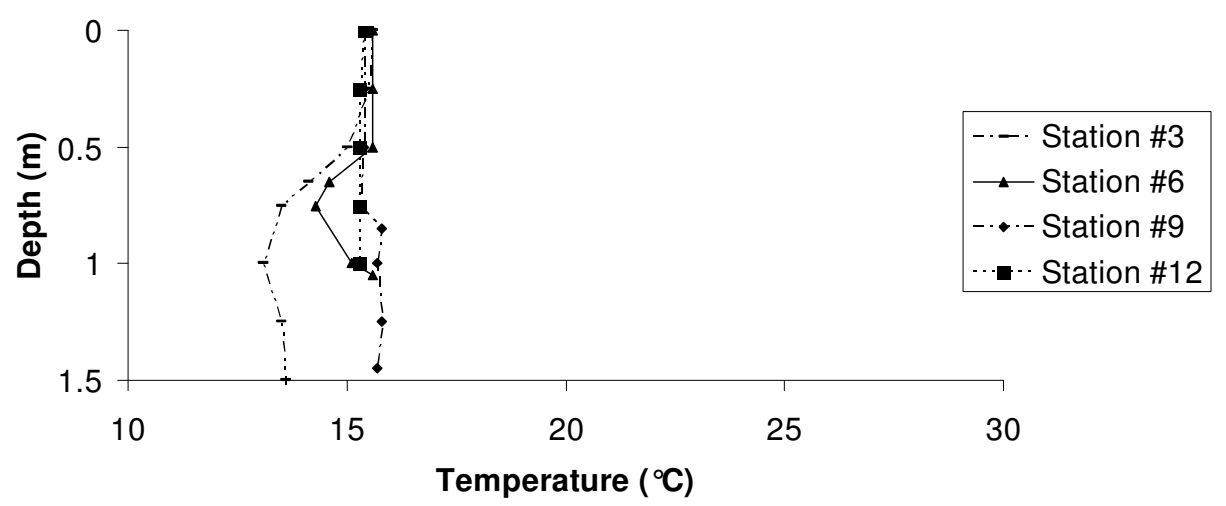

b)

July 15, 2005

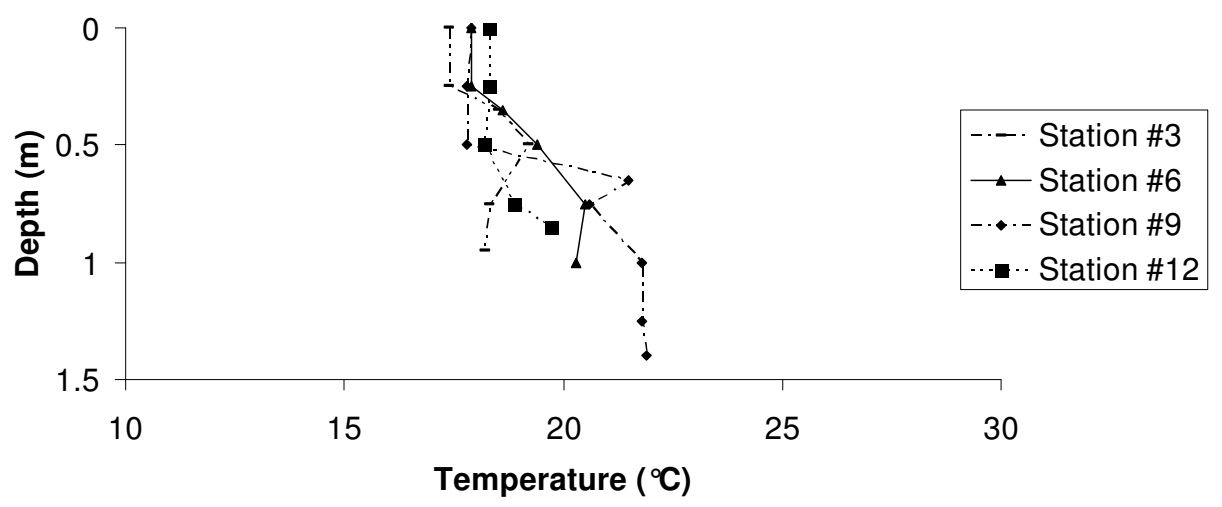

Figure 16. Temperature $\left({ }^{\circ} \mathrm{C}\right)$ at Stations \#3, 6, 9, and 12 on (a) June 17 and (b) July 15, 2005 in San Gregorio Creek lagoon, San Mateo County. 
a)

\section{August 04, 2005}

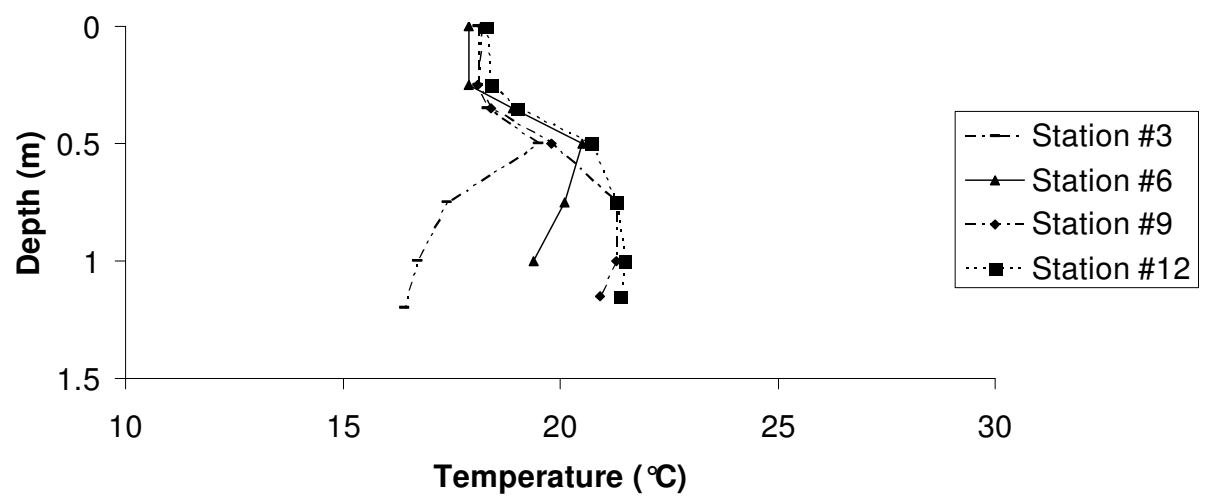

b)

August 12, 2005

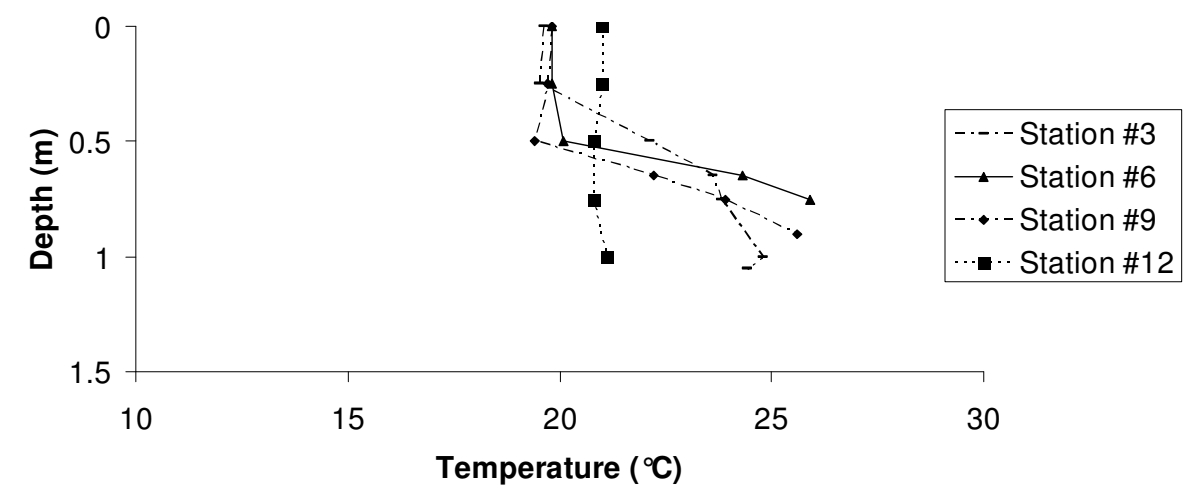

c)

September 09, 2005

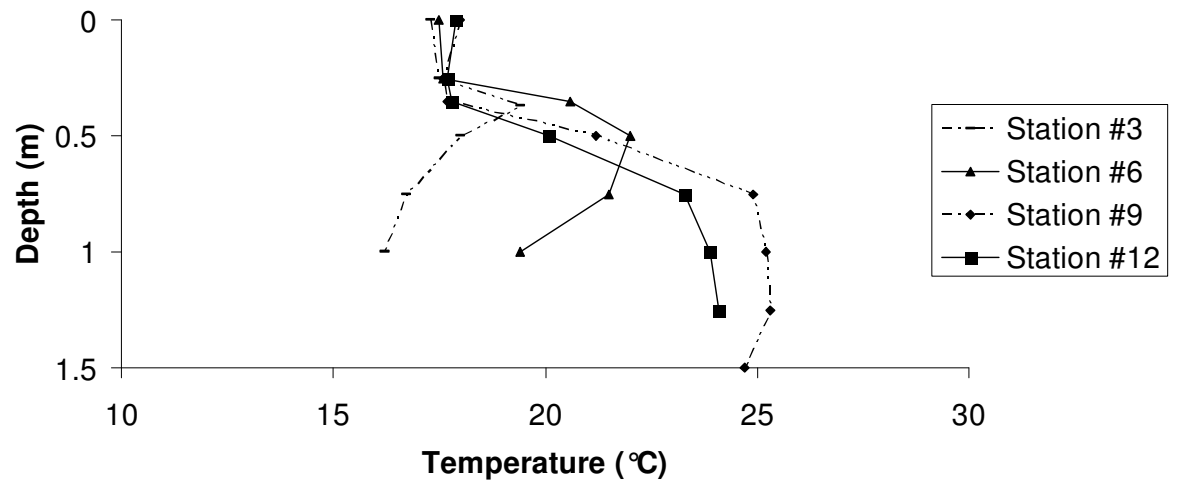

Figure 17. Temperature $\left({ }^{\circ} \mathrm{C}\right)$ at Stations \#3, 6, 9, and 12 on (a) August 04, (b) August 12, and (c) September 09, 2005 in San Gregorio Creek lagoon, San Mateo County. 
a)

September 24, 2005

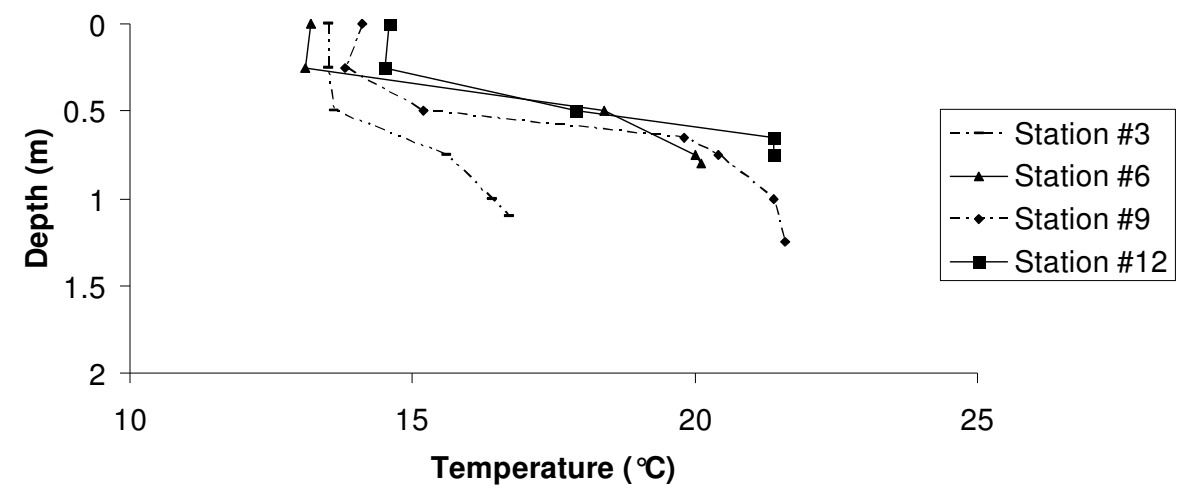

b)

October 14, 2005

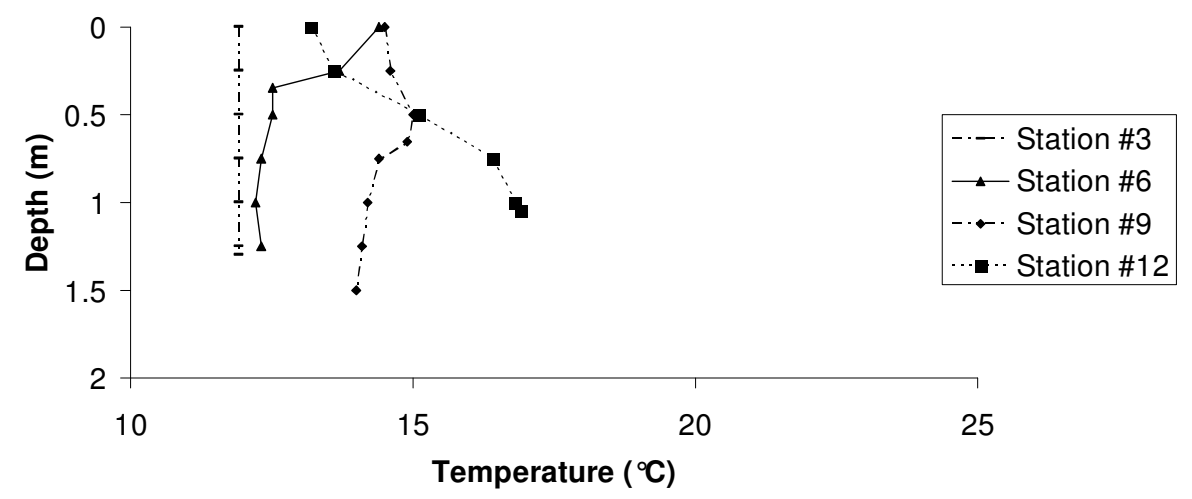

c)

October 29, 2005

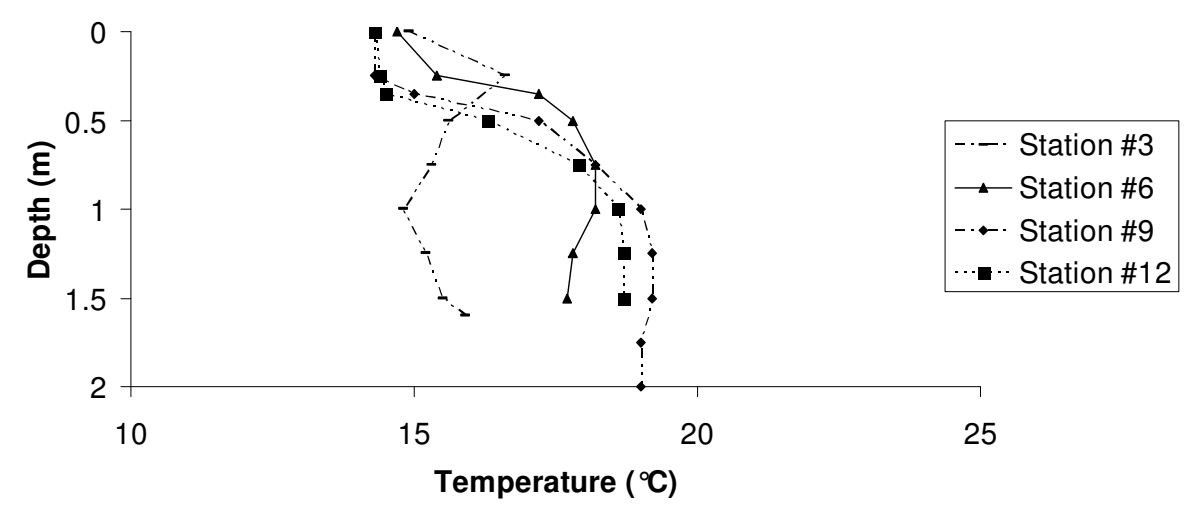

Figure 18. Temperature $\left({ }^{\circ} \mathrm{C}\right)$ at Stations \#3, 6, 9, and 12 on (a) September 24, (b) October 14, and (c) October 29, 2005 in San Gregorio Creek lagoon, San Mateo County. 
a)

November 18, 2005

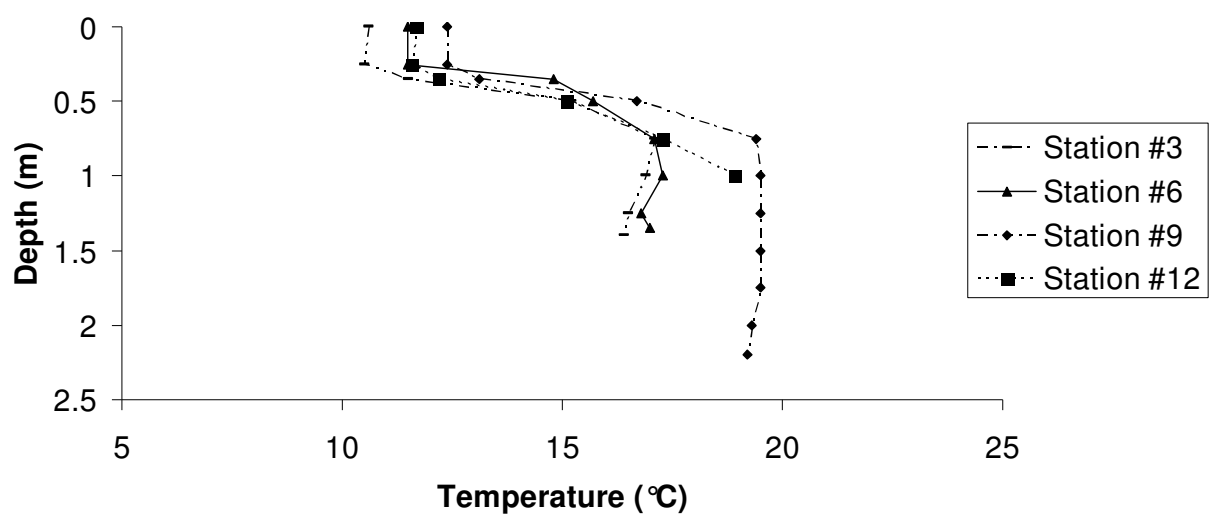

b)

December 02, 2005

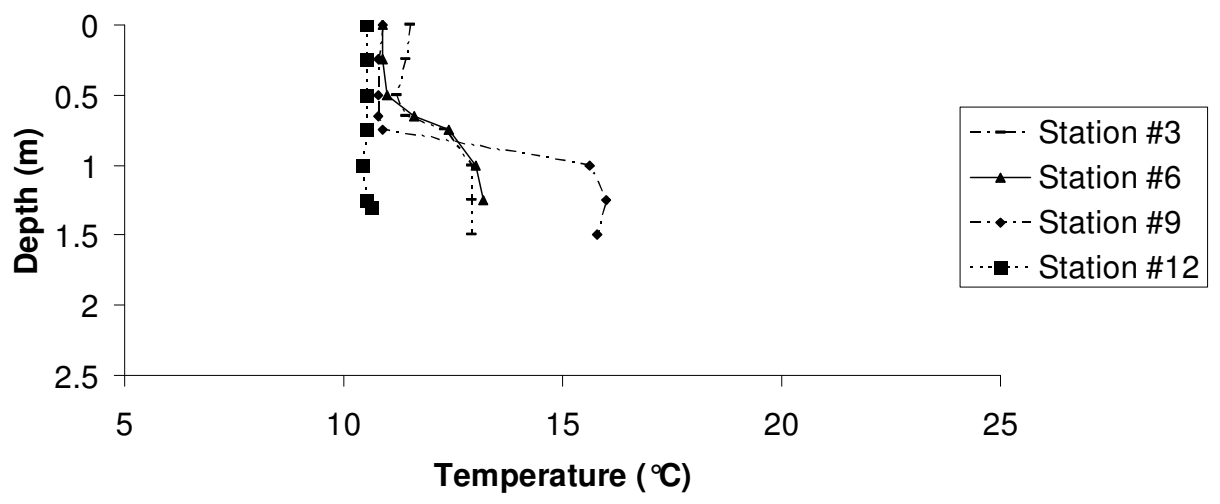

Figure 19. Temperature $\left({ }^{\circ} \mathrm{C}\right)$ at Stations \#3, 6, 9, and 12 on (a) November 18 and (b) December 02, 2005 in San Gregorio Creek lagoon, San Mateo County. 
a)

February 16, 2006

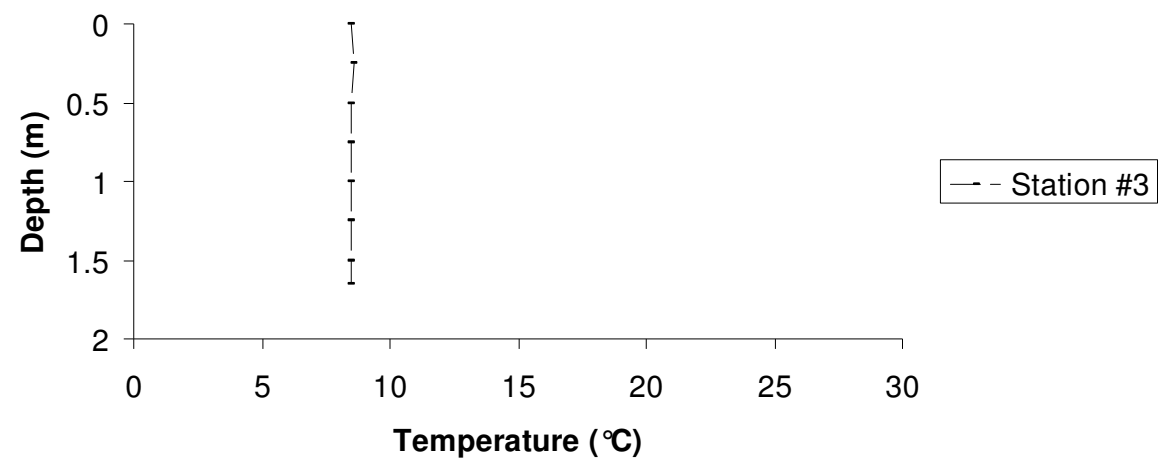

b)

March 16, 2006

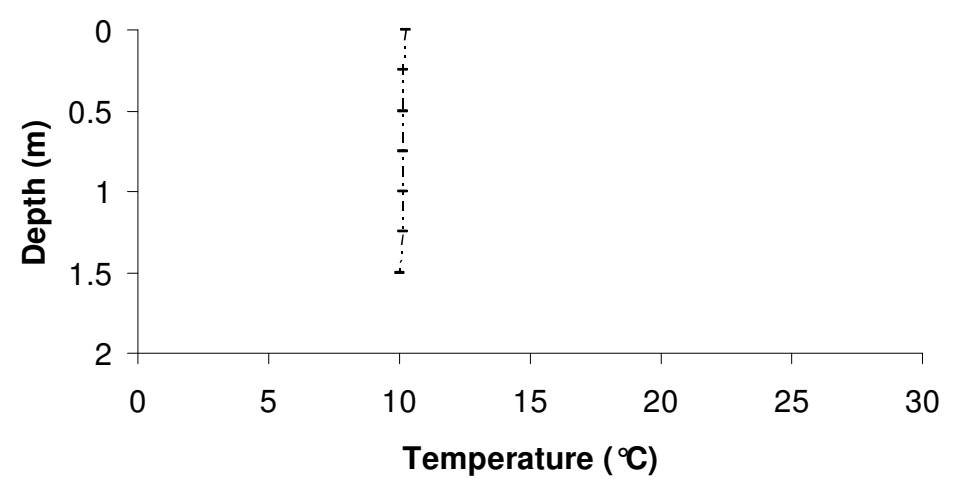

c)

\section{May 19, 2006}

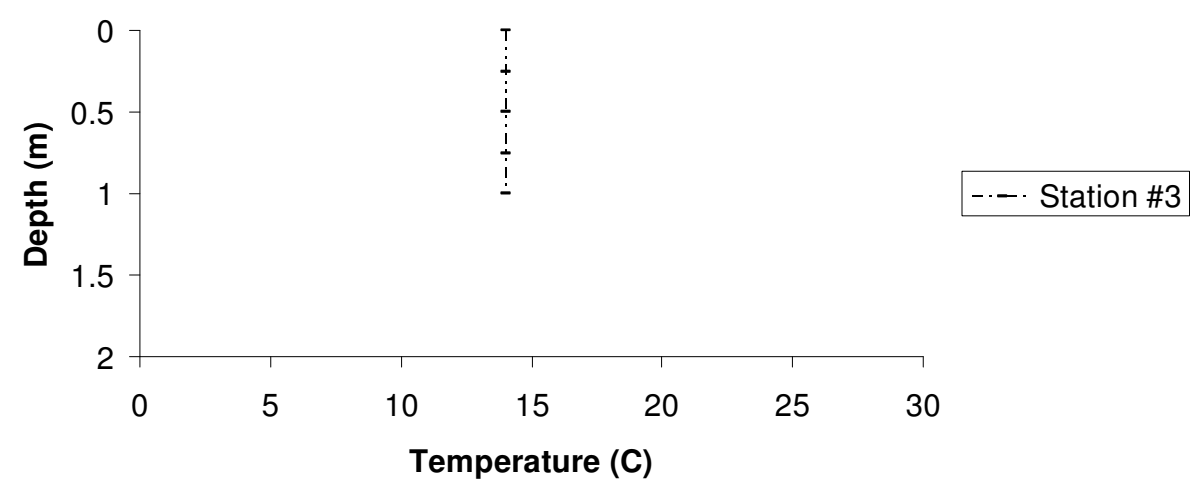

Figure 20. Temperature $\left({ }^{\circ} \mathrm{C}\right)$ at Station \#3 on (a) February 16, (b) March 16, and (c) May 19, 2006 in San Gregorio Creek lagoon, San Mateo County. 
a)

June 17, 2005

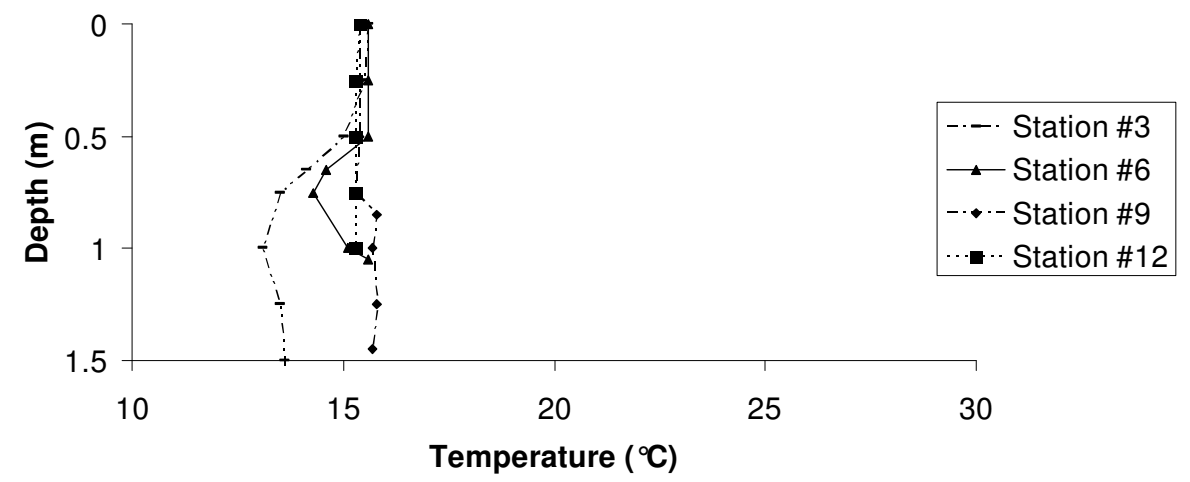

b)

July 14, 2006

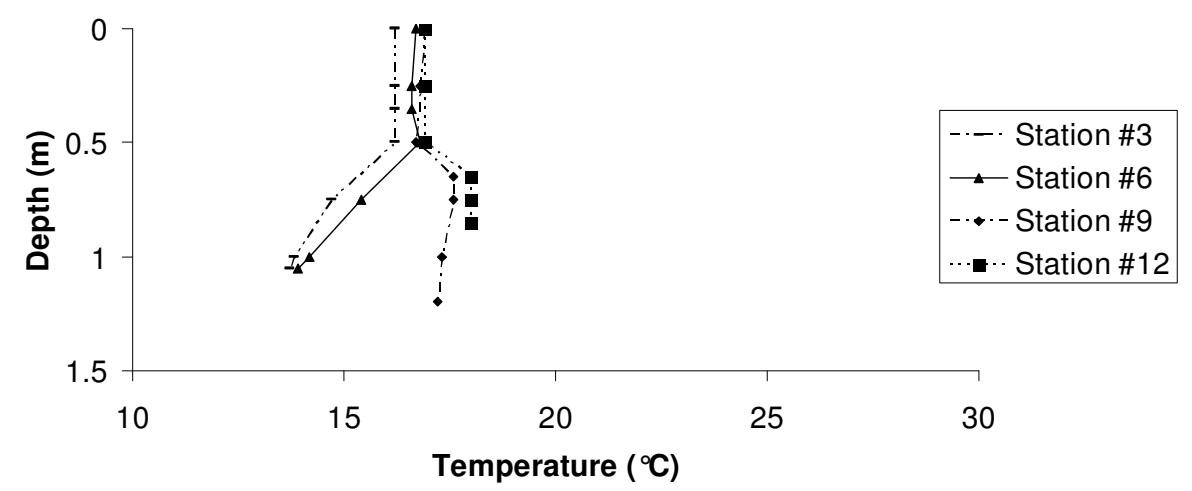

c)

August 11, 2006

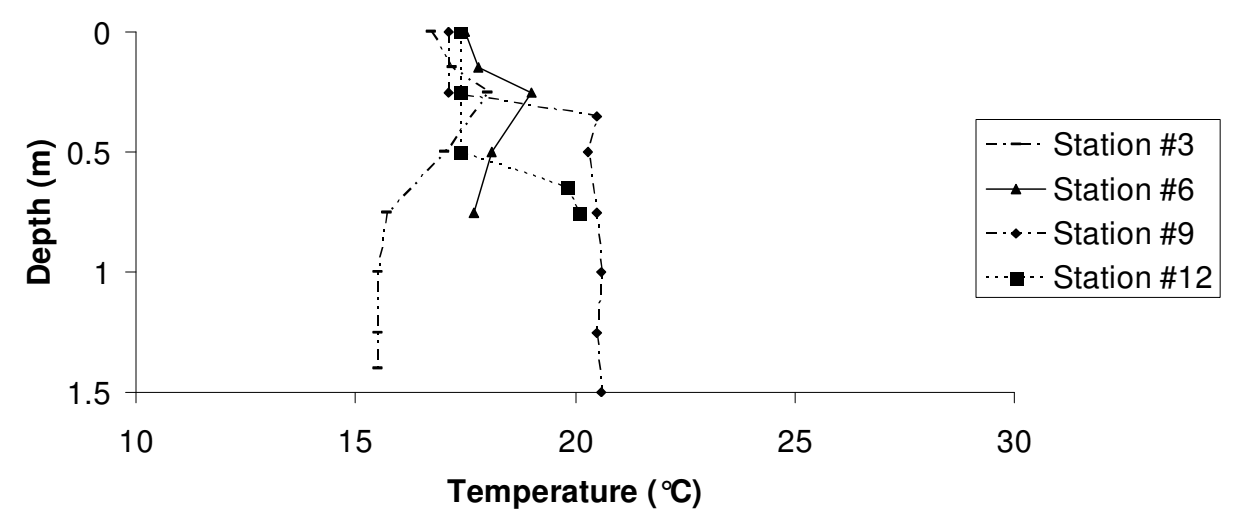

Figure 21. Temperature $\left({ }^{\circ} \mathrm{C}\right)$ at Stations \#3, 6, 9, and 12 on (a) June 17, (b) July 14, and (c) August 11, 2006 in San Gregorio Creek lagoon, San Mateo County. 
a)

August 18, 2006

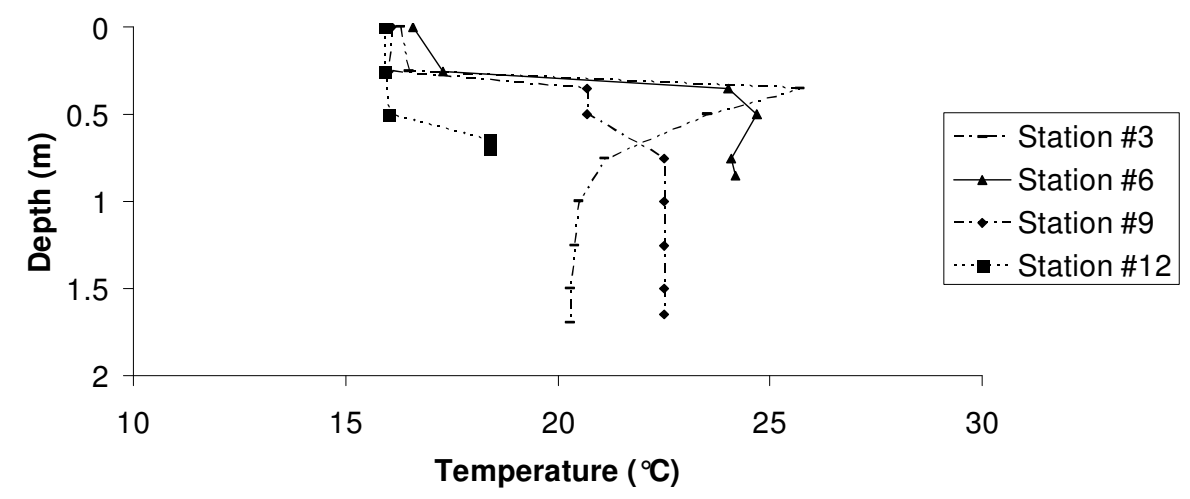

b)

September 08, 2006

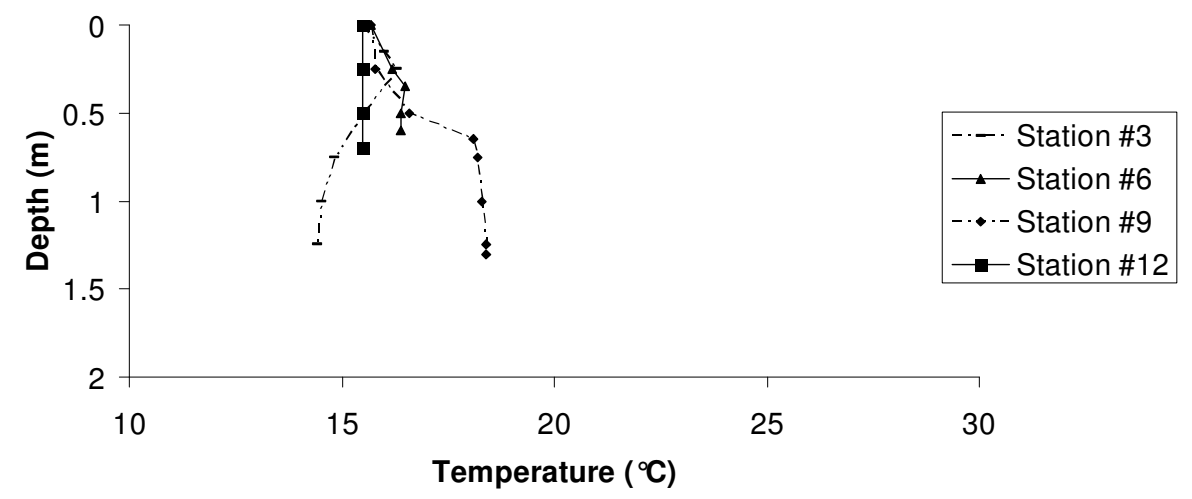

c)

September 15, 2006

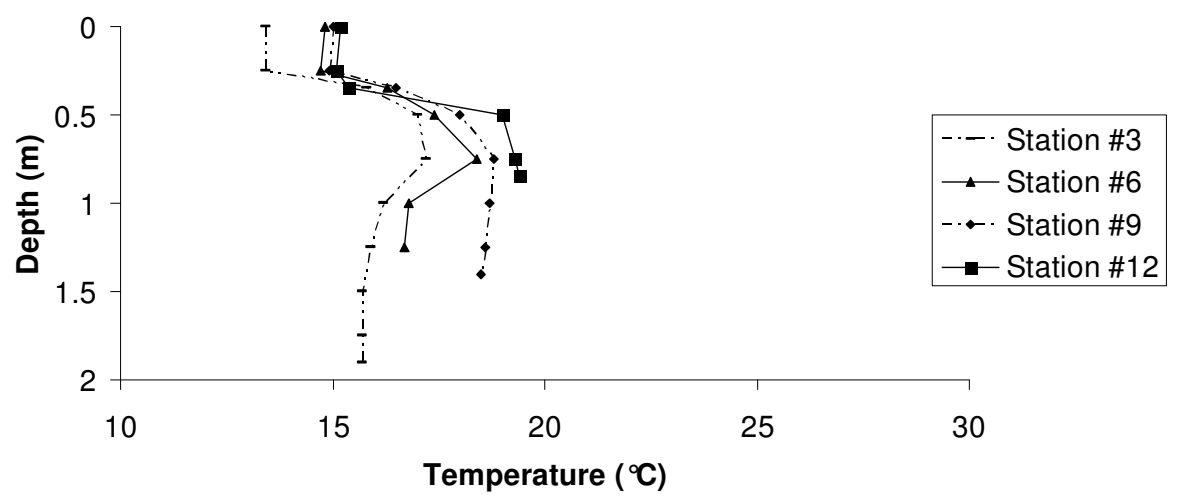

Figure 22. Temperature $\left({ }^{\circ} \mathrm{C}\right)$ at Stations \#3, 6, 9, and 12 on (a) August 18, (b) September 08, and (c) September 15, 2006 in San Gregorio Creek lagoon, San Mateo County. 
a)

October 05, 2006

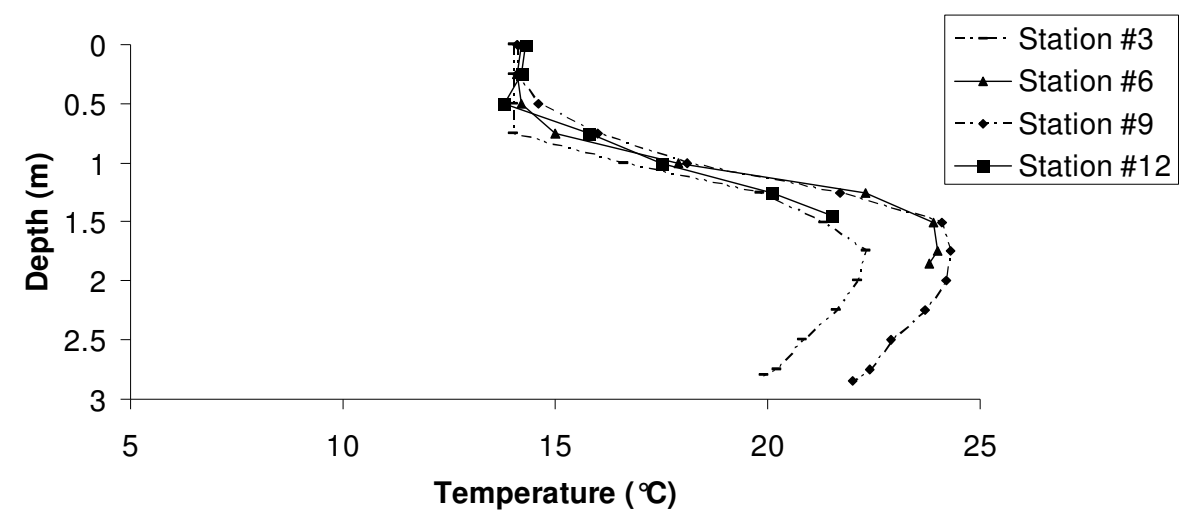

b)

November 02, 2006

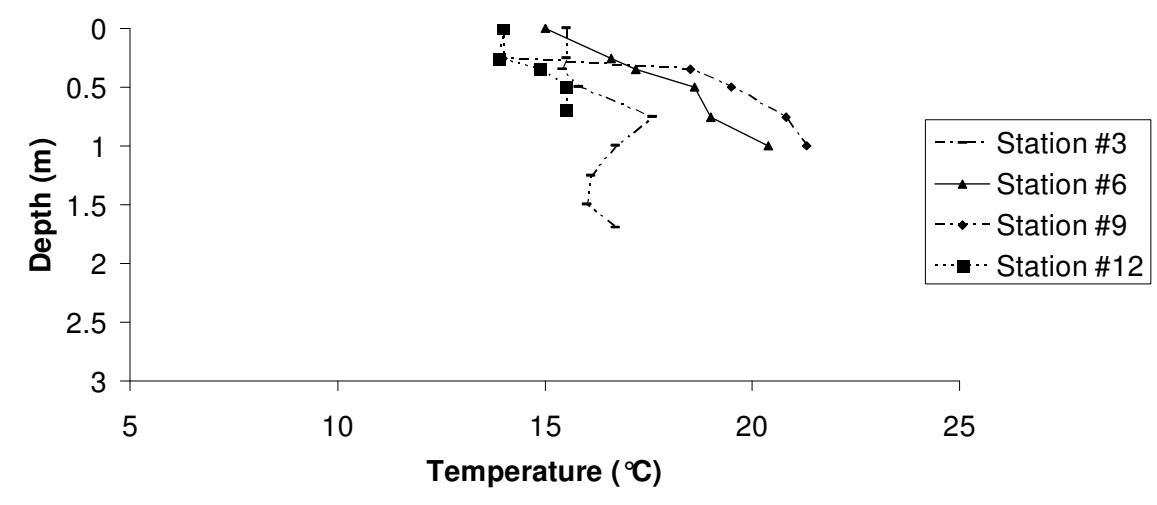

c)

November 30, 2006

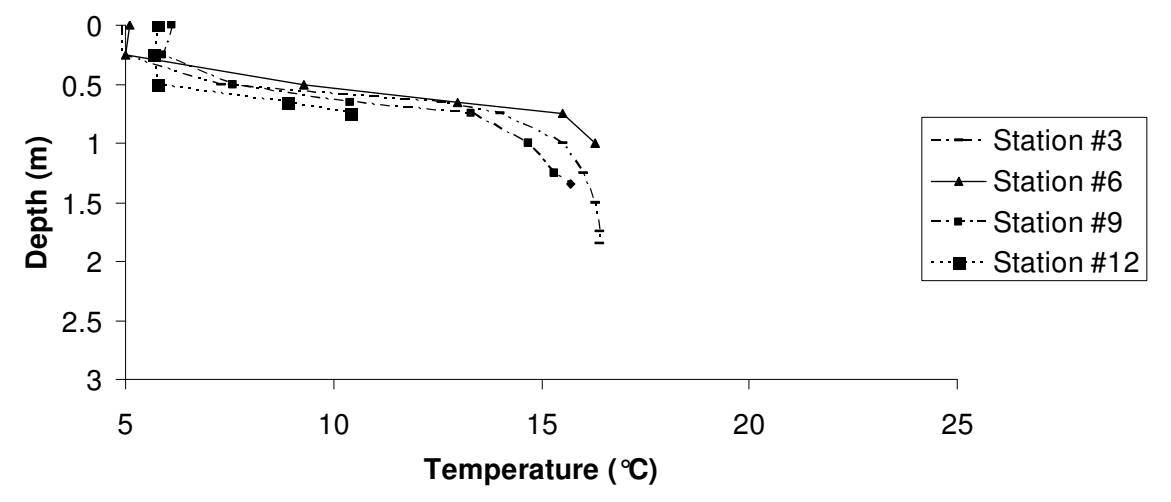

Figure 23. Temperature $\left({ }^{\circ} \mathrm{C}\right)$ at Stations \#3, 6, 9, and 12 on (a) October 05, (b) November 02, and (c) November 30, 2006 in San Gregorio Creek lagoon, San Mateo County. 


\section{April 18, 2008}

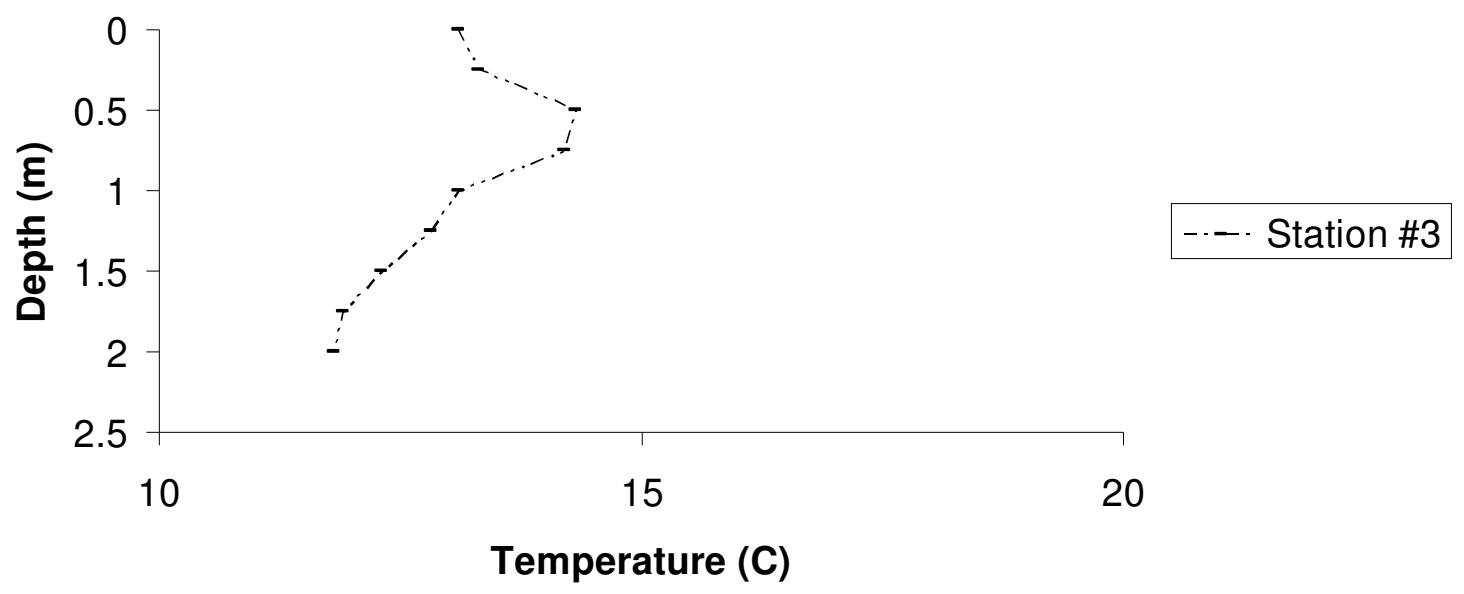

Figure 24. Temperature $\left({ }^{\circ} \mathrm{C}\right)$ at Station \#3 April 18, 2008 in San Gregorio Creek lagoon, San Mateo County. 
a)

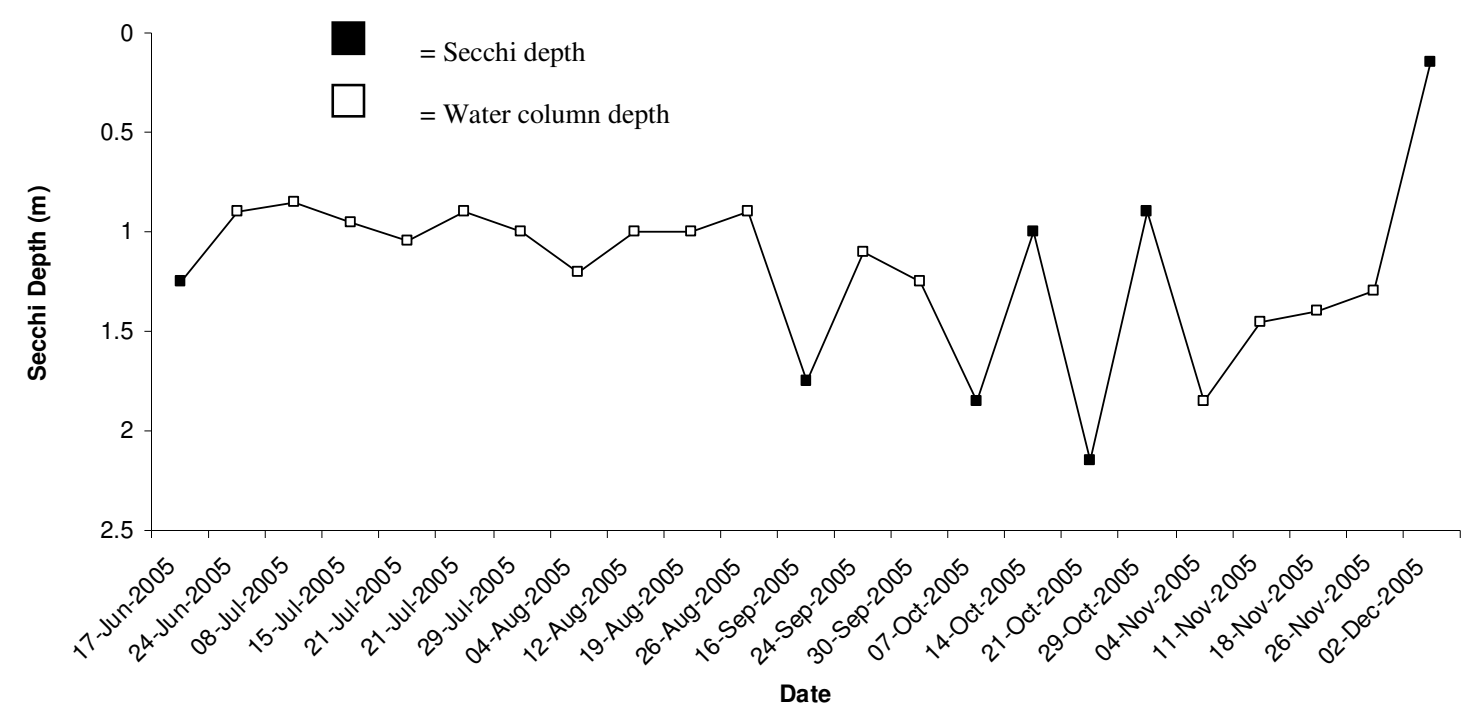

b)

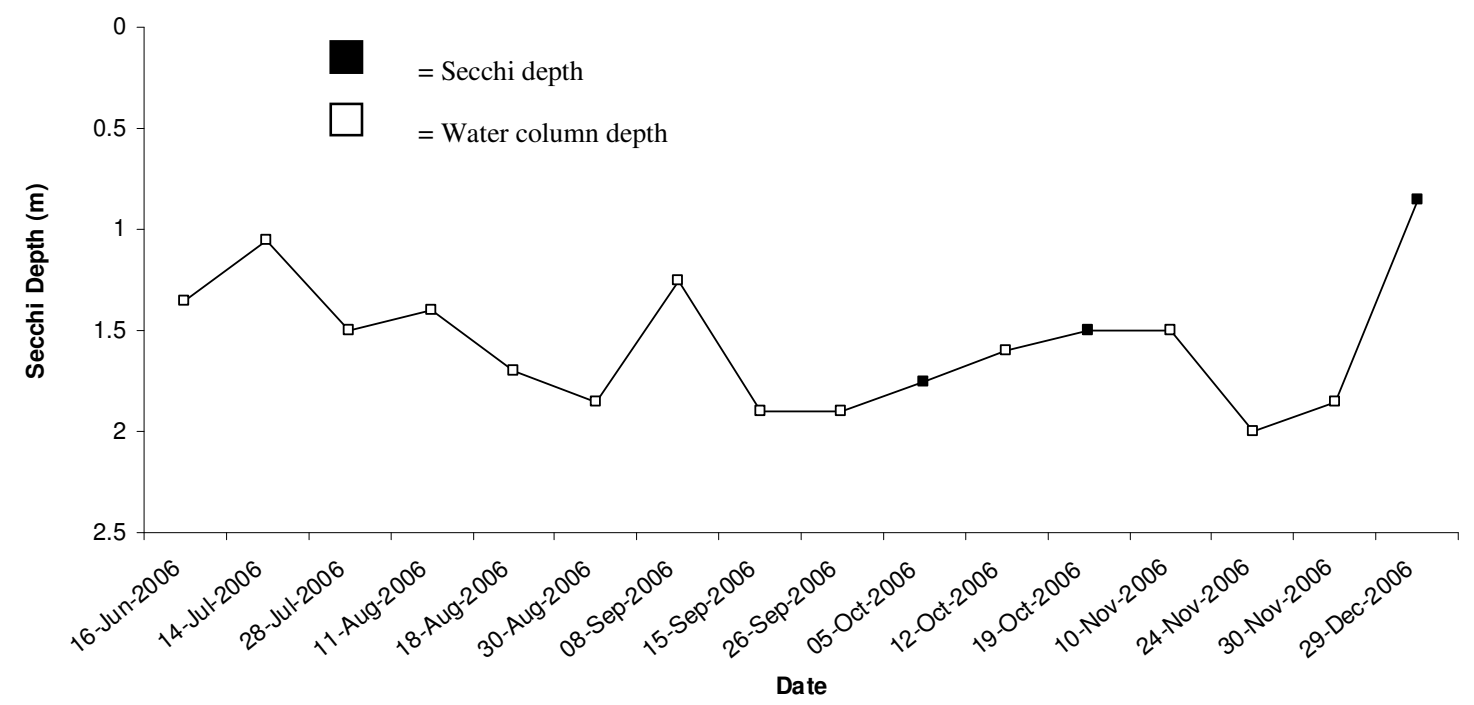

Figure 25 Mean values of secchi depth measurements at Station \#3 during the summer and fall of (a) 2005 and (b) 2006 at San Gregorio Creek lagoon, San Mateo County. Water column depth is plotted only where secchi depth was determined to be greater than water column depth. 
a)

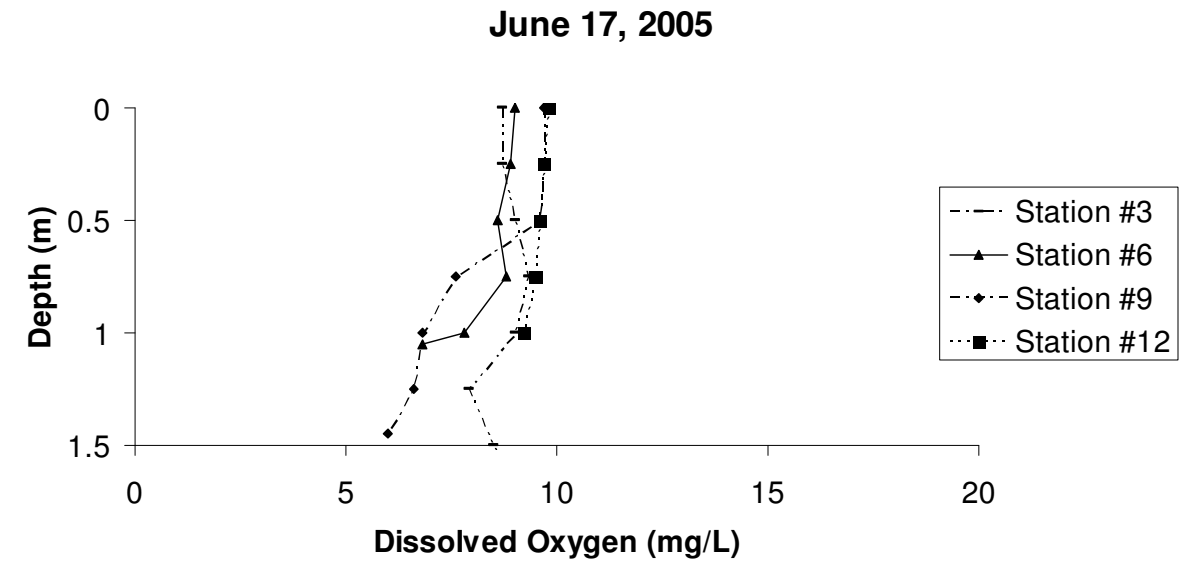

b)

July 15, 2005

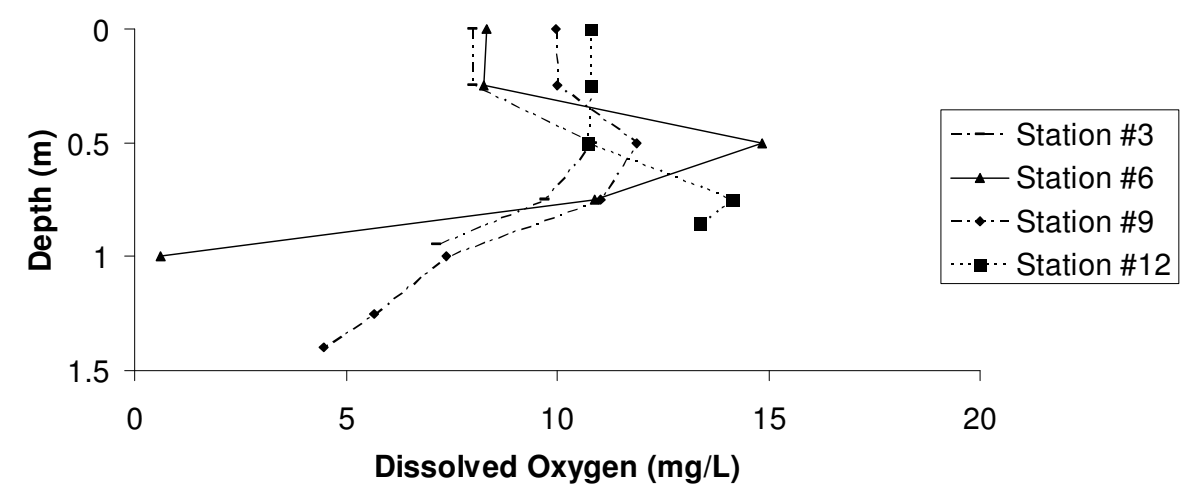

c)

July 29, 2005

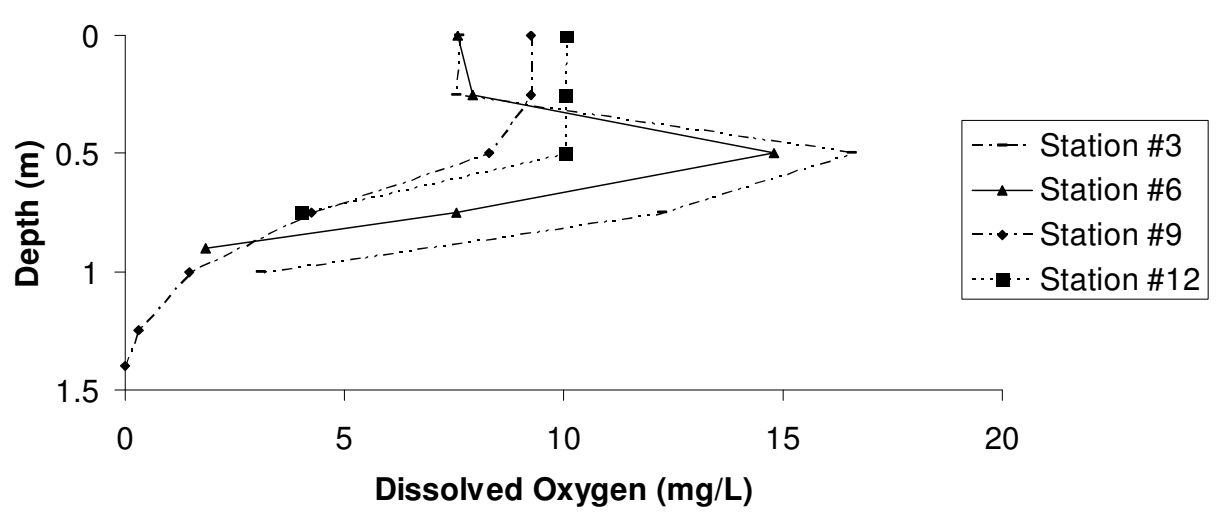

Figure 26. Dissolved oxygen (mg/L) at Stations \#3, 6, 9, and 12 on (a) June 17, (b) July 15, and (c) July 29, 2005 in San Gregorio Creek lagoon, San Mateo County. 
a)

August 04, 2005

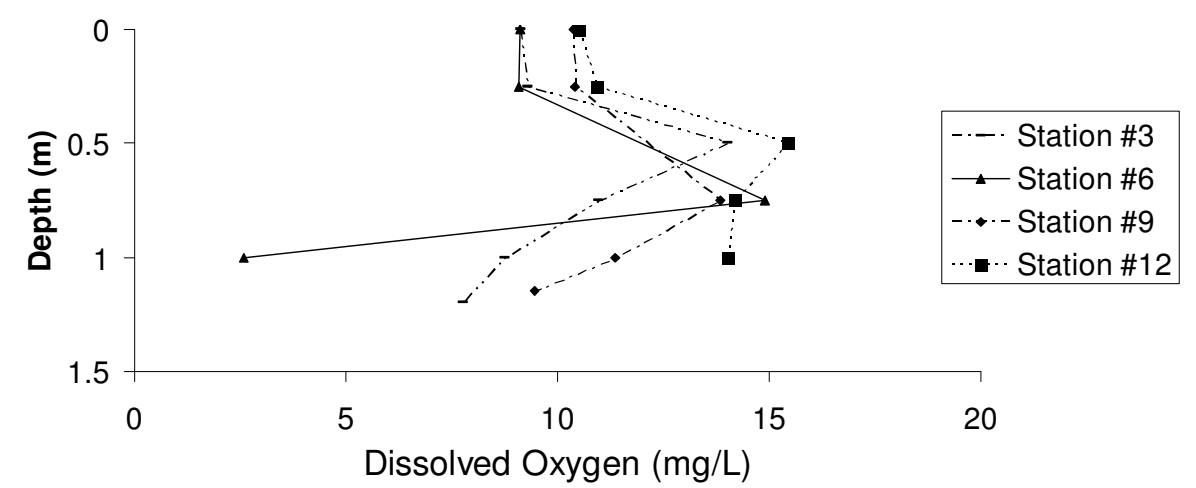

b)

August 12, 2005

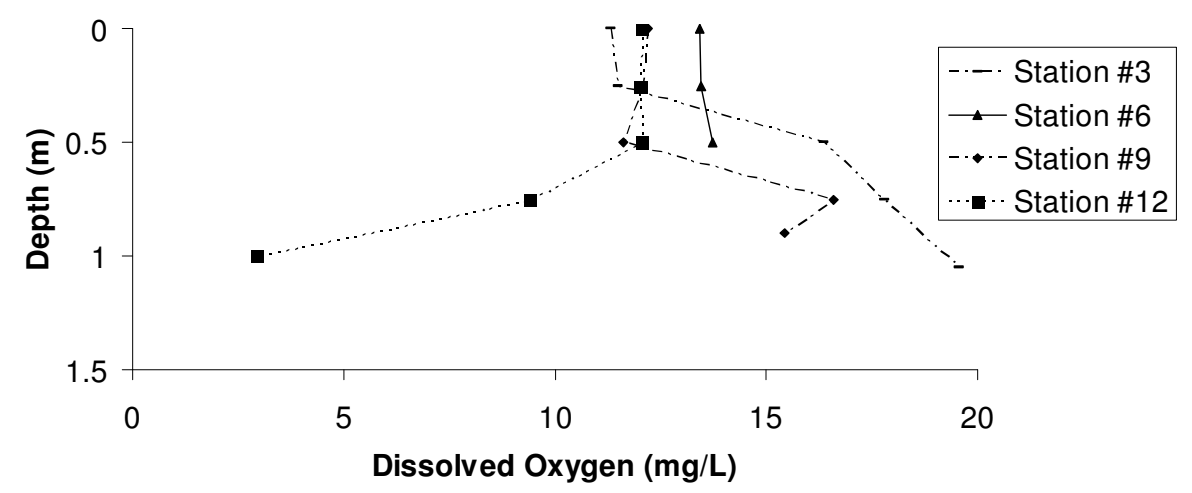

c)

September 09, 2005

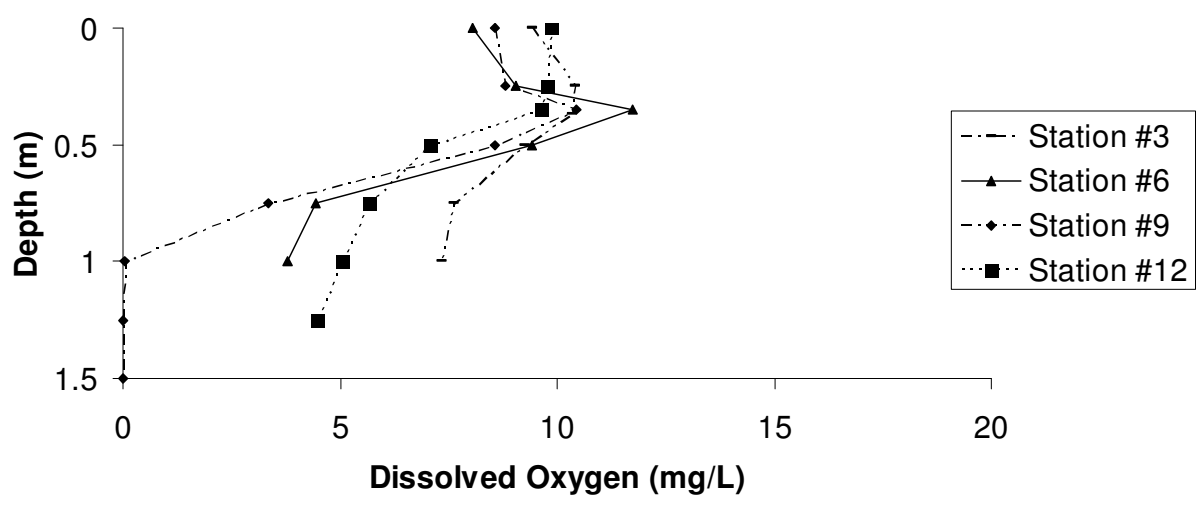

Figure 27. Dissolved oxygen (mg/L) at Stations \#3, 6, 9, and 12 on (a) August 04, (b) August 12, and (c) September 09, 2005 in San Gregorio Creek lagoon, San Mateo County. 
a)

September 24, 2005

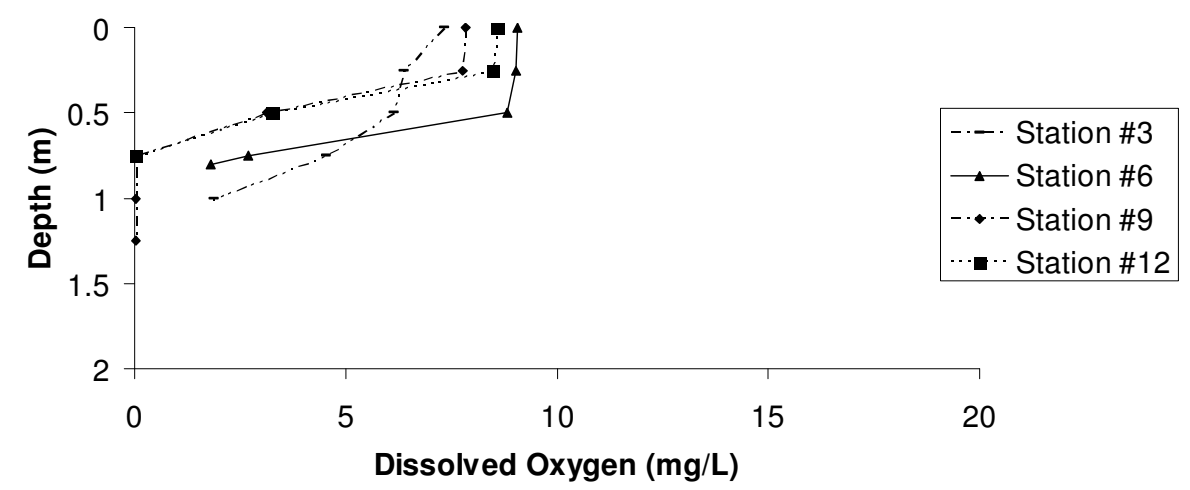

b)

October 14, 2005

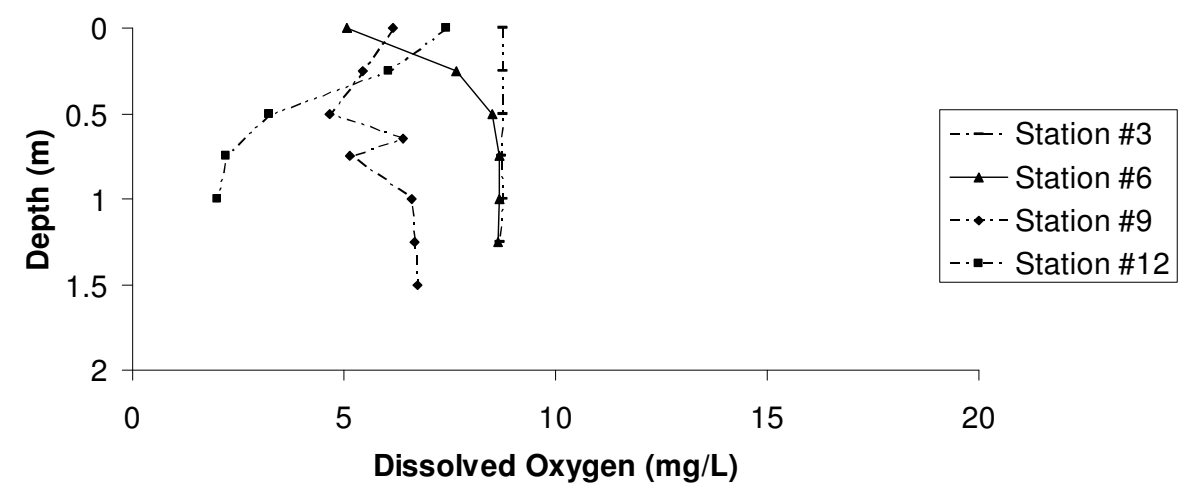

c)

October 29, 2005

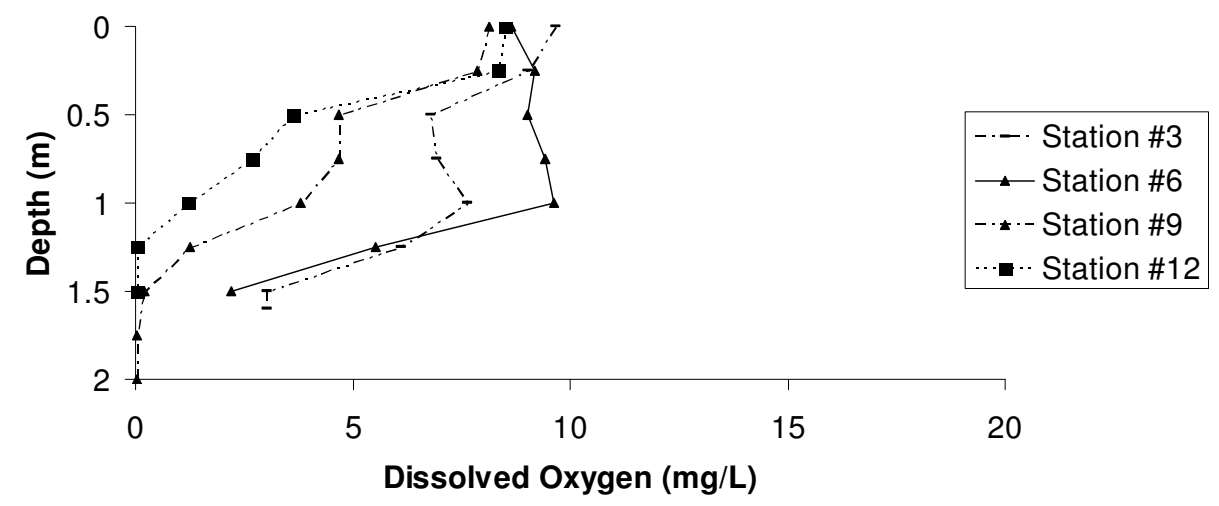

Figure 28. Dissolved oxygen (mg/L) at Stations \#3, 6, 9, and 12 on (a) September 24, (b) October 14, and (c) October 29, 2005 in San Gregorio Creek lagoon, San Mateo County. 
a)

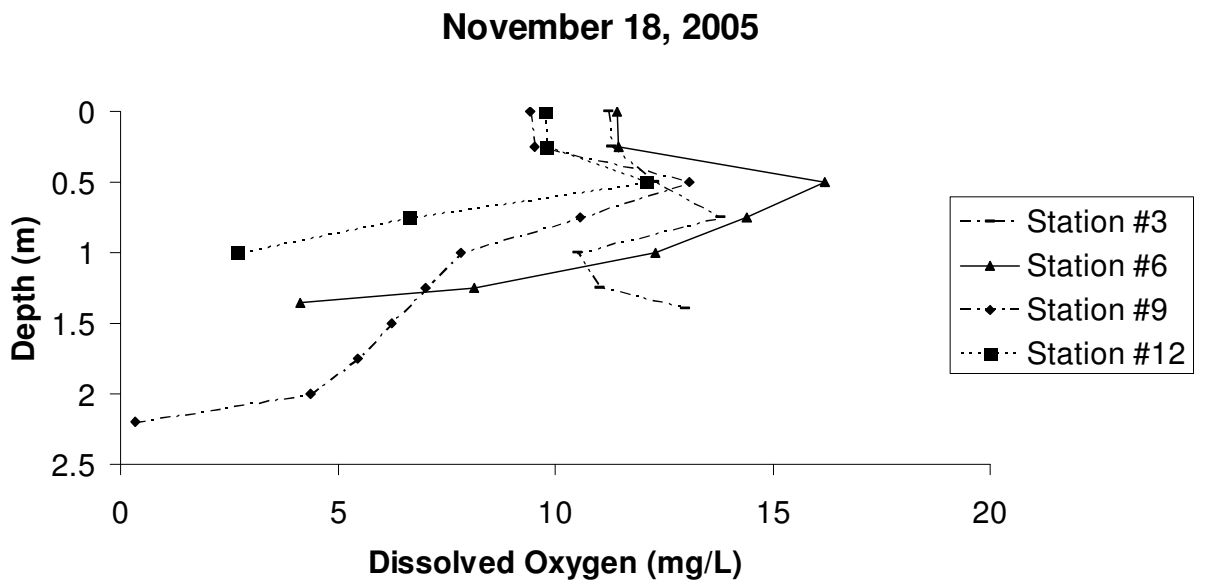

b)

December 02, 2005

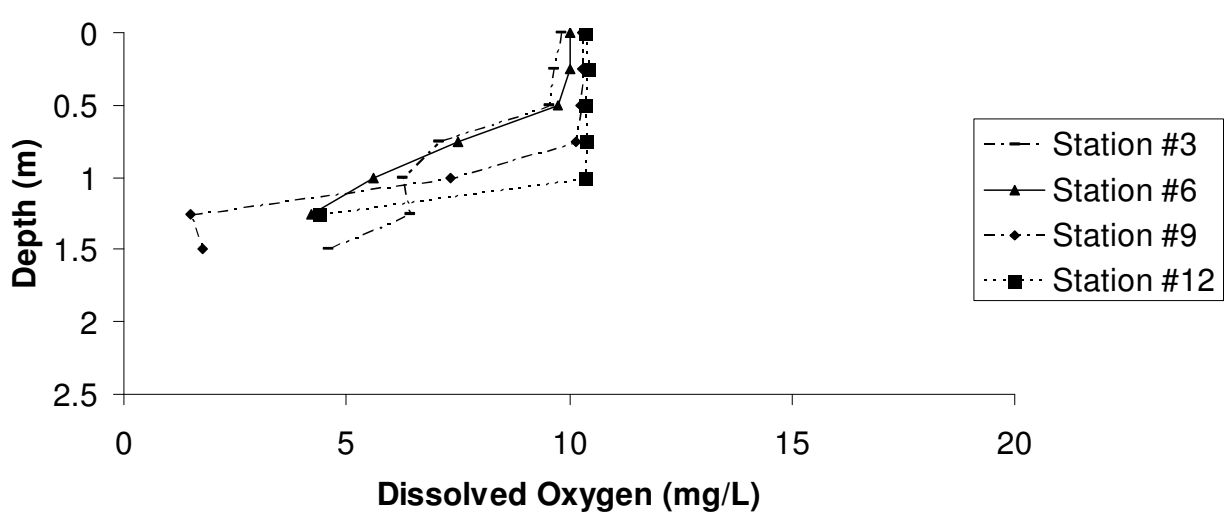

Figure 29. Dissolved oxygen (mg/L) at Stations \#3, 6, 9, and 12 on (a) November 18 and (b) December 02, 2005 in San Gregorio Creek lagoon, San Mateo County. 
a)

February 16, 2006

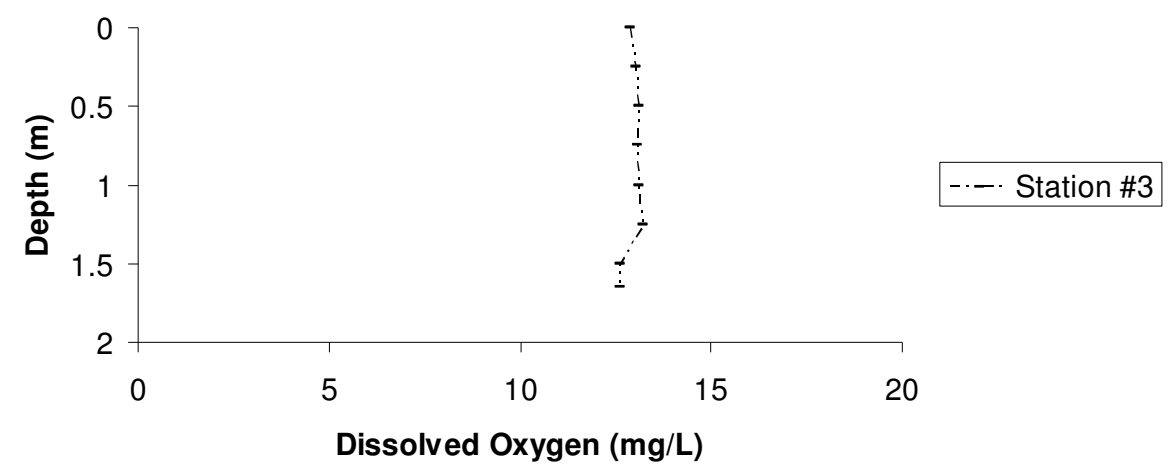

b)

March 16, 2006

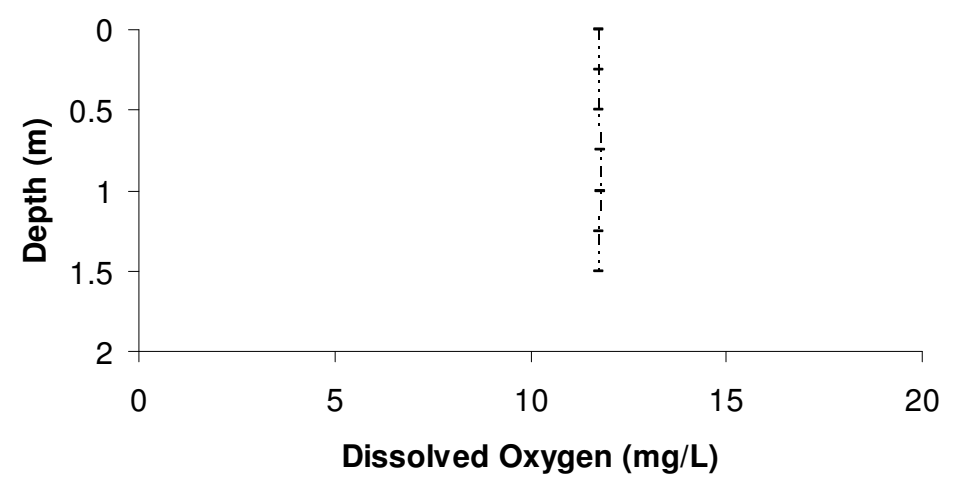

c)

April 13, 2006

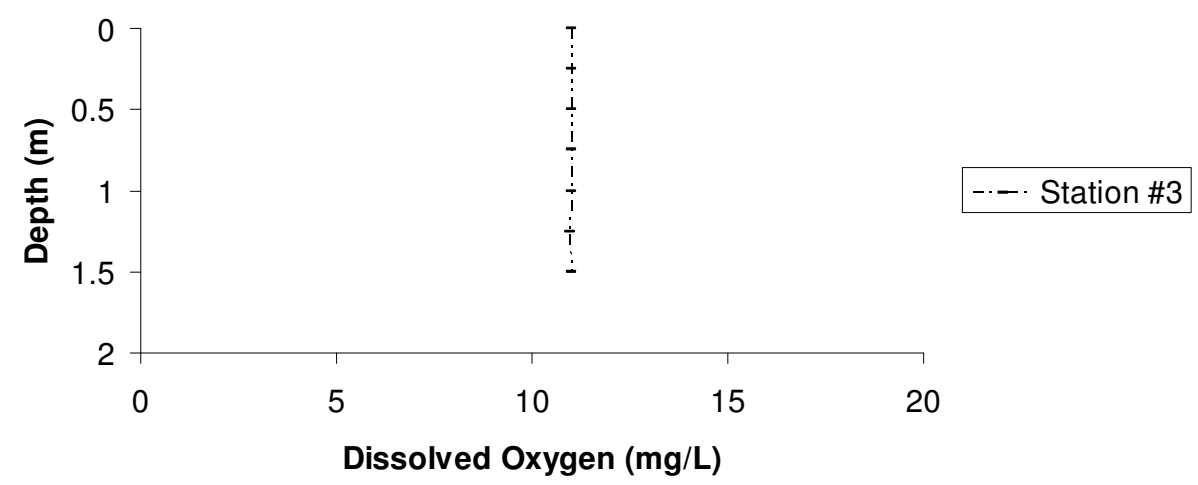

Figure 30. Dissolved oxygen (mg/L) at Station \#3 on (a) February 16, (b) March 16, and (c) April 13, 2006 in San Gregorio Creek lagoon, San Mateo County. 
a)

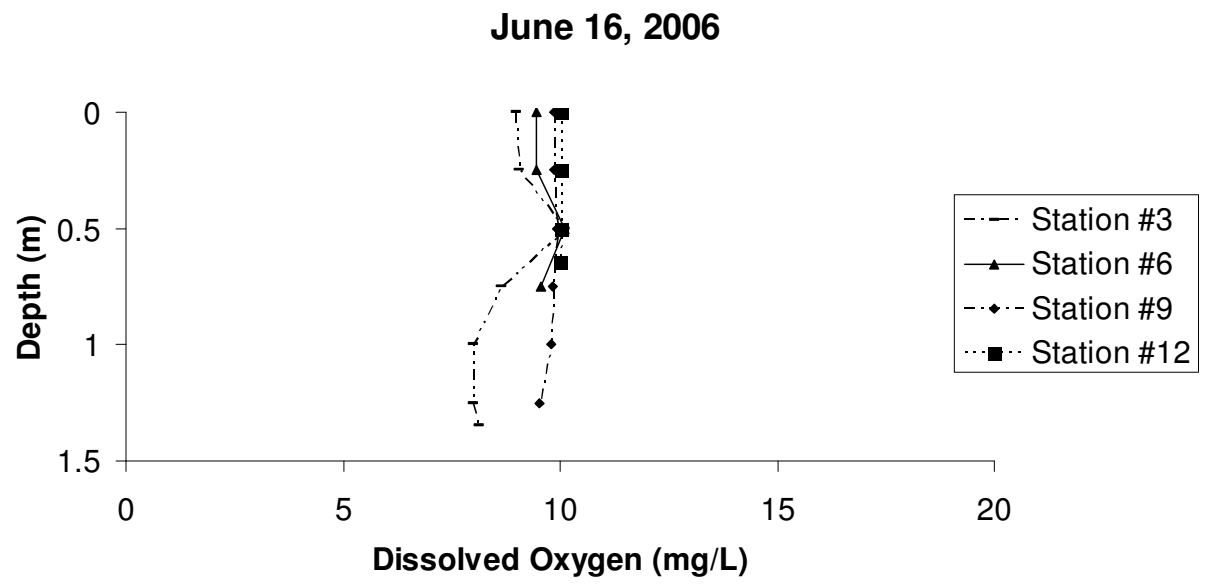

b)

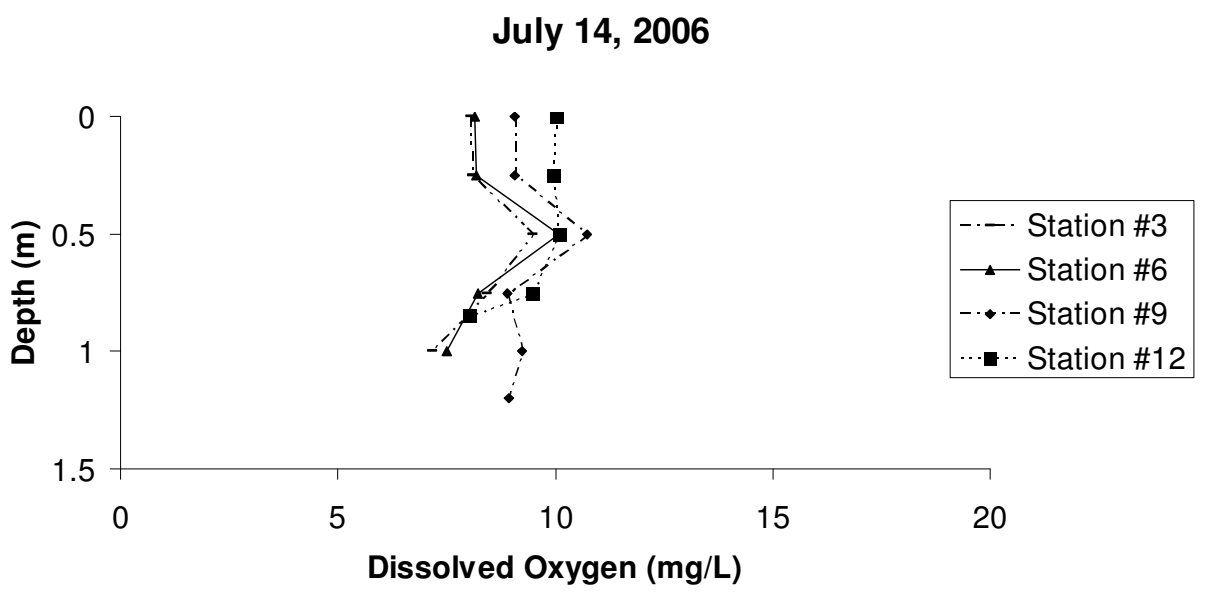

Figure 31. Dissolved oxygen (mg/L) at Stations \#3, 6, 9, and 12 on (a) June 16 and (b) July 14, 2006 in San Gregorio Creek lagoon, San Mateo County. 
a)

August 11, 2006 (Morning)

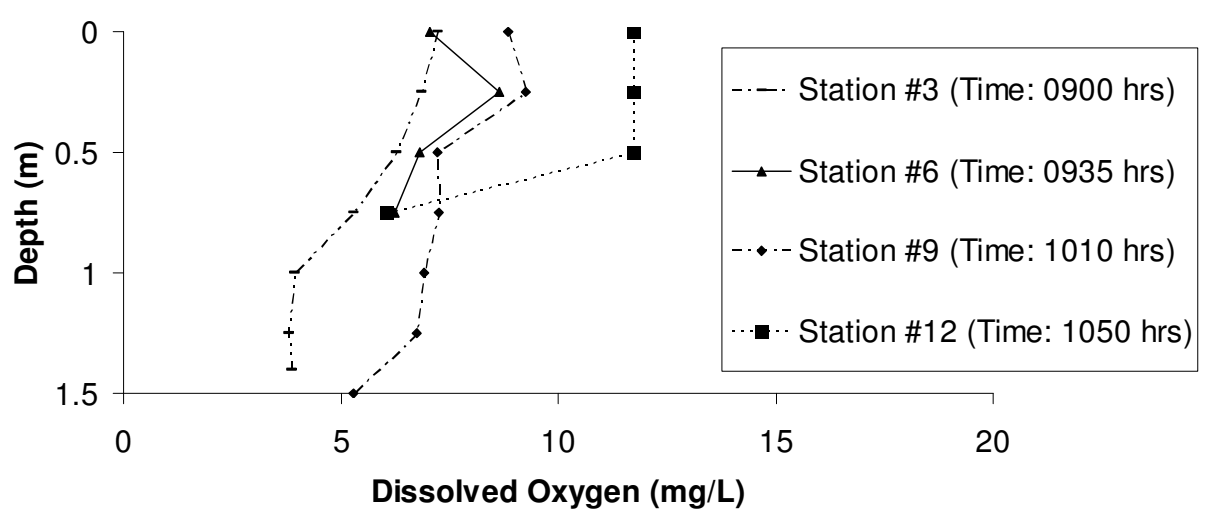

b)

August 11, 2006 (Late Morning)

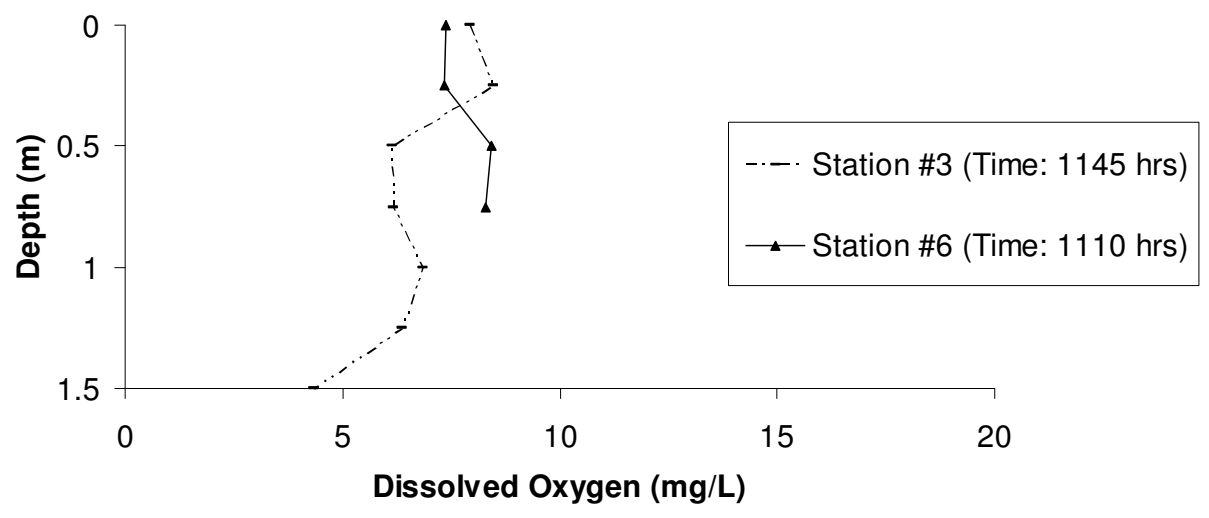

Figure 32. Dissolved oxygen (mg/L) at Stations \#3, 6, 9, and 12 (a) in the morning and at Stations \#3 and \#6 in the (b) late morning on August 16, 2005 in San Gregorio Creek lagoon, San Mateo County. 
a)

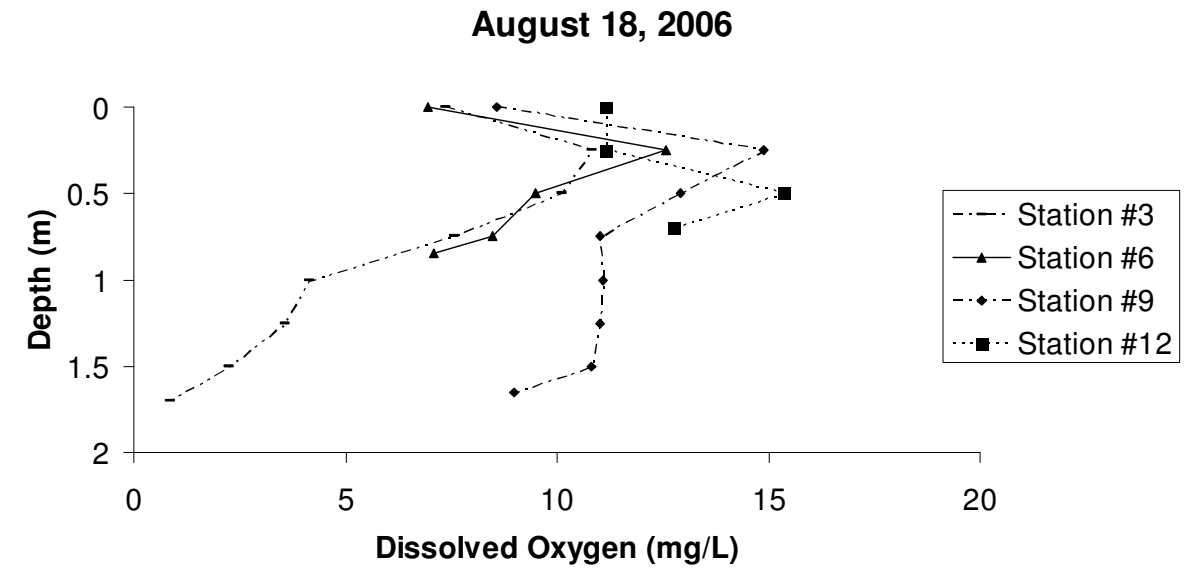

b)

September 08, 2006

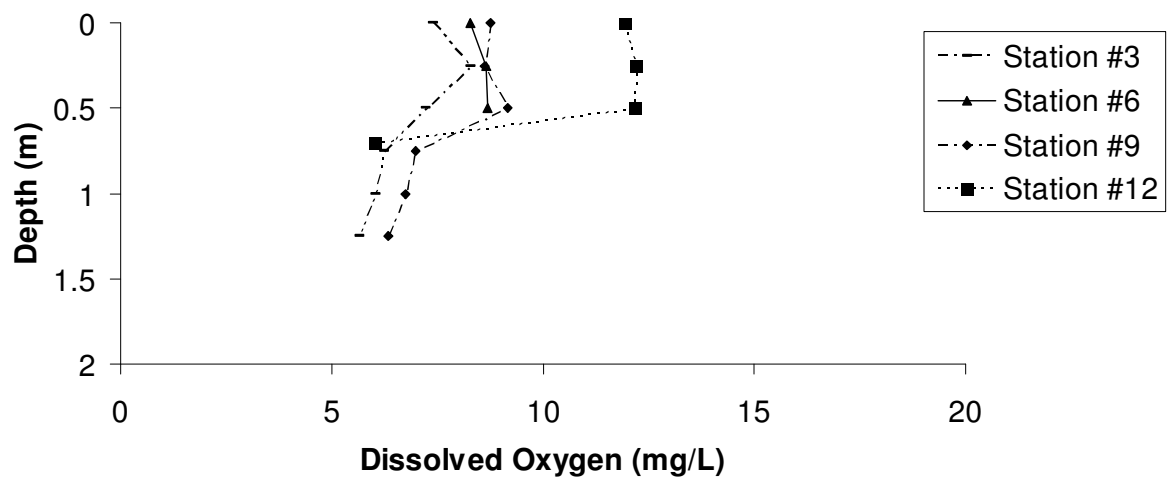

c)

September 15, 2006

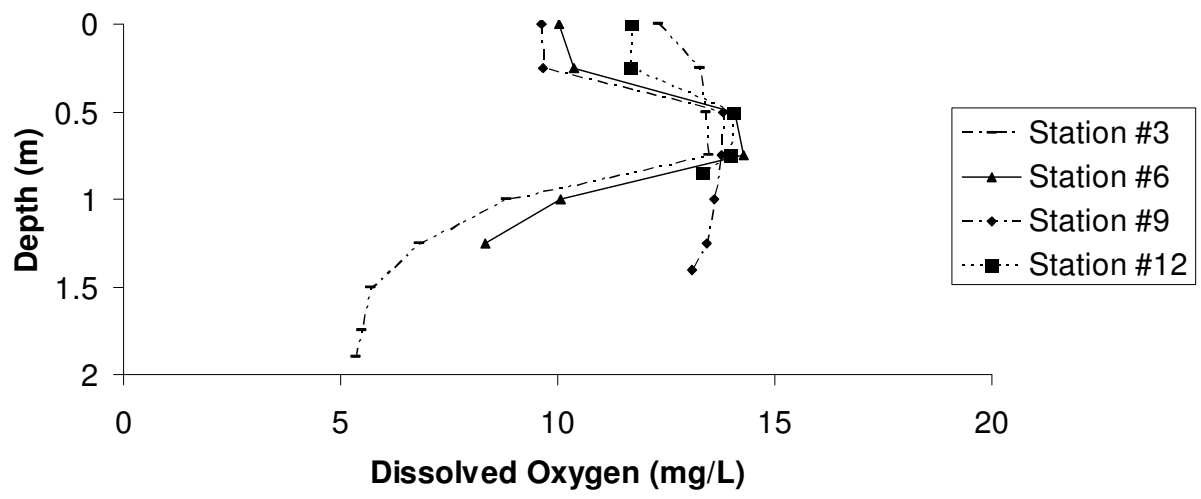

Figure 33. Dissolved oxygen (mg/L) at Stations \#3, 6, 9, and 12 on (a) August 18, (b) September 08, and (c) September 15, 2006 in San Gregorio Creek lagoon, San Mateo County. 
a)

October 05, 2006

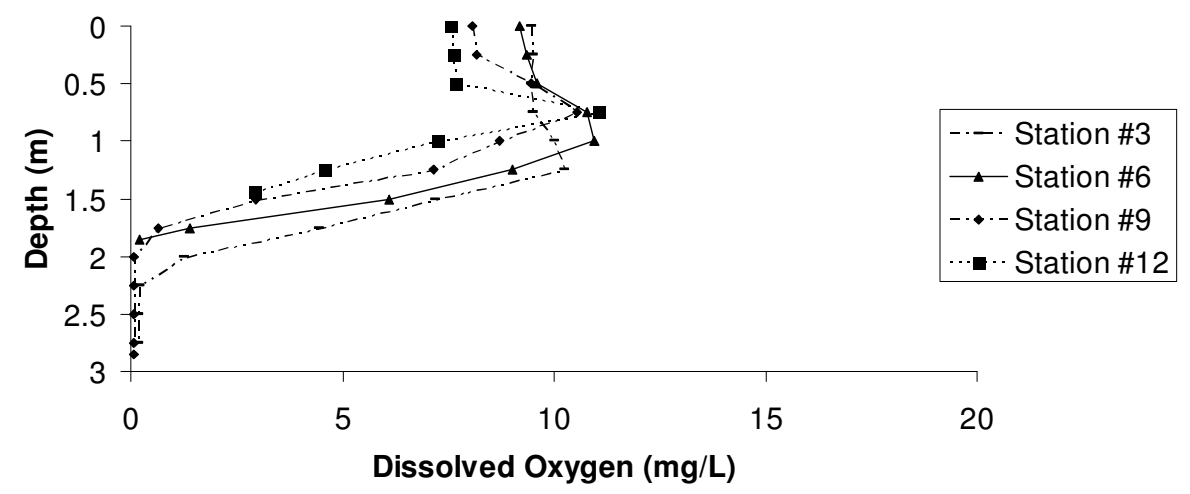

b)

November 02, 2006

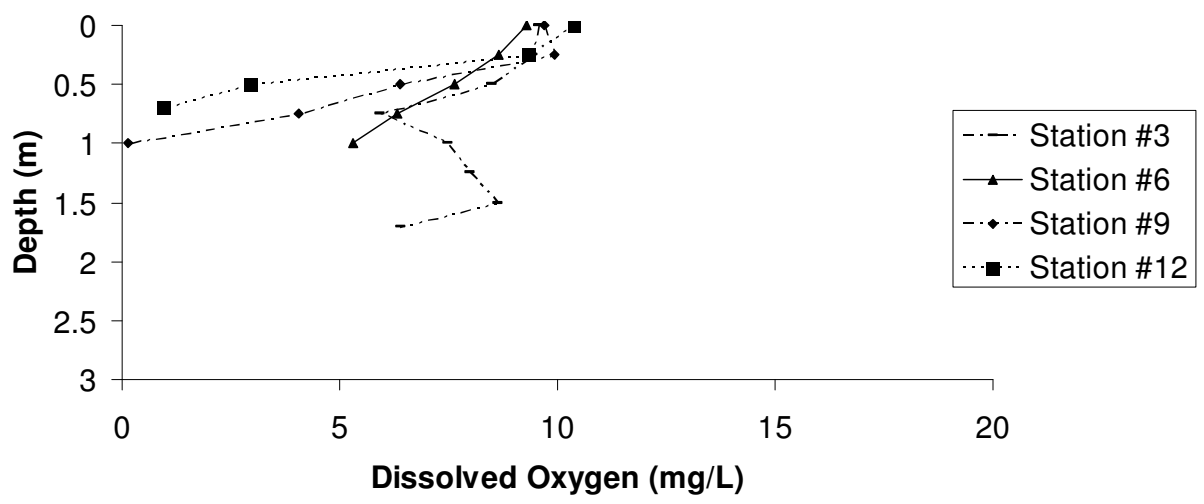

c)

November 30, 2006

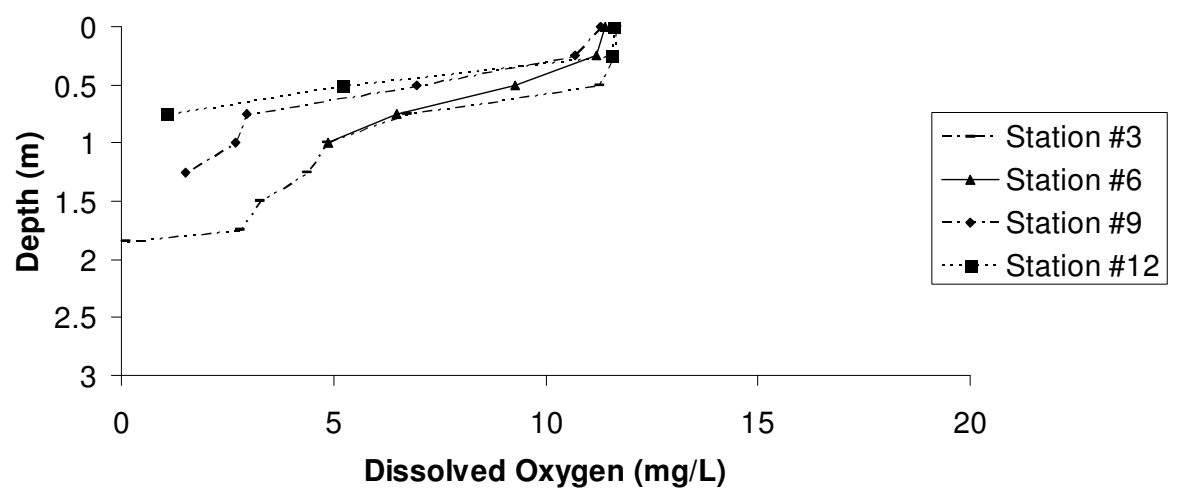

Figure 34. Dissolved oxygen (mg/L) at Stations \#3, 6, 9, and 12 on (a) October 05, (b) November 02, and (c) November 30, 2006 in San Gregorio Creek lagoon, San Mateo County. 
April 18, 2008

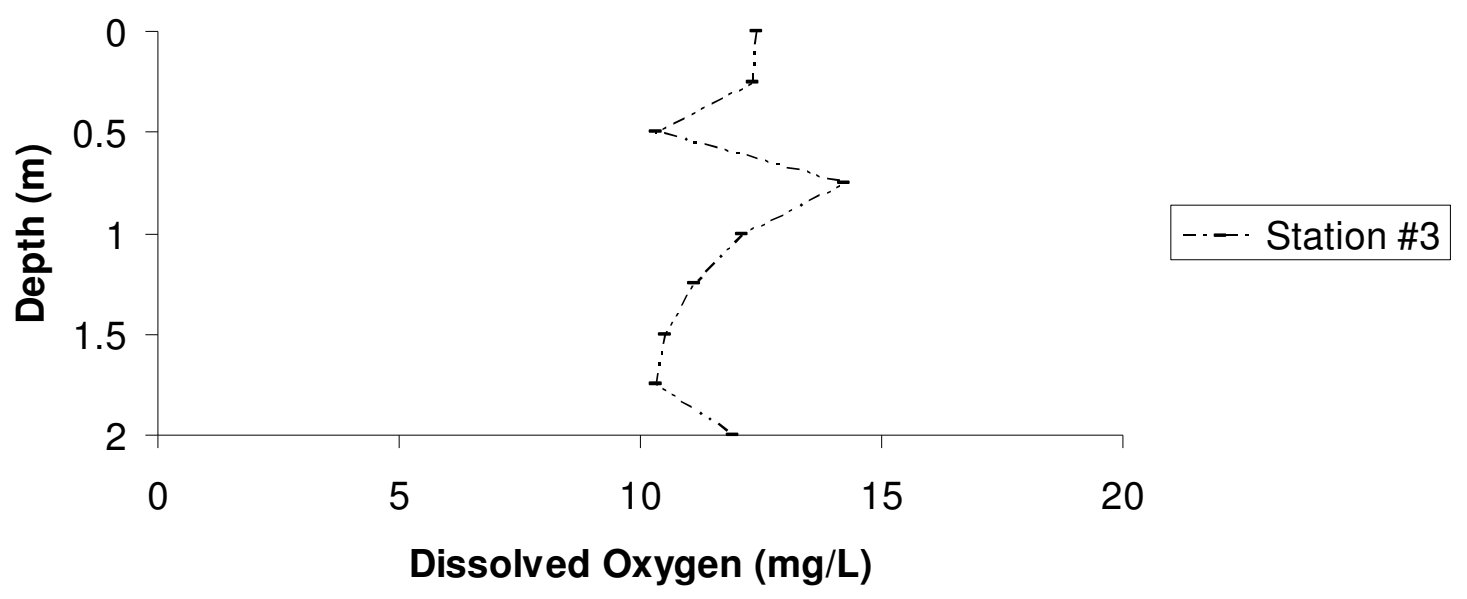

Figure 35. Dissolved oxygen (mg/L) at Station \#3 April 18, 2008 in San Gregorio Creek lagoon, San Mateo County. 


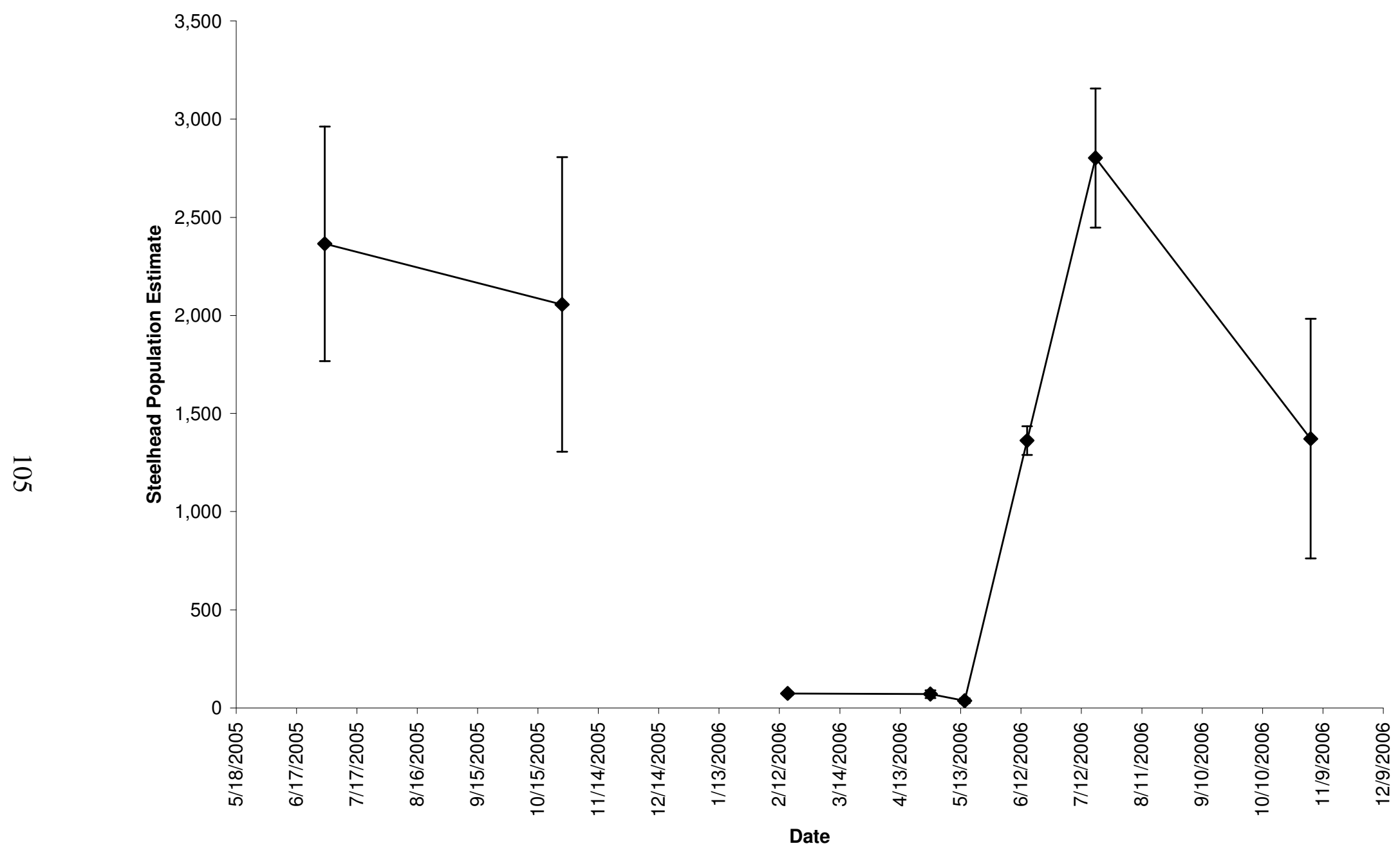

Figure 36. Population estimates and confidence intervals of steelhead from the period of July 01, 2005 to November 03, 2006 in San Gregorio Creek lagoon, San Mateo County 
a)

July 01, 2005

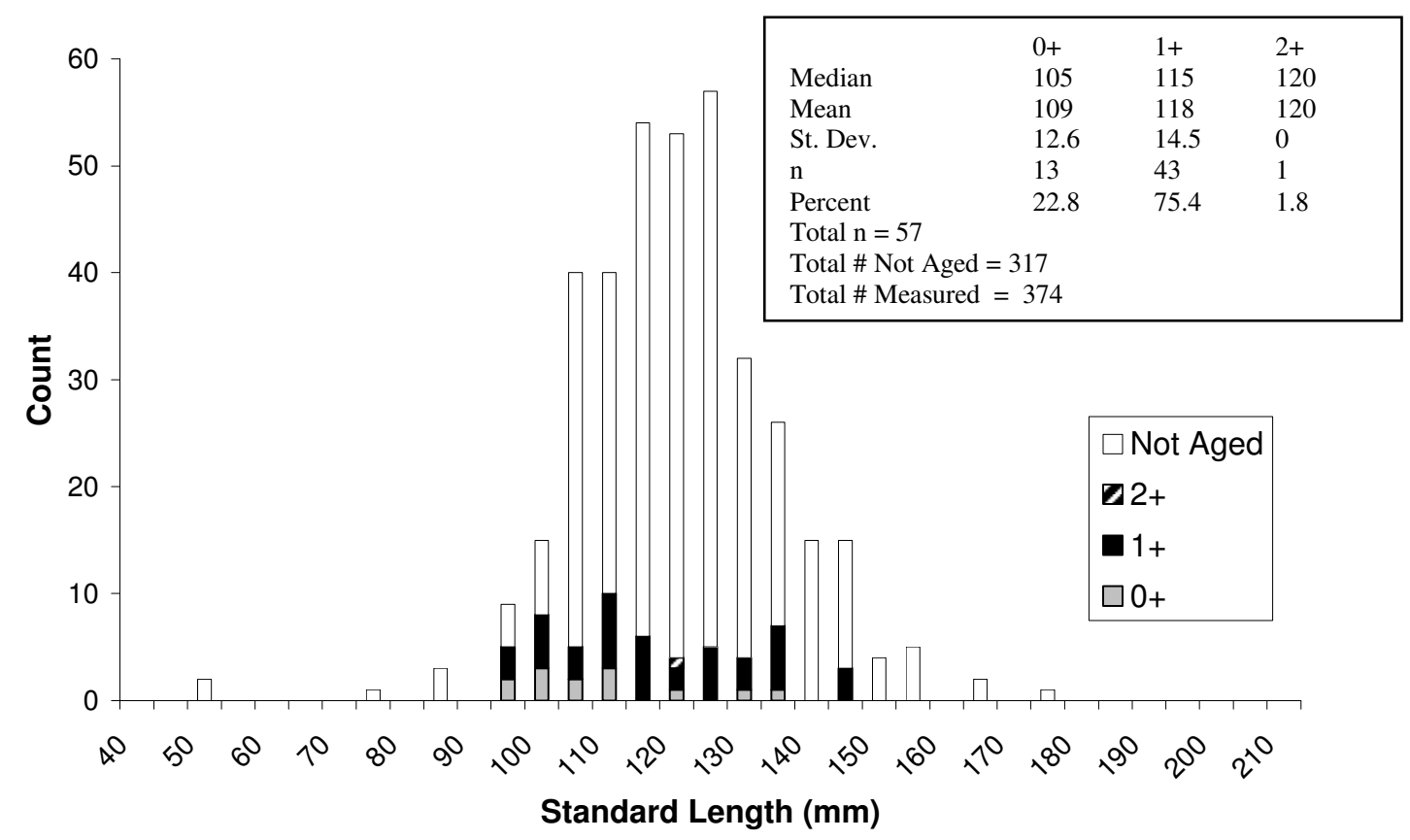

b)

October 27, 2005

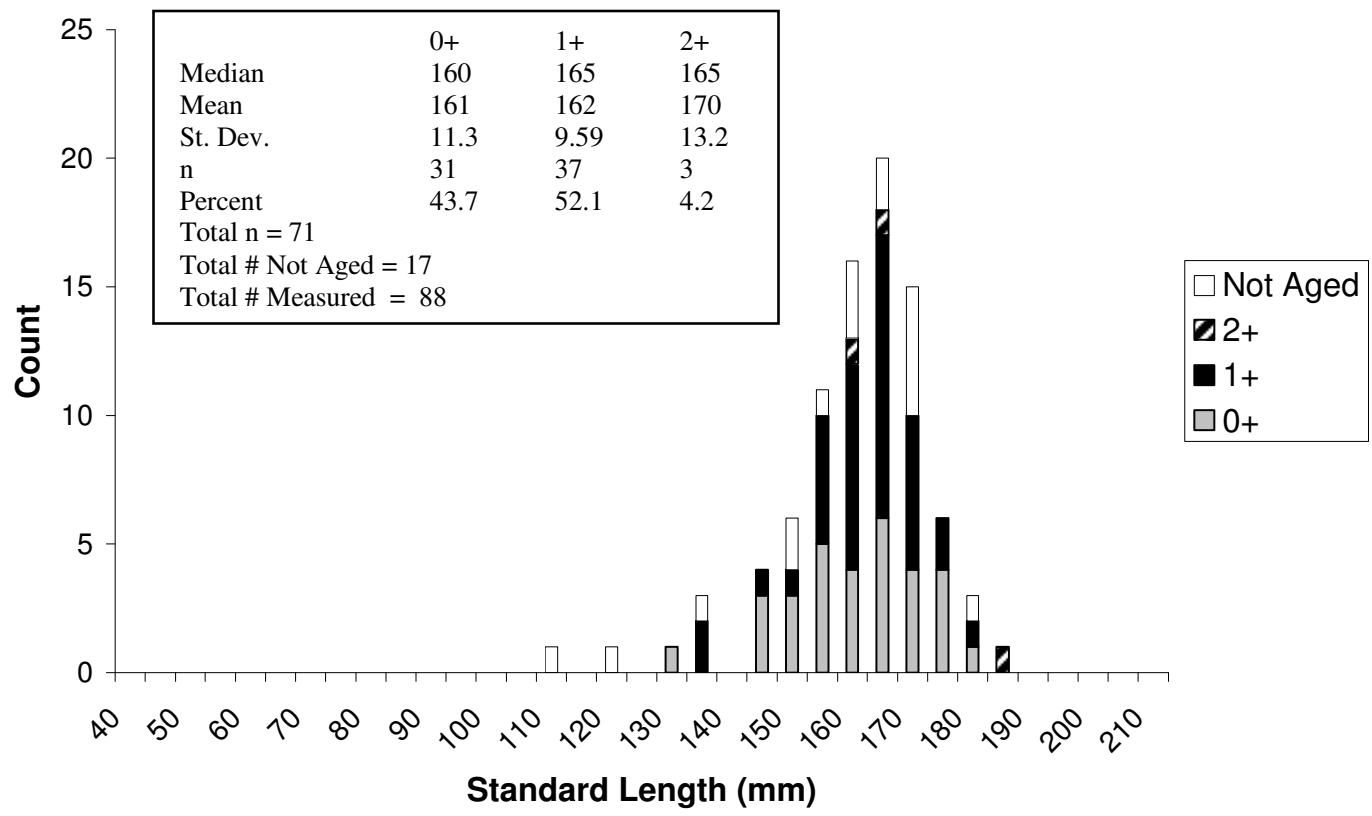

Figure 37. Standard length (mm) of steelhead of different ages on (a) July 01 and (b) October 27, 2005 at San Gregorio Creek lagoon, San Mateo County. 


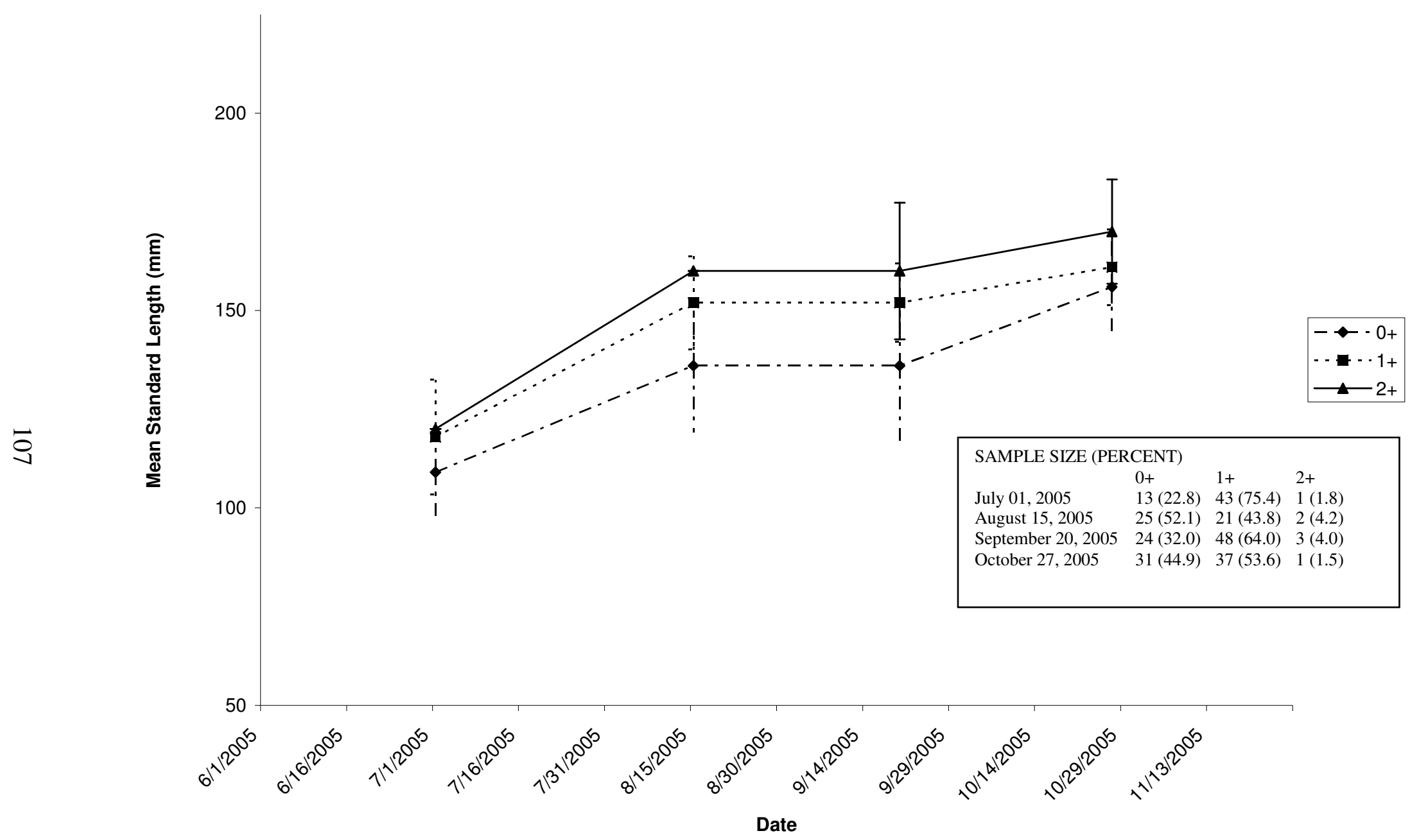

Figure 38. Mean standard lengths (mm) of steelhead of different ages from the period of July 01 to October 27, 2005 in San Gregorio Creek lagoon, San Mateo County. 
a)

\section{November 15, 2005 (San Gregorio Creek)}

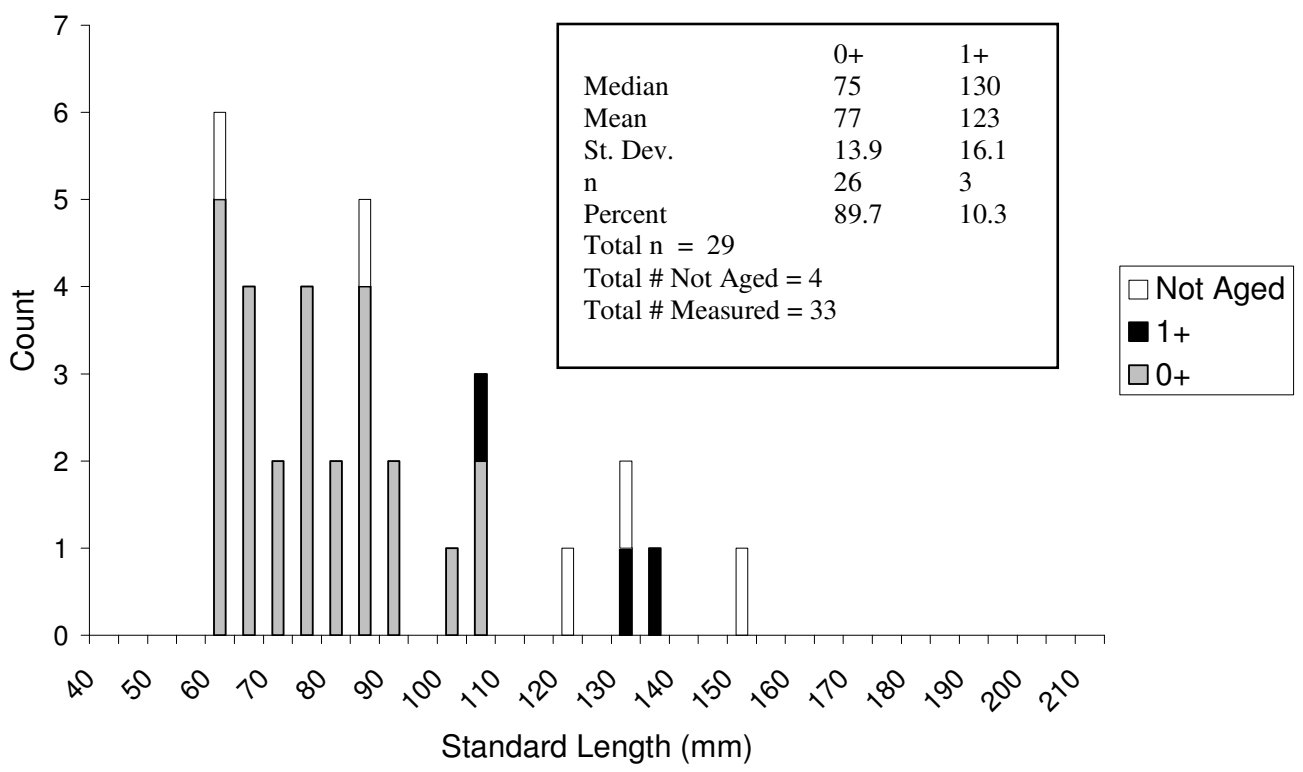

b)

November 15, 2005 (Alpine Creek)

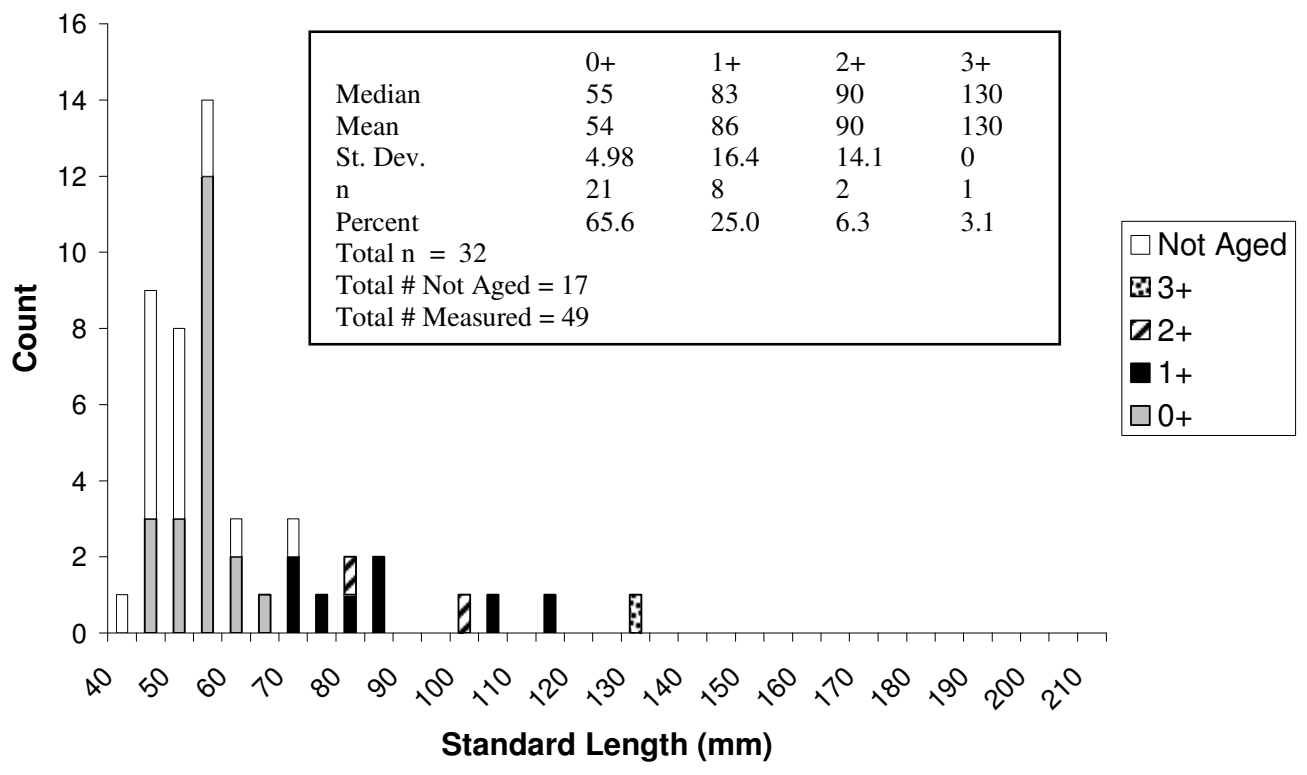

Figure 39. Standard length ( $\mathrm{mm})$ of steelhead of different ages on November 15, 2005 at (a) San Gregorio Creek and (b) Alpine Creek. Both stations are located within the San Gregorio Creek watershed, San Mateo County. 
a)

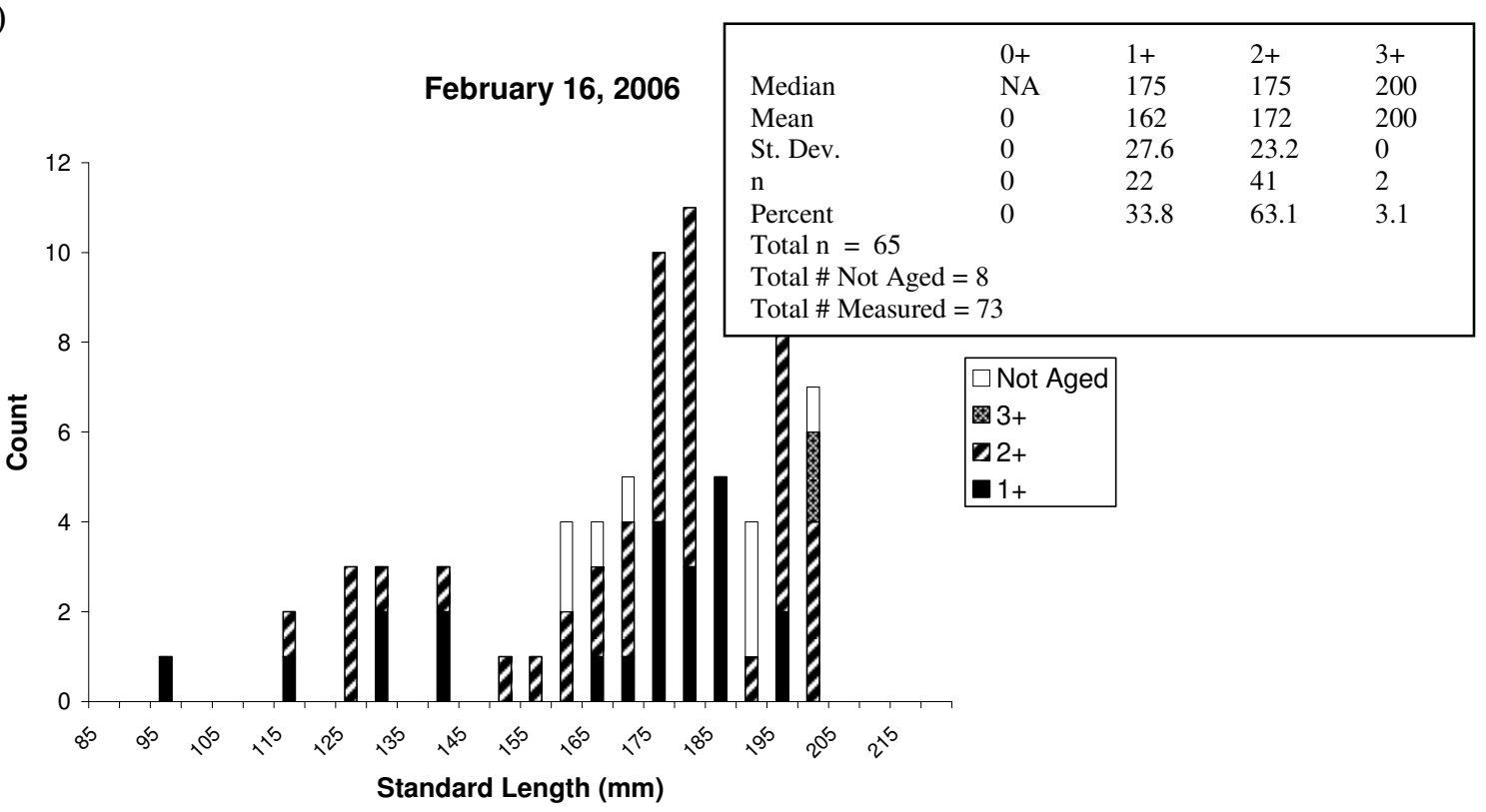

b)

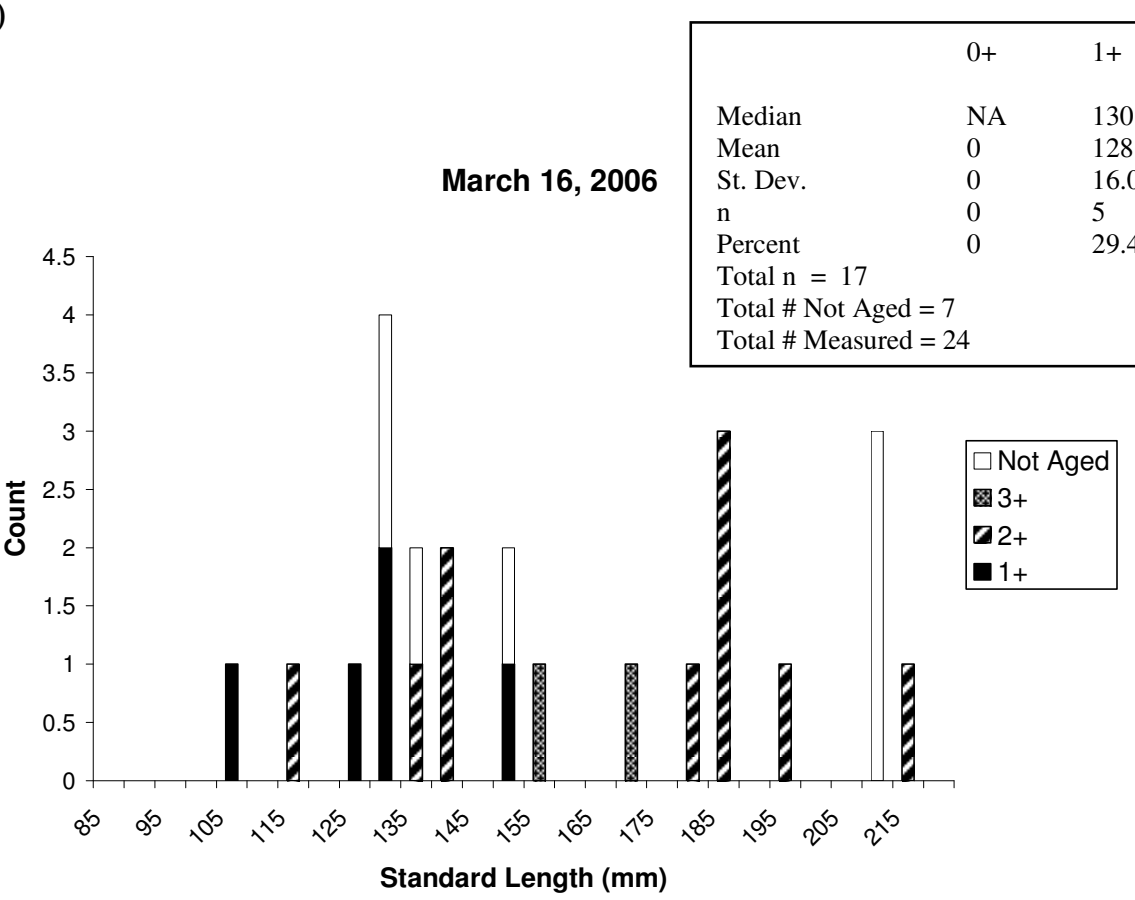

Figure 40. Standard length (mm) of steelhead of different ages on (a) February 16 and (b) March 16, 2006 in San Gregorio Creek lagoon, San Mateo County. All of the steelhead captured were smolts. 
a)

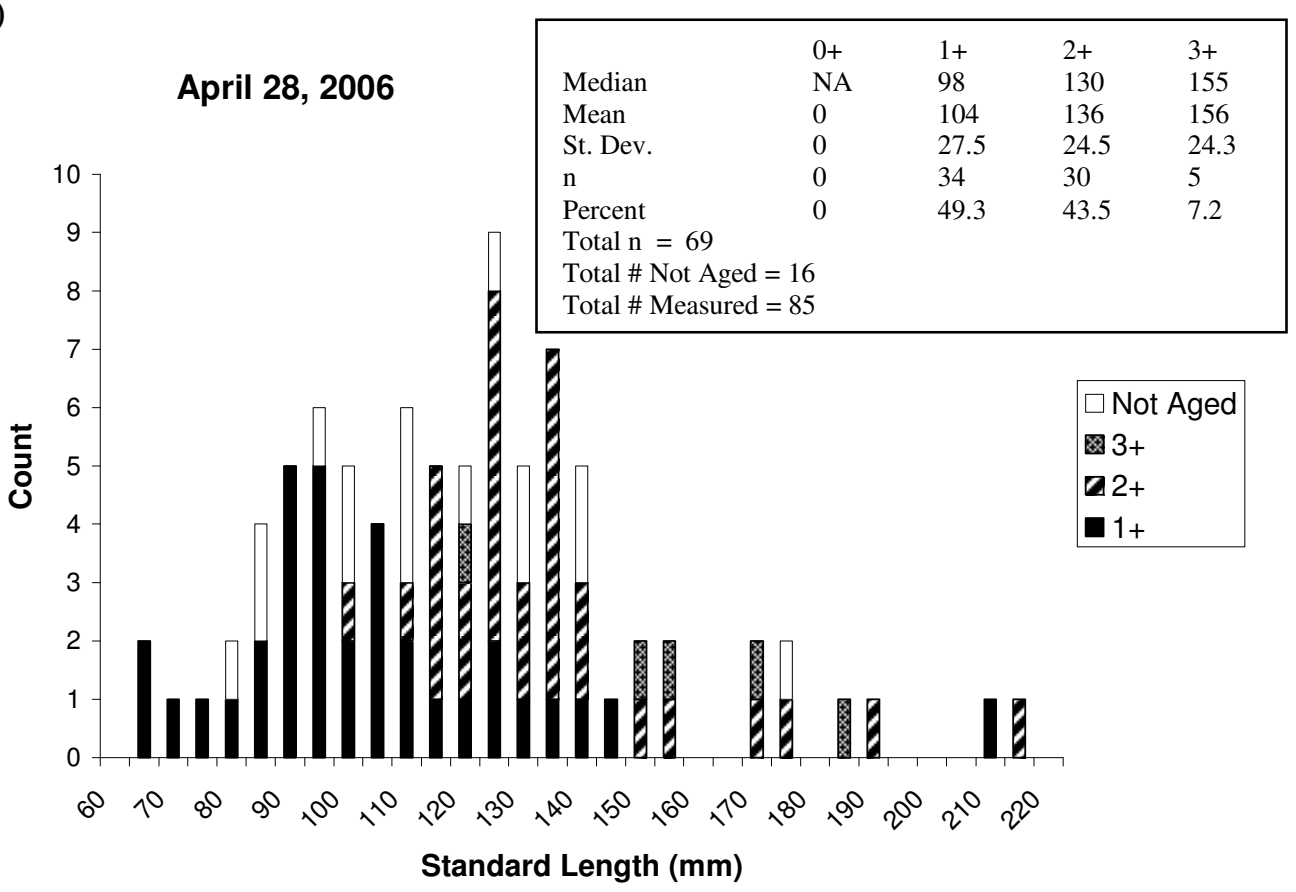

b)

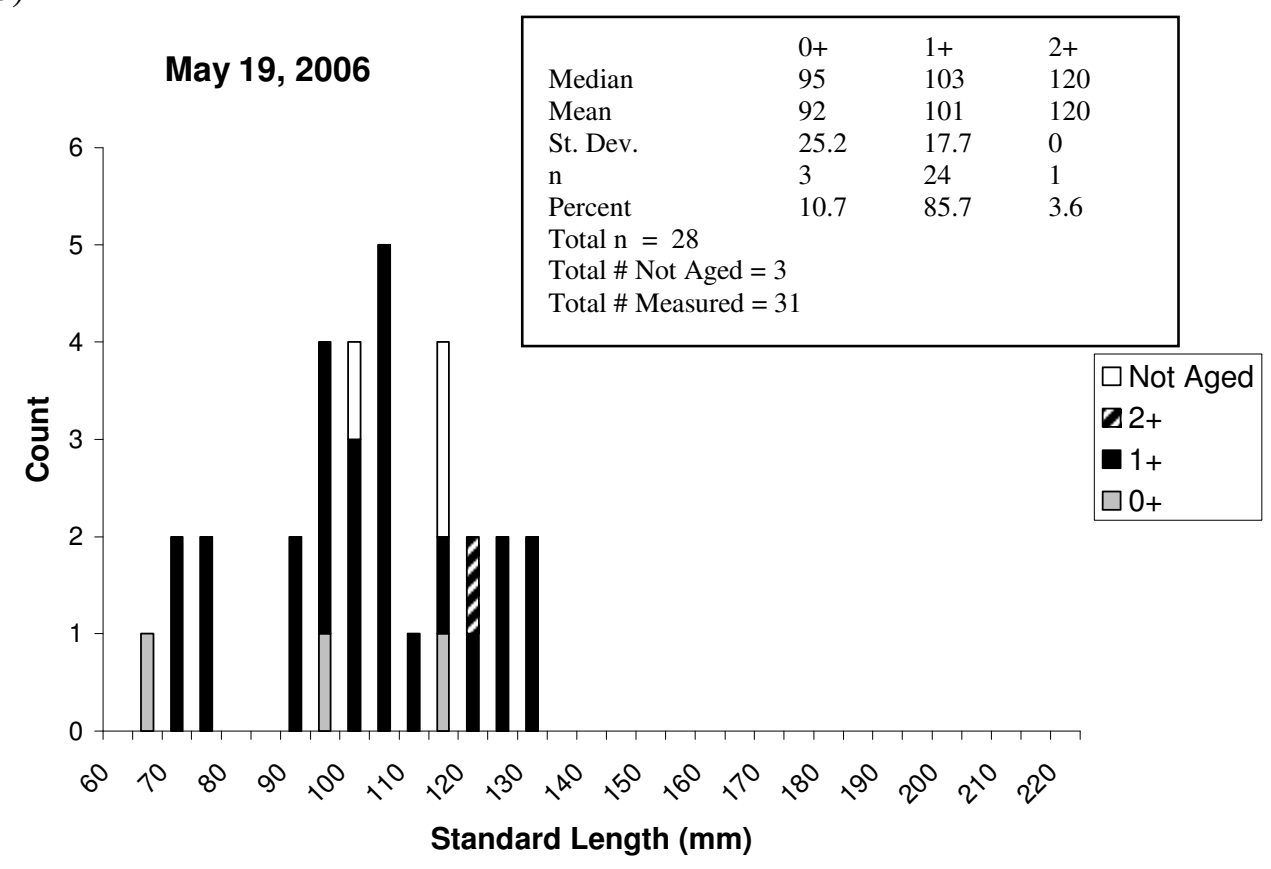

Figure 41. Standard length ( $\mathrm{mm}$ ) of juvenile steelhead of different ages on (a) April 28, 2006 and (b) May 19, 2006 in San Gregorio Creek lagoon, San Mateo County. Additionally, one jack (not in figure) was captured by hand on April 28, 2006. 


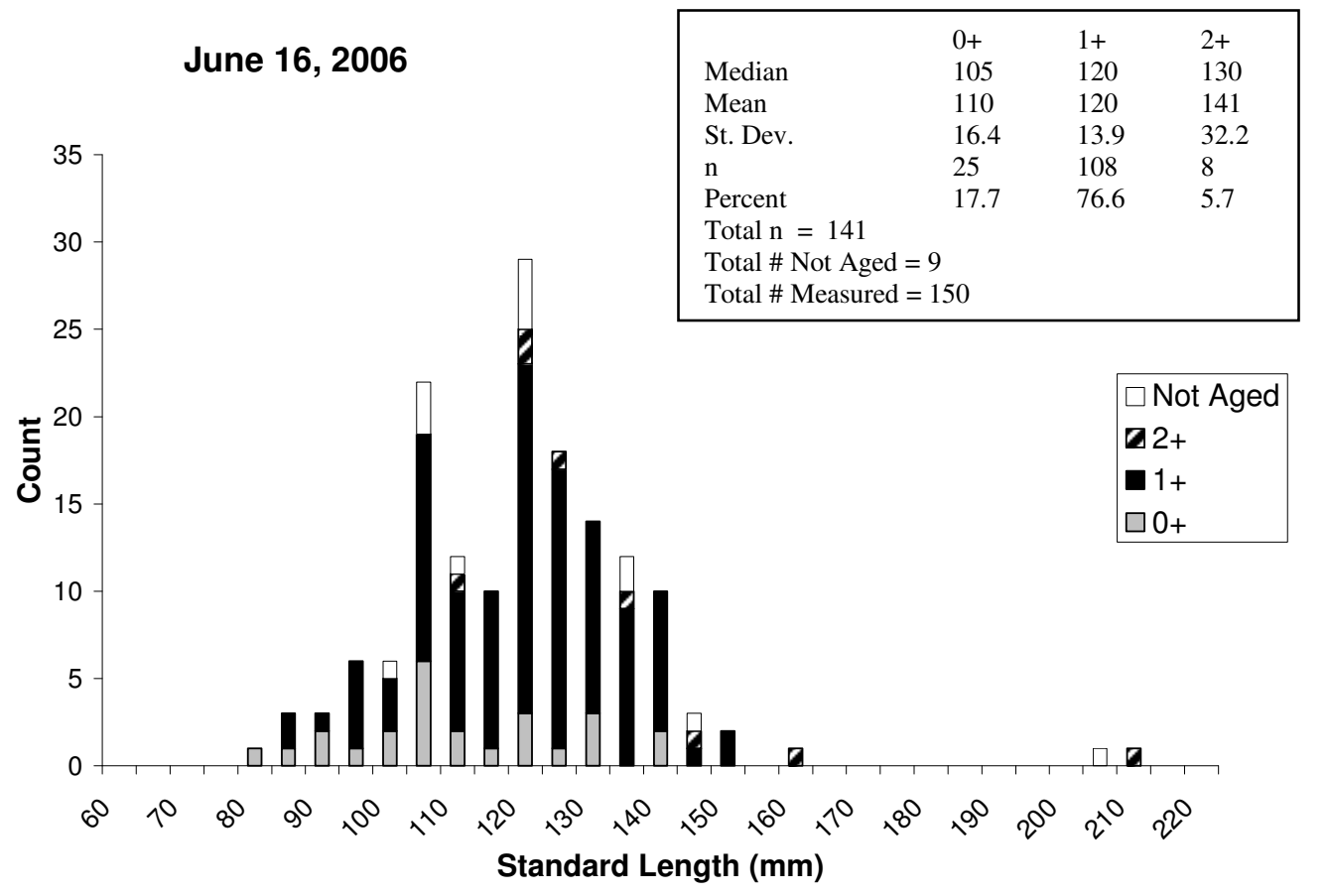

Figure 42. Standard length $(\mathrm{mm})$ of steelhead of different ages on June 16, 2006 in San Gregorio Creek lagoon, San Mateo County. 


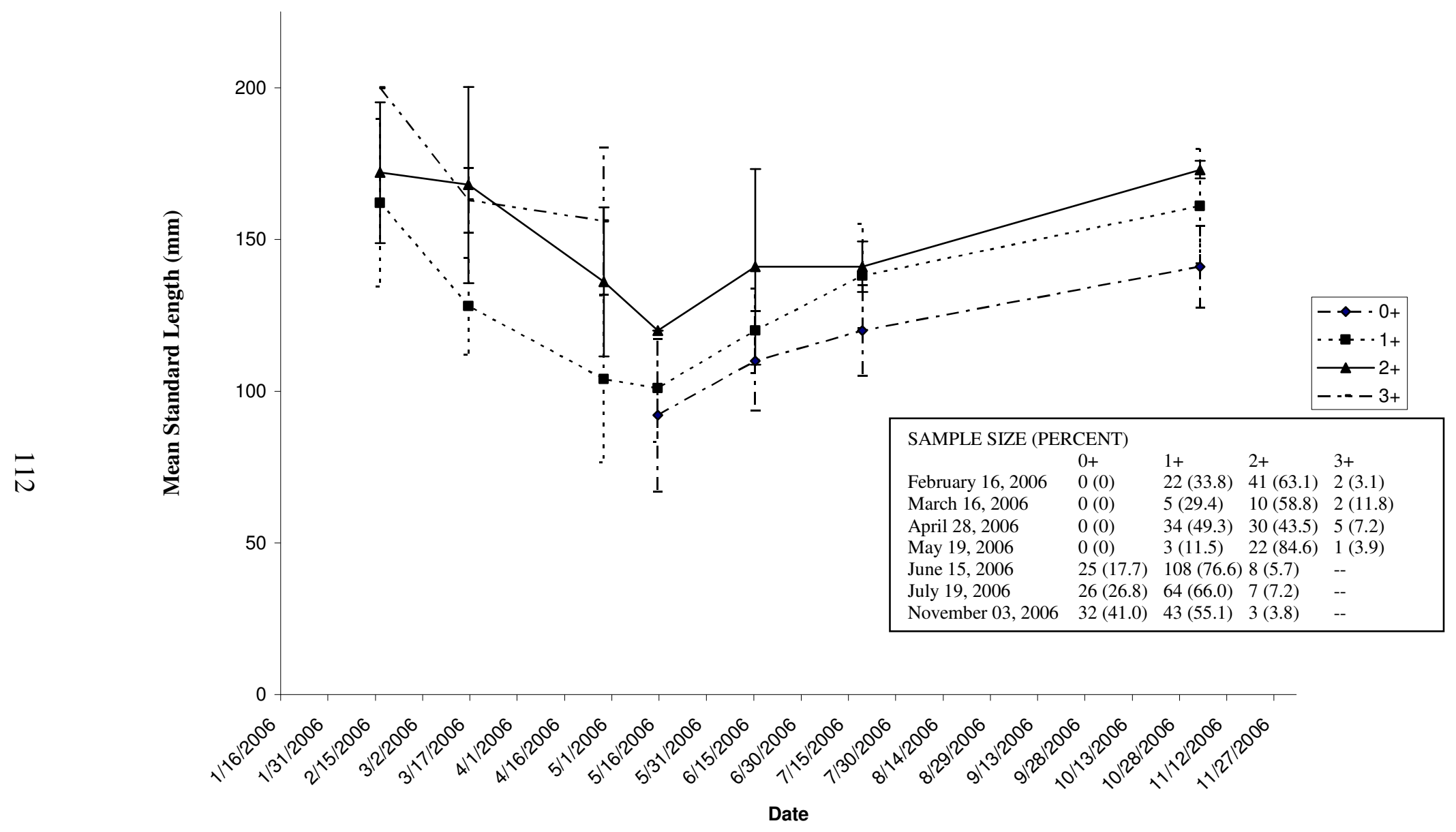

Figure 43. Mean standard lengths (mm) of juvenile steelhead of different ages from the period of February 16 to November 03, 2006 in San Gregorio Creek lagoon, San Mateo County. Additionally, one jack (not in figure) was captured by hand on April 28, 2006. 
a)

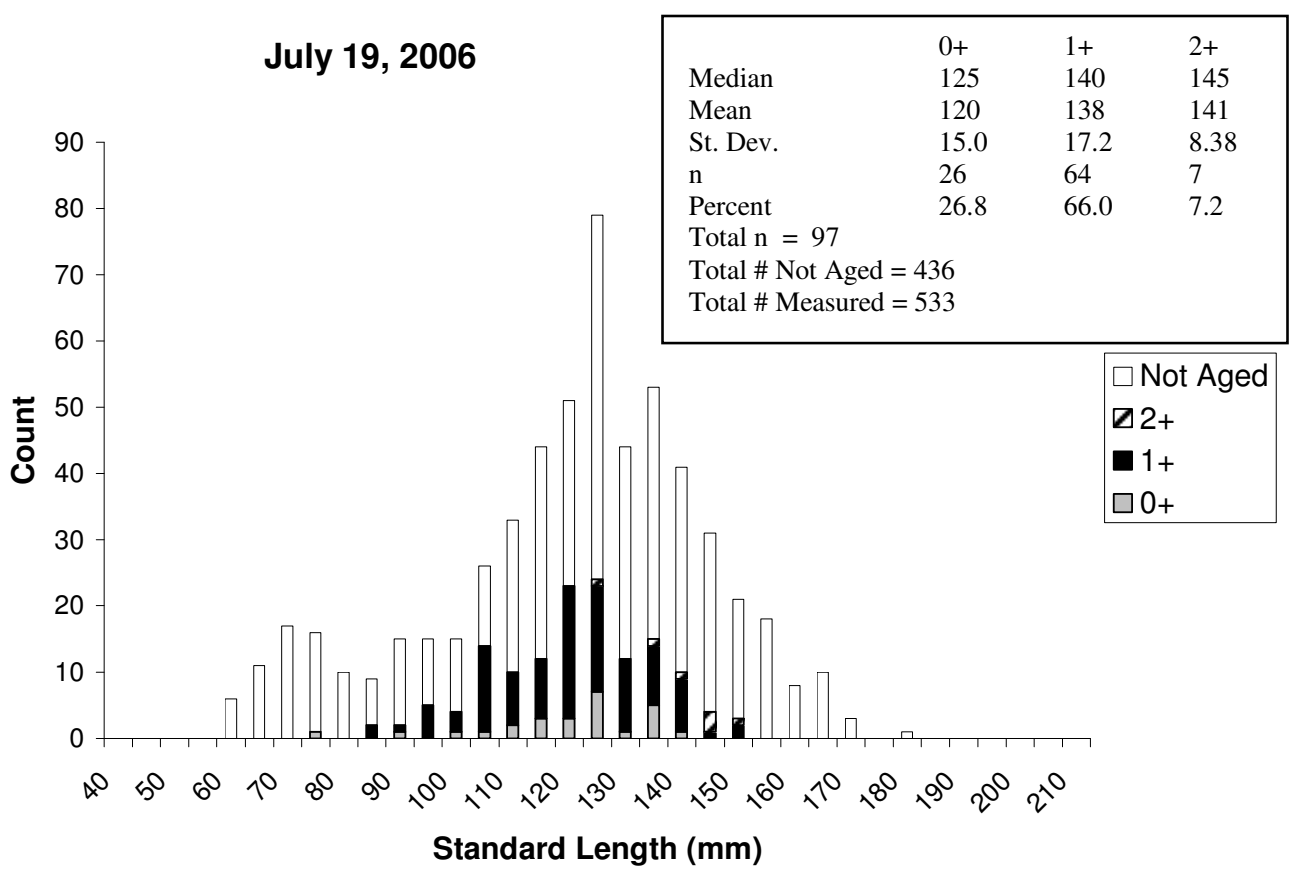

b)

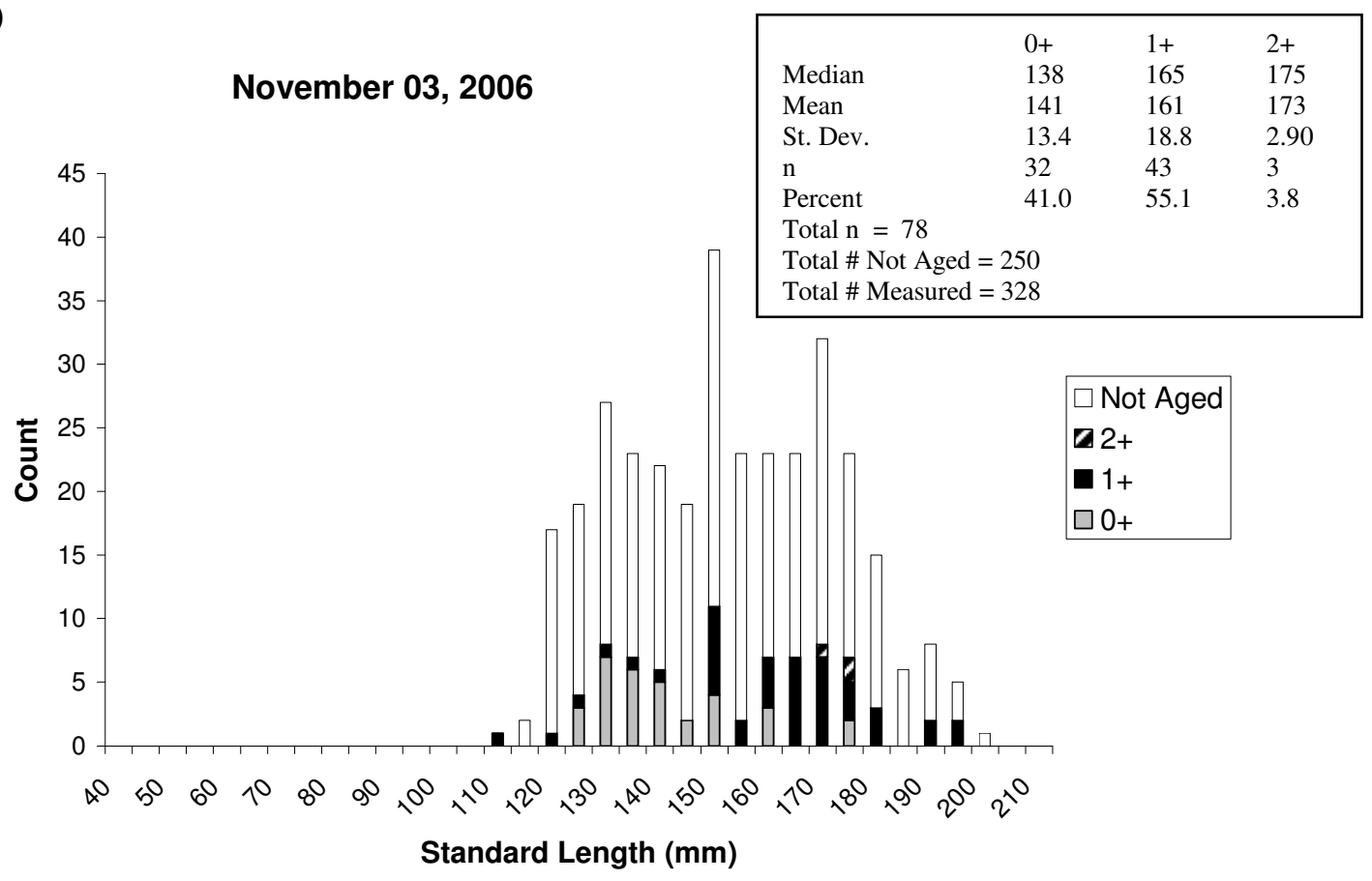

Figure 44. Standard length (mm) of steelhead of different ages on (a) July 19, 2006 and on (b) November 03, 2006 in San Gregorio Creek lagoon, San Mateo County 


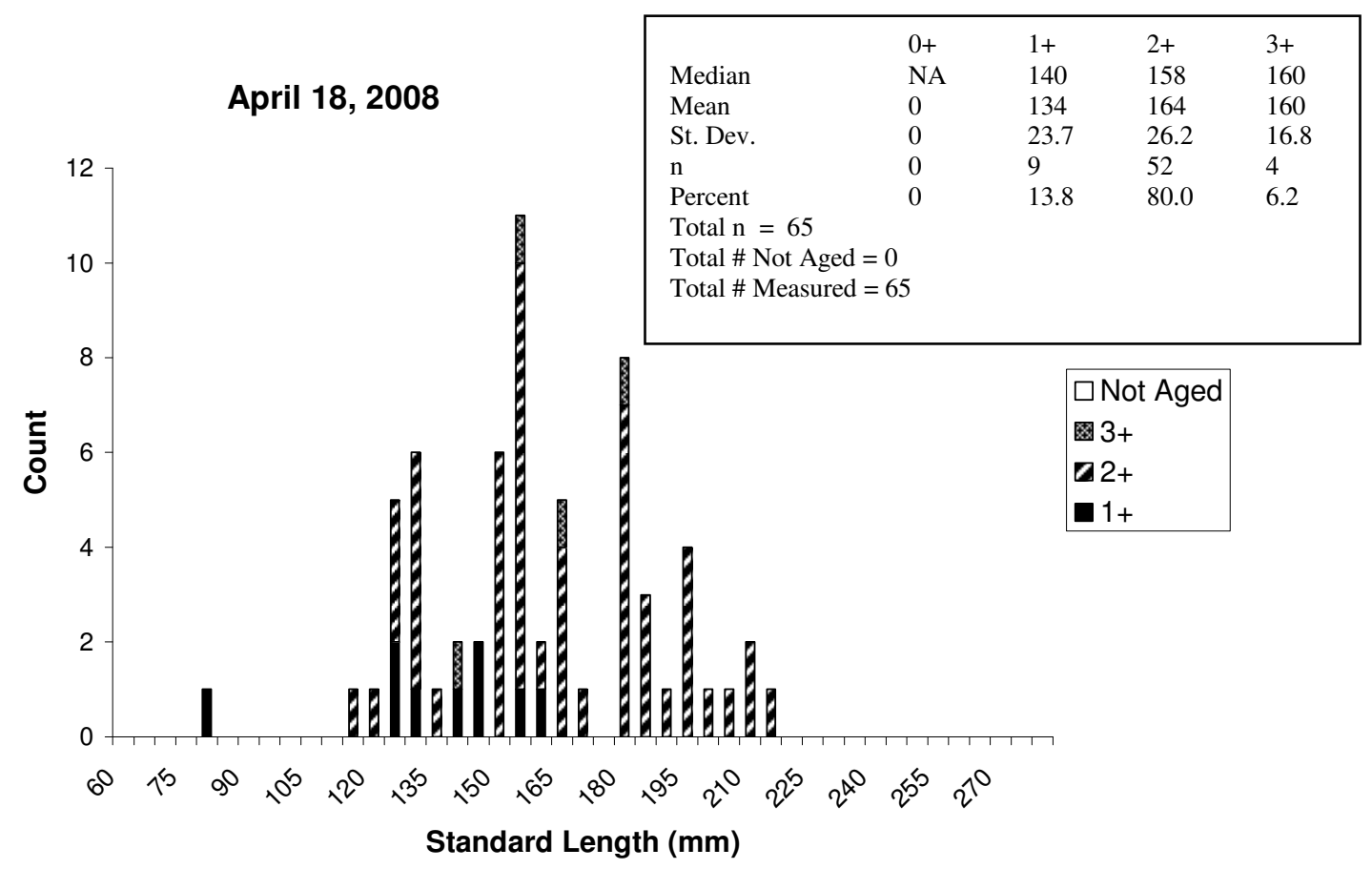

Figure 45. Standard length (mm) of juvenile steelhead of different on April 18, 2008 in San Gregorio Creek lagoon, San Mateo County. Also, 23 adult steelhead (not in figure) were captured on this date. Nearly all of the juvenile steelhead captured were smolts. 


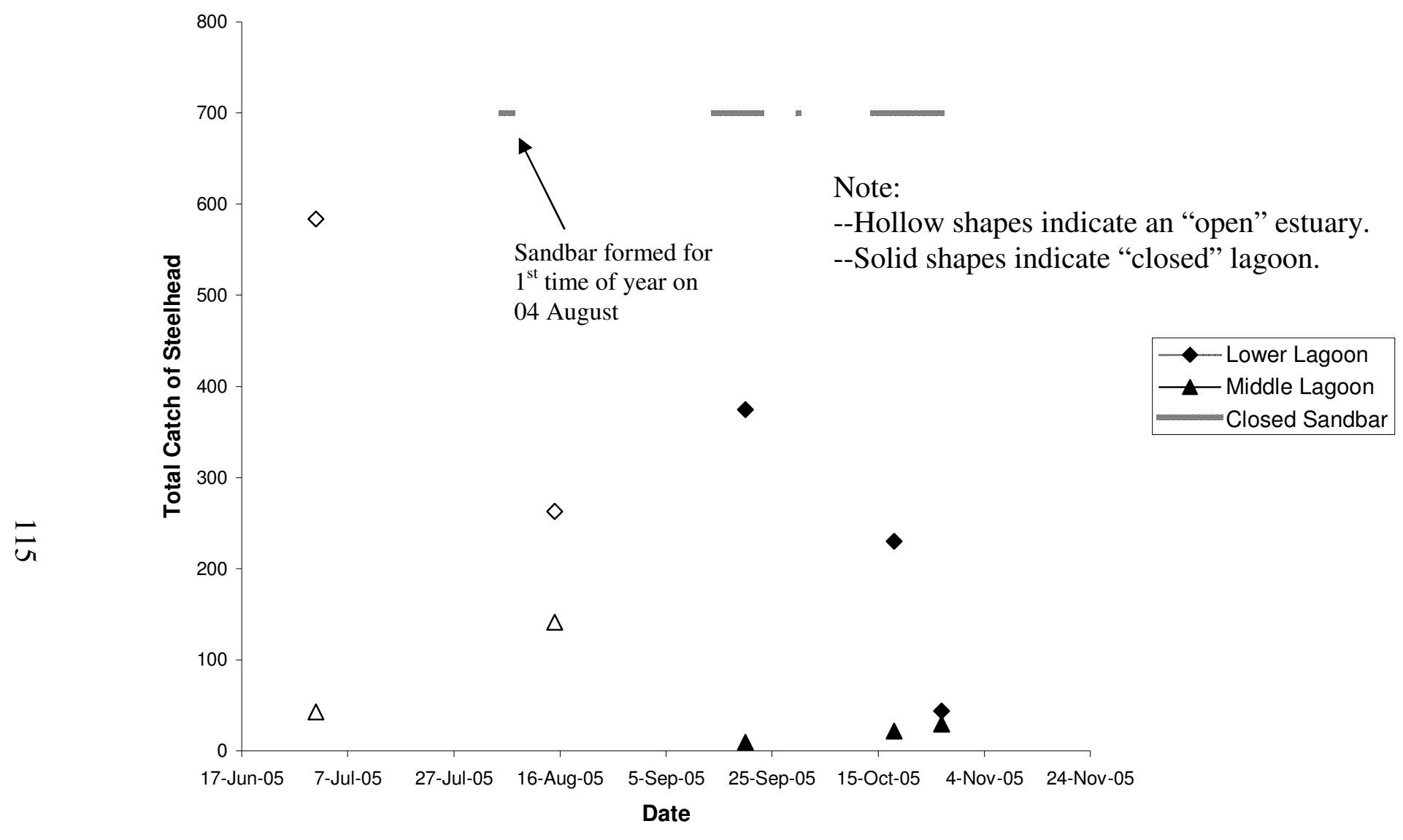

Figure 46. Total catch of steelhead, two seine hauls per station, from the period of July 01 to October 27, 2005 at stations located downstream ("Lower Lagoon") and upstream ("Middle Lagoon") within San Gregorio Creek lagoon, San Mateo County. For upstream sampling, the Middle Lagoon (I) Station was seined on July 01 and August 15 before it flooded with backwater caused by lagoon formation. After Middle Lagoon (I) Station flooded, Middle Lagoon (II) Station was seined (on September 20, October 18, and October 27, 2005) for upstream lagoon data. 


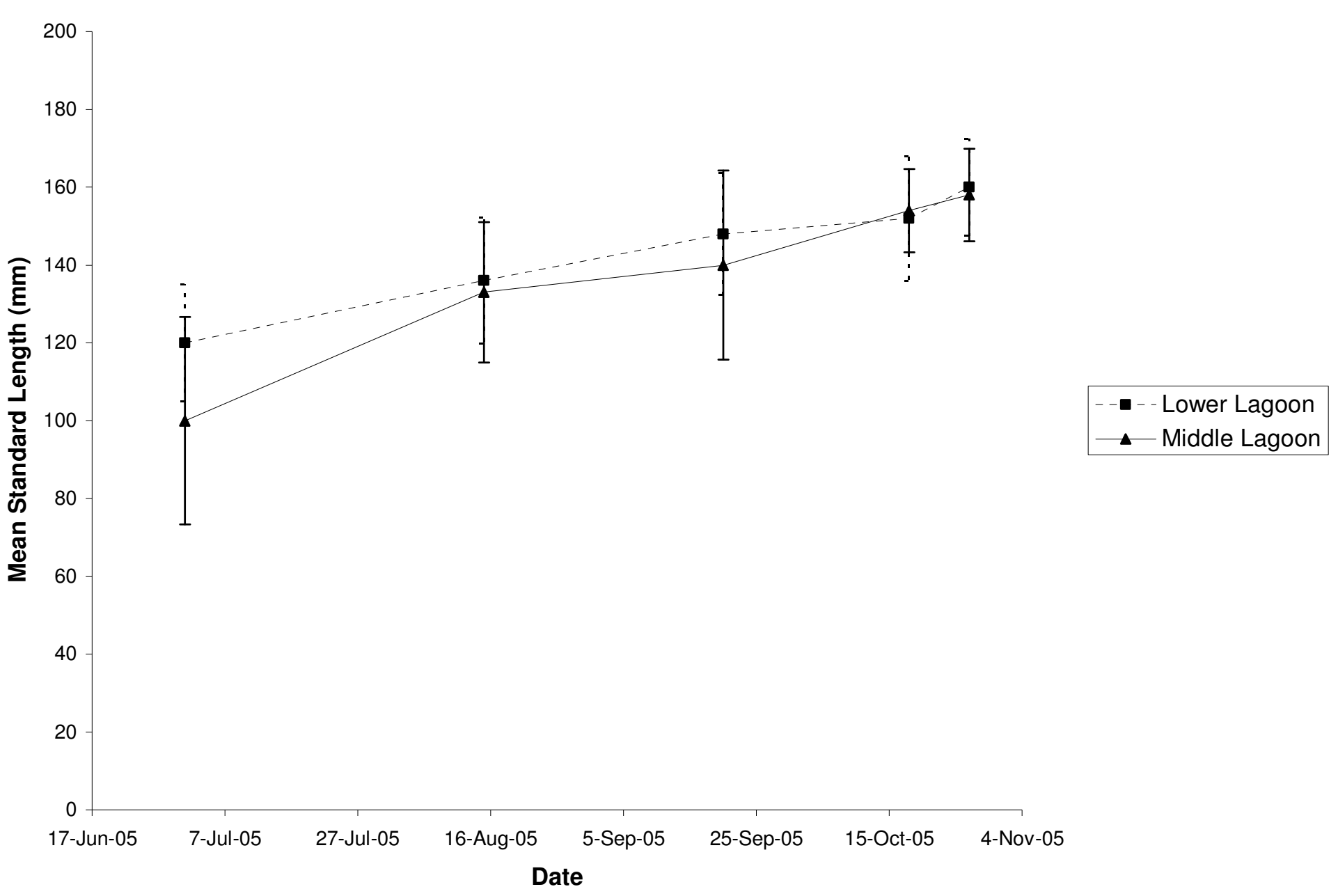

Figure 47. Mean standard lengths (mm) of total steelhead measured from the period of July 01 to October 27, 2005 in stations located downstream ("Lower Lagoon") and upstream ("Middle Lagoon") within San Gregorio Creek lagoon, San Mateo County. 
a)

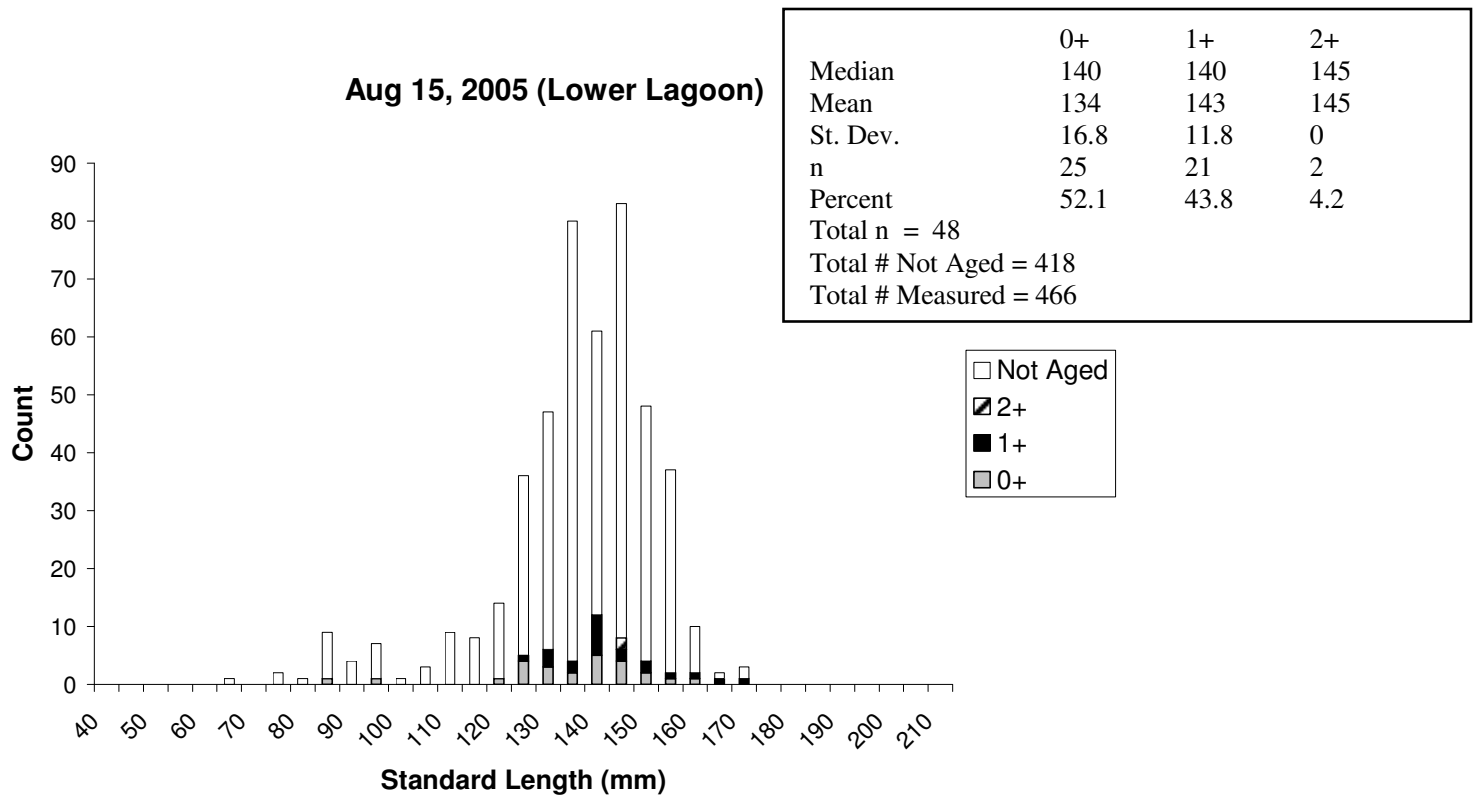

b)

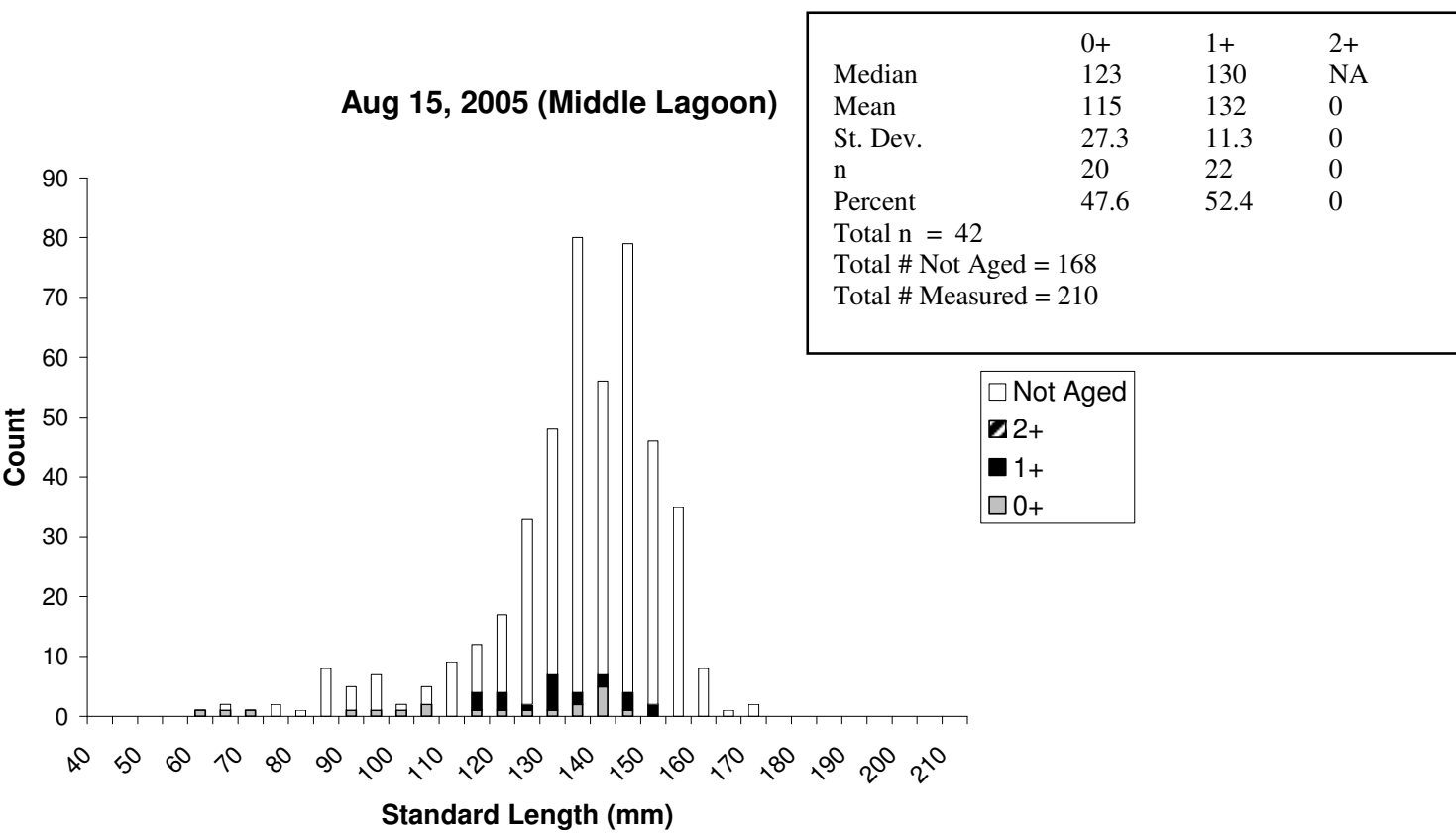

Figure 48. Standard length ( $\mathrm{mm}$ ) of steelhead of different ages at (a) downstream ("Lower Lagoon") and (b) upstream stations ("Middle Lagoon") on August 15, 2005 in San Gregorio Creek lagoon, San Mateo County. 
a)

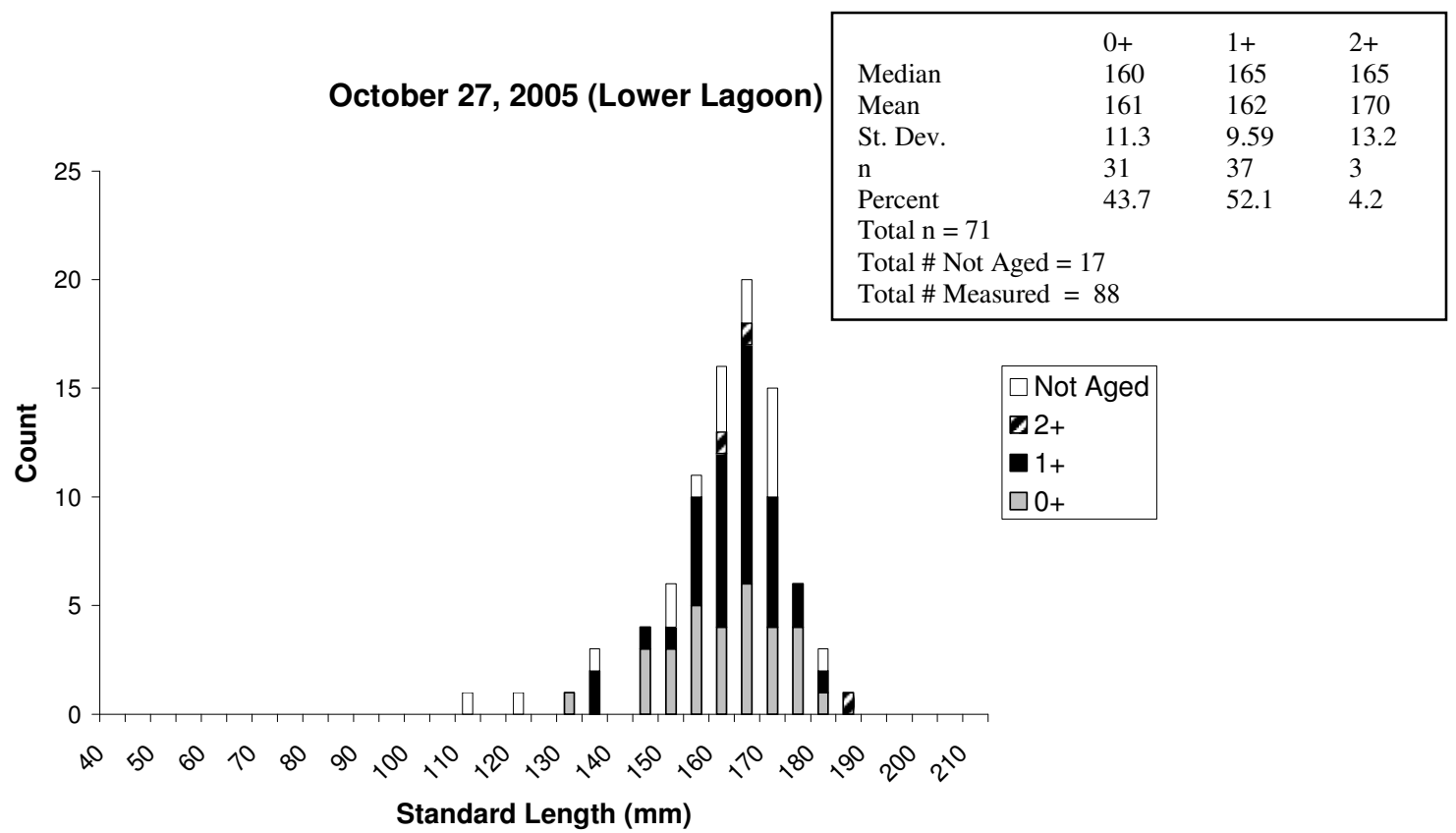

b)

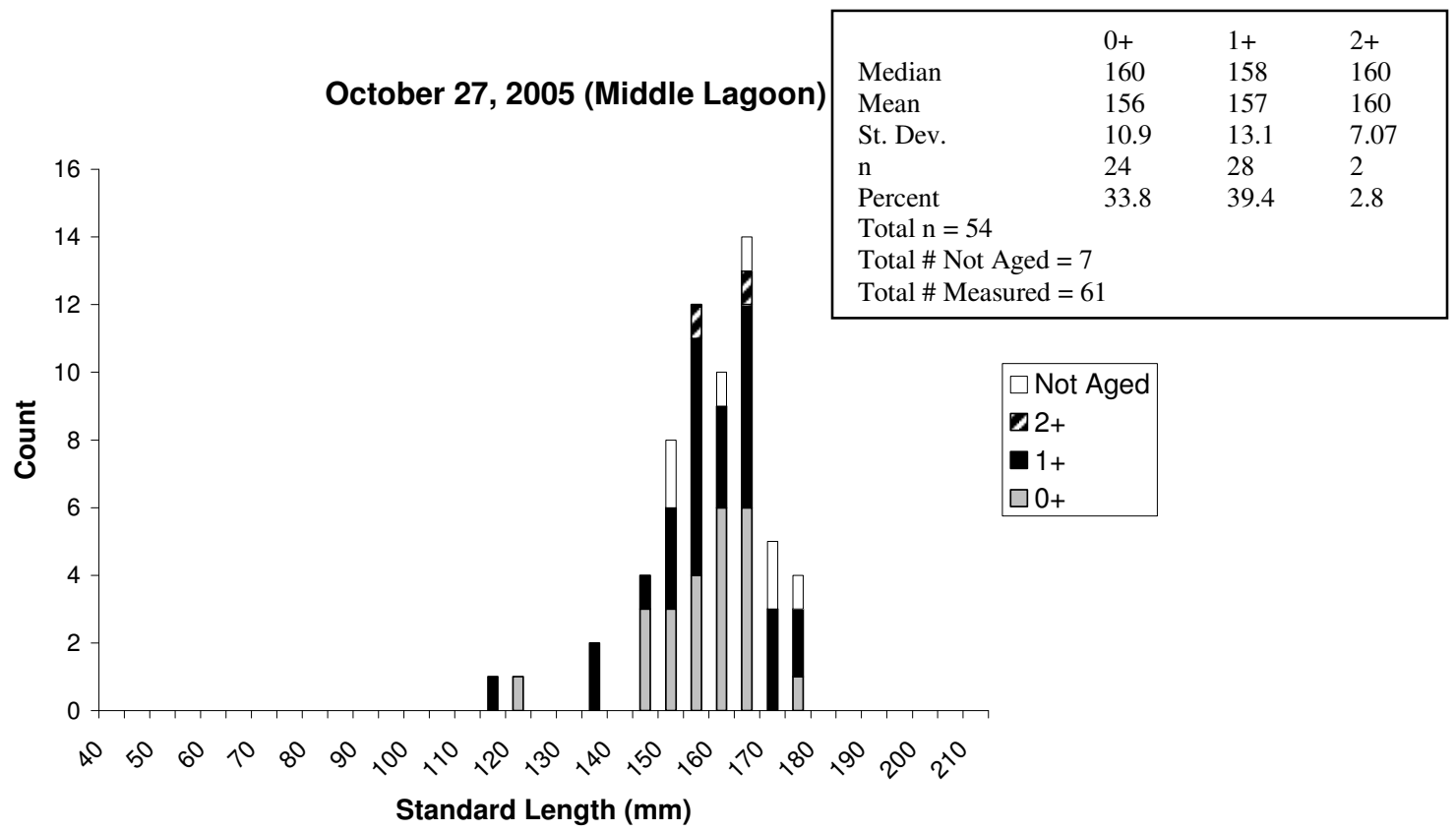

Figure 49. Standard length ( $\mathrm{mm}$ ) of steelhead of different ages at (a) downstream ("Lower Lagoon") and (b) upstream stations ("Middle Lagoon") on October 27, 2005 in San Gregorio Creek lagoon, San Mateo County. 